UNIVERSIDADE DE SÃO PAULO

FACULDADE DE FILOSOFIA, LETRAS E CIÊNCIAS HUMANAS

DEPARTAMENTO DE GEOGRAFIA

PROGRAMA DE PÓS-GRADUAÇÃO EM GEOGRAFIA FÍSICA

PAULO ROBERTO GAUDIO DE ALMEIDA

\title{
ANÁLISE DA LEGISLAÇÃO AMBIENTAL DE GUARULHOS APLICADA À OCUPAÇÃO DA MICROBACIA TAQUARA DO REINO
}

Versão Corrigida

São Paulo

2016 
UNIVERSIDADE DE SÃO PAULO

FACULDADE DE FILOSOFIA, LETRAS E CIÊNCIAS HUMANAS

DEPARTAMENTO DE GEOGRAFIA

PROGRAMA DE PÓS-GRADUAÇÃO EM GEOGRAFIA FÍSICA

PAULO ROBERTO GAUDIO DE ALMEIDA

\section{ANÁLISE DA LEGISLAÇÃO AMBIENTAL DE GUARULHOS APLICADA À OCUPAÇÃO DA MICROBACIA TAQUARA DO REINO}

Dissertação apresentada ao Programa de Pós-graduação em Geografia Física da Faculdade de Filosofia, Letras e Ciência Humanas da Universidade de São Paulo para obtenção do título de Mestre em Geografia.

Orientador: Prof. Dr. Antônio Carlos Colangelo

Versão Corrigida

De acordo:

Prof. Dr. Antônio Carlos Colangelo

São Paulo

2016 
ALMEIDA, P.R.G. Análise da legislação ambiental de Guarulhos aplicada à ocupação da microbacia Taquara do Reino: Dissertação de Mestrado apresentada junto ao Programa de Pós-Graduação em Geografia Física do Departamento de Geografia para obtenção do Título de Mestre em Geografia Física

Aprovado em:

\section{Banca examinadora}

Prof. Dr. Instituição:

Julgamento: Assinatura:

Prof. Dr. Instituição:

Julgamento: Assinatura:

Prof. Dr. Instituição:

Julgamento: Assinatura:

Prof. Dr. Instituição:

Julgamento: Assinatura:

Prof. Dr. Instituição: Julgamento: Assinatura: 


\section{Agradecimentos}

Torna-se difícil agradecer a todos que me ajudaram nesta jornada, mas gostaria de agradecer especialmente aos meus pais José e Rosana, às minhas irmãs Lilian e Natali, aos meus cunhados Ronaldo e Renan, meus queridos sobrinhos Letícia e Rafael e a todos os meu familiares, por todo o apoio e carinho.

Agradeço carinhosamente à minha companheira nas veredas da vida, minha querida Priscila, por todo o amor, amizade e compreensão.

À minha querida amiga Michelle, por todo apoio e ajuda, sem os quais não teria realizado tal empreitada. Aos queridos amigos Luiz, Martin e Marcel, por todo apoio e incentivo nos momentos mais difíceis. Ao grande amigo Yadyr Figueiredo Filho, por todo o incentivo e parceria ao longo dos projetos de pesquisa e por sua valiosa amizade.

Agradeço especialmente ao Professor Antonio Carlos Colangelo, pela honra concedida em ser meu orientador e pelos ensinamentos transmitidos.

Agradeço ainda aos amigos João Batista da Secretaria de Desenvolvimento Urbano de Guarulhos e Marcio Andrade do Centro Nacional de Monitoramento e Alertas de Desastres Naturais - CEMADEN - pela ajuda imprescindível e também aos técnicos e pesquisadores da Coordenação do Projeto de mapeamento das Áreas Suscetíveis, do Instituto de Pesquisas Tecnológicas - IPT - e do Serviço Geológico do Brasil - CPRM - por todo o apoio técnico e material concedido, sem os quais este trabalho não seria realizado.

Meus agradecimentos em especial aos funcionários da Secretária de PósGraduação e a Ana da copiadora, pela ajuda com os prazos e organização de todo o material a ser entregue.

Gostaria de registrar ainda meu imenso agradecimento aos amigos do IBGE e companheiros de labuta Thiago Pinheiro, Dagnaldo Rios, Benedito de Paula, Victor Kenzo, Pedro Krueger, Giorgio Menegatti e também ao colega Wagner da Silveira do SDI - Supervisão de Documentação e Disseminação de Informações - pelo apoio e suporte fundamentais para a conclusão deste trabalho.

Finalmente, agradeço à todos os professores, funcionários e colegas da Universidade de São Paulo pela colaboração ao longo de todos os anos de graduação e pós-graduação. 
How does it feel, how does it feel? To be without a home Like a complete unknown, like a rolling stone Bob Dylan - Like a Rolling Stone 


\section{Resumo}

ALMEIDA, P. R. G. Análise da legislação ambiental de Guarulhos aplicada à ocupação da Microbacia Taquara do Reino. 2016.

A presente dissertação buscou analisar a legislação de uso e ocupação do solo e as principais diretrizes de planejamento urbano e ambiental nas esferas federal, estadual e municipal através do estudo do Estatuto das Cidades, da Política Nacional de Proteção e Defesa Civil, do Plano Diretor Municipal bem como de legislação pertinente, e a aplicação dessas normatizações em uma área de risco de movimento de massa, produzindo um estudo de caso da microbacia Taquara do Reino, ocupada pelo loteamento do Recreio São Jorge e Novo Recreio, localizada no bairro do Cabuçu, no Município de Guarulhos.

Juntamente a esta análise, buscou-se apresentar um histórico da legislação federal e dos estudos da Geomorfologia voltados ao planejamento urbano e ambiental, bem como um breve histórico da criação do Município de Guarulhos e suas características econômicas, sociais e geográficas, abordando a dinâmica da expansão urbana ocorrida em função do crescimento da Região Metropolitana de São Paulo, com a finalidade de situar a ocupação da microbacia Taquara do Reino.

Palavras-chave: Planejamento urbano, Planejamento ambiental, Geomorfologia Ambiental, Áreas de risco, Movimento de massa, legislação ambiental, Microbacia Taquara do Reino, Uso e ocupação da terra, Município de Guarulhos, Recreio São Jorge. 


\section{Abstract}

This study aimed to analyze the use and occupation legislation and also the main guidelines of the urban and environmental planning observed by the federal, state and municipal spheres through the study of the Cities' Statute, the National Politics of Protection and the Civil Defense, the Municipal Directory Plan, as well as relevant legislation. The study also focused on the applications of these norms in an area of mass movement risk, producing a study case of the Taquara do Reino's watershed, occupied by the settlements of Recreio São Jorge and Novo Recreio, located at the Cabaçu neighborhood in Guarulhos County.

Together with this analysis, the study presented not only a history of the federal legislation and of the geomorphology studies regarding urban and environmental planning but also a brief history of the establishment of Guarulhos County and its economic, social and geographical features; addressing the dynamics of the urban expansion occurred as a result of the growth of Greater São Paulo in order to situate the occupation of Taquara do Reino's watershed.

Keywords: Urban planning, Environmental planning, Mass movement risk, Land use and occupation, Environmental Geomorphology, Guarulhos County, Taquara do Reino's watershed. 


\section{Sumário}

Introdução

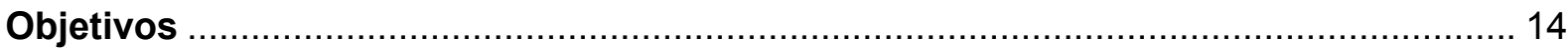

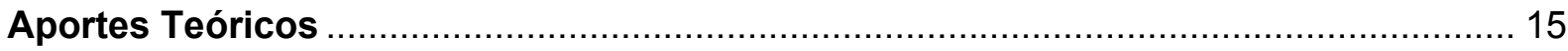

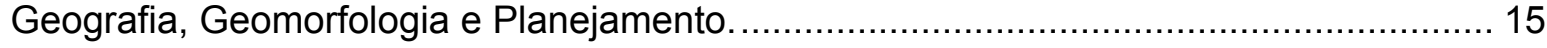

O Desenvolvimento da ciência geomorfológica ...................................................... 15

Geomorfologia e suas contribuições para o planejamento urbano-ambiental ............... 19

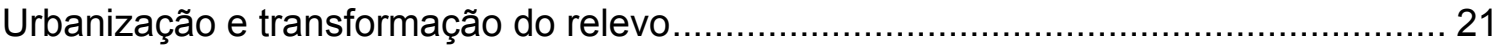

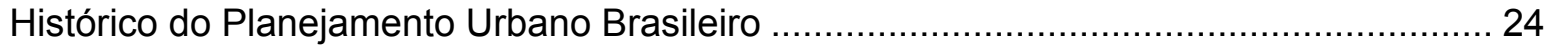

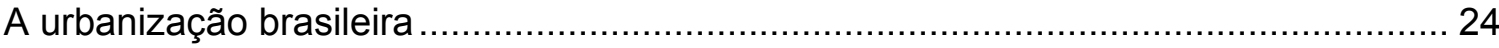

Plano Diretor e Política Nacional de Proteção e Defesa Civil ......................................... 32

A Política Nacional de Proteção e Defesa Civil ............................................................ 35

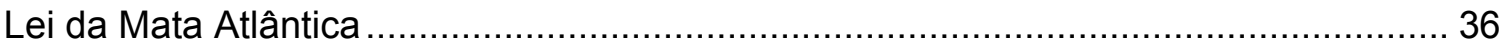

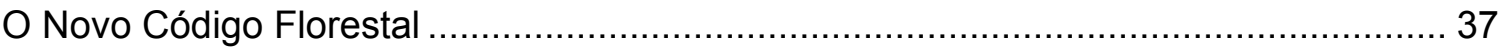

Localização e descrição da área de estudo .......................................................... 40

Características do Município de Guarulhos .............................................................. 41

Colonização e exploração aurífera - Breve histórico do Município de Guarulhos .......... 41

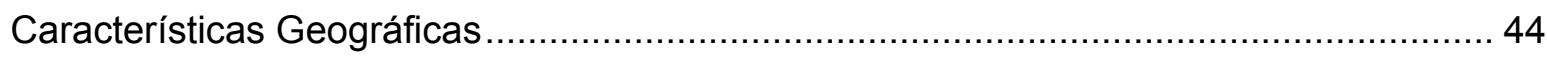

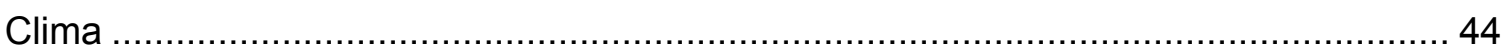

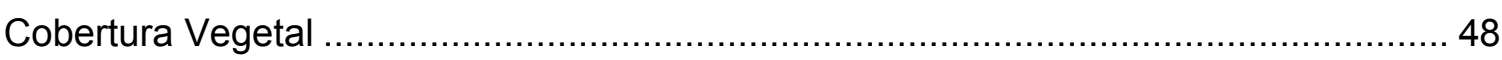

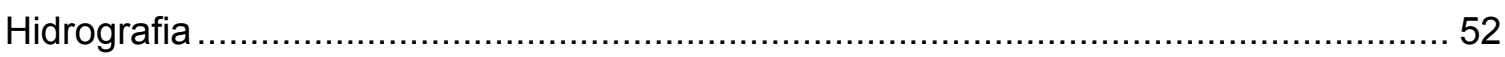

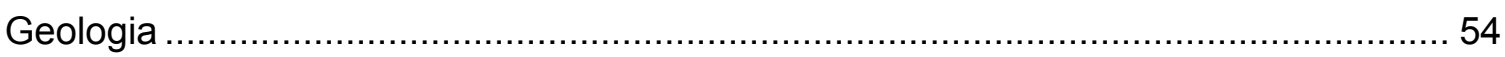

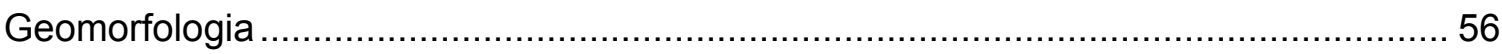

Planejamento Ambiental e Urbano e a Legislação Municipal de Guarulhos ................ 64

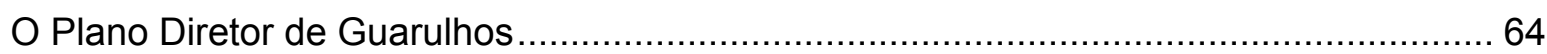

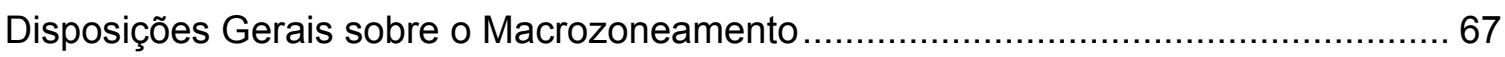

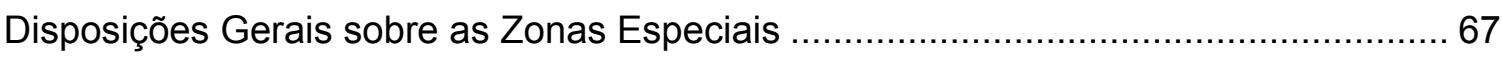

Meio Ambiente e Planejamento Ambiental................................................................ 68

Lei de Uso e Ocupação do Solo do Município de Guarulhos ........................................ 70

Lei De Criação Da Área De Proteção Ambiental Cabuçu - Tanque Grande...................... 72

Plano Municipal de Redução de Riscos e as ações municipais ..................................... 74

Características geomorfológicas da Microbacia Taquara do Reino. ................................. 77

Características socioeconômicas da microbacia Taquara do Reino ................................... 80

Usos e restrições na Bacia Taquara do Reino .................................................................. 84

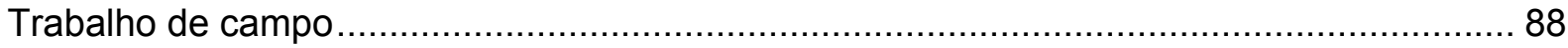


Discussão 94

Bibliografia. 98

Anexo 1. Zona especial de proteção e desenvolvimento sustentável - ZPDS - 2 106 


\section{Índice de Mapas}

Mapa 1. Região Metropolitana de São Paulo - RMSP - Município de Guarulhos Microbacia Taquara do Reino.

Mapa 2. Mineração de ouro - Início da expansão urbana da Cidade de Guarulhos. ............ 42

Mapa 3. Evolução urbana do município de Guarulhos.................................................... 43

Mapa 4. Classificação do clima do Estado de São Paulo pelo sistema internacional de

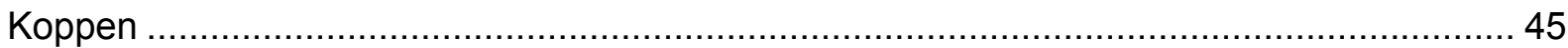

Mapa 5. Precipitações médias anuais e mensais. Fonte: IPT/CPRM, 2014 ...................... 47

Mapa 6. Cobertura Vegetal do Município de Guarulhos............................................... 50

Mapa 7. Unidades de Conservação de Guarulhos.............................................................. 51

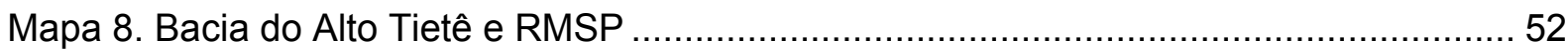

Mapa 9. Bacias e Sub-bacias Hidrográficas do Município de Guarulhos ............................. 53

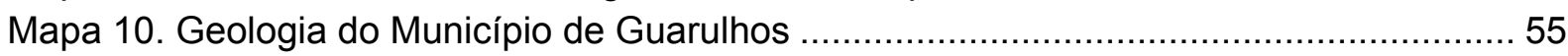

Mapa 11. Padrões de Relevo do Município de Guarulhos ................................................. 58

Mapa 12. Recorte do Mapa Geomorfológico do Parque Estadual da Cantareira e APA do

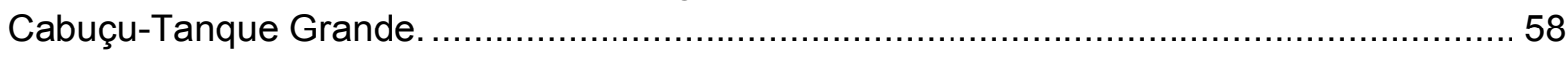

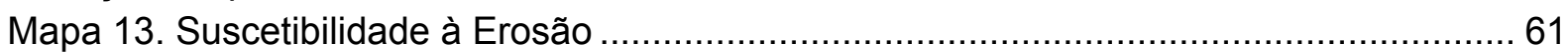

Mapa 14. Áreas Sujeitas a Processos Erosivos .......................................................... 62

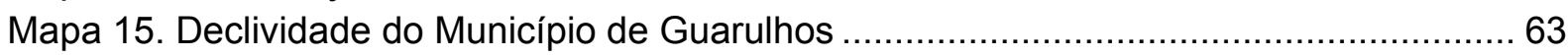

Mapa 16. Mapa Hipsométrico da Microbacia Taquara do Reino.......................................... 78

Mapa 17. Mapa Clinográfico Microbacia Taquara do Reino............................................... 79

Mapa 18. Mapa de Unidades Geoambientais Microbacia Taquara do Reino ....................... 79

Mapa 19. Uso do Solo e Zonas de Restrição de Uso Microbacia Taquara do Reino ........... 86

Mapa 20. Mancha urbana e zonas de restrição de uso Microbacia Taquara do Reino ........ 87

\section{Índice de Tabelas}

Tabela 1. Características geomorfológicas dos Planaltos e Serras do Atlântico Leste-

Sudeste.

Tabela 2. Sistemas de relevo e respectivas características morfométricas e morfográficas das folhas Guarulhos e Itaquaquecetuba 59

Tabela 3 - Critérios para definição do grau de probabilidade de ocorrência de processos de instabilização do tipo escorregamentos em encostas ocupadas e solapamento de margens de córregos 74

Tabela 4. Tipos de intervenção para as áreas de risco mapeadas pelo PMRR .................... 75 


\section{Índice de Gráficos}

Gráfico 1. Climograma Comparativos Guarulhos, Santos, Ribeirão Preto e Ubatuba .......... 46

Gráfico 2. Climograma do período entre 1985 e 2008................................................... 47

Gráfico 3. Pirâmide etária microbacia Taquara do Reino - Censo 2010 .............................. 81

Gráfico 4. Condições Gerais de Saneamento Básico na microbacia Taquara do Reino. ..... 82

Gráfico 5. Gênero dos Responsáveis Por Domicílios Segundo Situação Geomorfológica... 83

Gráfico 6. Domicílios com responsável sem rendimento nominal e restrição de ocupação.. 83

Gráfico 7. Taxa de alfabetização de responsável por domicílio por gênero, de acordo com situação geomorfológica do setor.

\section{Índice de Quadros}

Quadro 1. População Residente por situação do domicílio - 1940 - 2010

\section{Índice de Imagens}

Imagem 1. Evolução da ocupação da Microbacia Taquara do Reino ................................. 80

Imagem 2. Ocupação em vertente em anfiteatro............................................................ 88

Imagem 3. Ocupação de vertente de alta declividade .................................................... 89

Imagem 4. Casas em risco de colapso...................................................................... 89

Imagem 5. Ruas perpendiculares ao talvegue do vale na microbacia Taquara do Reino. ... 90

Imagem 6. Casa em risco de colapso na microbacia Taquara do Reino .............................90

Imagem 7. Rua e casas em risco de colapso na microbacia Taquara do Reino.................... 91

Imagem 8. Muro em risco de colapso na microbacia Taquara do Reino ............................. 91

Imagem 9. Escorregamento em vertente da microbacia Taquara do Reino. ........................ 92

Imagem 10. Escorregamento em vertente da microbacia Taquara do Reino ...................... 92

Imagem 11. Rua pavimentada com bloquetes de cimento na microbacia Taquara do Reino

Imagem 12. Descarte de lixo em encosta na microbacia Taquara do Reino. ....................... 93 


\section{Introdução}

Entender as relações entre a sociedade e a natureza que produzem os diferentes espaços urbanos exige profunda compreensão de diversas áreas do conhecimento. Existem inúmeras dinâmicas que atuam nas relações entre as populações e as formas pelas quais estas se apropriam dos lugares como sua morada. Nem sempre essas relações são harmônicas, seja devido às características naturais do local a ser povoado, seja em relação às legislações estabelecidas pelo poder público. Dessa maneira, as populações mais pobres acabam por ocupar locais pouco adequados à fixação humana, dando origem a áreas carentes de infraestrutura, insalubres e que geralmente apresentam risco à vida.

Com o crescimento das cidades e a ocupação de diversas partes do território, algumas das grandes preocupações atuais são as inundações e os escorregamentos de encostas que, segundo Carvalho e Galvão (2006), são os principais fenômenos ligados a desastres naturais ${ }^{1}$ no Brasil, associados a longos e intensos eventos de chuva. Como referência, segundo a Base de Dados Global de Eventos de Emergência - EM-DAT (Emergency Events Database) no Brasil registraram-se 150 desastres durante o período 1900-2006 (MARCELINO, 2008)

Segundo Marcelino (2008, pg 144), os desastres de maior frequência são as enchentes/inundações, com aproximadamente $59 \%$ dos registros, e os escorregamentos, com 14\%. Para os desastres do período 1900-2006, estimam-se 8.183 vítimas fatais e um prejuízo de aproximadamente 10 bilhões de dólares Sobre a distribuição espacial, mais de $60 \%$ dos casos ocorreram nas regiões Sul e Sudeste. Essa distribuição está mais associada às características geoambientais do que às socioeconômicas. E embora as inundações tragam maiores prejuízos econômicos e materiais, os deslizamentos trazem o maior número de vítimas fatais. Em uma análise acerca das ocorrências no Estado de São Paulo, nos períodos de verão entre os anos de 2004 e 2008, a Defesa Civil registrou mais de 48.433 vítimas de inundações e escorregamentos, sendo 144 feridos e 96 mortes (BUSTAMANTE, 2010).

\footnotetext{
${ }^{1}$ Tais como enchentes, deslizamentos, vendavais, tornados, chuvas de granizo de alto poder destrutivo, incêndios florestais, ressacas marítimas, etc. O conceito de desastre natural será abordado adiante.
} 
Os escorregamentos podem ocorrer naturalmente a qualquer momento e em qualquer área de declividade mais acentuada, principalmente devido a períodos mais longos e intensos de pluviosidade. Porém, a retirada da cobertura vegetal e as atividades antrópicas irregulares (tais como cortes mal planejados em encostas, escavações irregulares, uso incompatível com as características locais, etc.) podem agravar o quadro de vulnerabilidade e suscetibilidade a movimentos gravitacionais de massa em uma área, acelerando os processos naturais e fazendo com que áreas antes estáveis tornem-se instáveis para a ocupação humana.

De acordo com Carvalho e Galvão (2006), os desastres relacionados a deslizamentos com vítimas, nas duas últimas décadas, foram concentrados em apenas 150 municípios brasileiros. A quase totalidade destes casos foi registrada nos estados de São Paulo, Rio de janeiro, Minas Gerais, Santa Catarina, Pernambuco, Alagoas, Bahia e Espírito Santo, o que demonstra que os casos têm maior ocorrência nas áreas mais densamente povoadas e urbanizadas do país e, principalmente, no domínio dos Planaltos e Serras do Atlântico Leste-Sudeste.

Embora os serviços de prevenção de desastres naturais, bem como a avaliação das áreas de risco e fragilidade ambiental tenham sido uma atribuição dos governos municipais, em face da insuficiência dessas ações, no ano de 2006 o governo federal criou o Programa de "Apoio à prevenção e erradicação de riscos em assentamentos precários", dentro do projeto de "Urbanização, regularização e integração de assentamentos precários" (MINISTÉRIO DAS CIDADES, 2010). Neste programa, o governo federal visa assessorar os municípios no planejamento e redução de casos de escorregamentos em encostas, erosão e enxurradas.

Dessa maneira, inúmeras áreas periféricas das grandes cidades brasileiras tornaram-se objeto do planejamento público, havendo projeto de regulamentação para a ocupação do solo urbano e tentativa de regularização de áreas já construídas. Dentre as legislações aprovadas pelo poder público, podemos destacar a lei $\mathrm{n}^{\circ}$ 10.257/2001 (Estatuto da Cidade) e a lei n 12.608/2012 (Política Nacional de Proteção e Defesa Civil), estabelecidas na esfera federal e que servem como base legal e diretriz central para a criação das legislações estaduais e municipais.

Na prática, os planos diretores passaram a determinar a maneira pela qual cada área do município deveria ser ocupada e por qual tipo de atividade. Tornou-se, 
portanto, indispensável o uso de diversos estudos integrados para melhor adequar os usos e ocupações do solo, principalmente no que diz respeito aos estudos geomorfológicos, englobando técnicas modernas de mapeamento e modelagem na prevenção dos riscos ambientais.

A Geografia, através da Geomorfologia, tenta compreender, explicar e estabelecer formas de planejamento, uso e ocupação das mais variadas porções do espaço geográfico, seja em áreas mais densamente povoadas e urbanizadas, seja em áreas que ainda preservam características naturais ainda pouco antropizadas e dessa forma, compreendendo as interações entre a sociedade e a natureza, mais especificamente em relação à superfície terrestre e os seus diversos modos de apropriação e transformação.

Para a melhor compreensão dos processos e fenômenos que caracterizam as áreas de risco de desastres naturais se torna necessário antes fazer uma análise de como se desenvolveu o planejamento das cidades ao longo de nossa História, as legislações e seus objetivos, bem como da participação da Geomorfologia no planejamento ambiental, entendida como área de estudo da ciência geográfica que leva sempre em consideração as interações entre a sociedade e a natureza ao longo do tempo.

\section{Objetivos}

O objetivo deste trabalho consiste em analisar a aplicação das políticas públicas de planejamento e sua legislação em uma microbacia ocupada por um loteamento, cuja estrutura gemorfológica e o uso e ocupação da terra favorecem as dinâmicas de risco de movimentos de massa. Como estudo de caso foi analisada microbacia Taquara do Reino, bairro do Cabuçu, no município de Guarulhos. 


\section{Aportes Teóricos}

\section{Geografia, Geomorfologia e Planejamento.}

O Desenvolvimento da ciência geomorfológica

A ciência geomorfológica teve seu início através de estudo geológicos da crosta terrestre em meados do século XVIII, estando vinculada a geografia e a geologia, desenvolvendo assim um enfoque de tendência naturalista, acabou por se voltar aos interesses do sistema de produção, com base no utilitarismo.

Segundo Abreu (1982) e Casseti (1994, 2007) apud Florenzano (2008), sobre essa época, merecem destaque as contribuições de A. Surell, com o esquema clássico da erosão torrencial; Jean Louis Agassiz, que trouxe as bases da morfologia glacial; W. Jukes, responsável pelos primeiros conceitos sobre os cursos fluviais; Andrew Ramsay e Grove Karl Gilbert, com as evidências da capacidade de aplainamento das águas correntes; e John Wesley Powell e Clarence E. Dutton com os cálculos de arraste e deposição de sedimentos.

Após a realização dos estudos de Powell (1875), Gilbert (1877) e Davis (1899) apud Florenzano (2008), o final do século XIX é mercado pelo início da sistematização da ciência geomorfológica. A partir de então, a Geomorfologia surge como uma ciência fundamentada no conceito de ciclo (Geographical Cycle) e na teoria do evolucionismo a partir das ideias de Charles Darwin, tendo a teoria de Davis como vanguardista desta proposta (FLORENZANO, 2008).

Para Davis, dentro de sua teoria do Ciclo Geográfico, o relevo é resultante das relações entre a estrutura geológica, os processos atuantes e o tempo, sendo que no início do ciclo, as forças internas levariam a um rápido soerguimento das superfícies aplainadas, gerando grandes elevações com relação ao nível do mar. O processo erosivo causado pela água corrente dissecaria e rebaixaria o relevo, formando uma superfície aplainada denominada de peneplano. A partir dessa base plana, um novo processo de soerguimento daria início a um novo ciclo e assim sucessivamente. Dessa maneira, portanto, o ciclo do relevo seria caracterizado por fases, chamadas de juventude, maturidade e senilidade. Embora tenha sido a base da escola angloamericana até meados do século $\mathrm{XX}$, a teoria de Davis sofreu profundas críticas por considerar uma grande estabilidade tectônica em seu modelo. 
No caminho oposto as ideias de Davis, a escola geomorfológica alemã, liderada por Albrecht Penck (1849 apud ABREU, 1982) e Walther Penck (1924 apud ABREU, 1982) defendia a concepção de que a superfície terrestre é formada por elementos integrados, valorizando assim o estudo dos processos através da articulação de suas ideias com a Climatologia e a Biogeografia, o que levou ao desenvolvimento do conceito dos depósitos correlativos. De acordo com os estudos alemães, a emersão (soerguimento) e a denudação (desgaste) ocorrem ao mesmo tempo e quando o processo de entalhamento dos vales é mais intenso que o da denudação, ocorre o predomínio de vertentes convexas na superfície terrestre; quando o entalhamento tem a mesma intensidade da denudação, ocorre o predomínio de vertentes retilíneas; porém, quando o entalhamento é menos intenso que a denudação, ocorre o predomínio de vertentes côncavas na superfície terrestre.

Segundo Florenzano (2008), ainda podemos destacar dentro da escola alemã as contribuições de Sigfried Passarge (1913), que trouxe o conceito de paisagem para a geomorfologia e de Troll (1932), que criou o conceito de geoecologia. Após a Segunda Guerra Mundial surgiu ainda a cartografia geomorfológica como método para a análise do relevo, a partir das contribuições da escola polonesa, da antiga Tchecoslováquia e da ex-URSS (KLIMASZEWSKI, 1982; DEMEK, 1972; BASENINA e TRESCOV, 1972 apud FLORENZANO, 2008).

Baseados nos estudos de Walther Penck (1953), King (1955) e Pugh (1955) também da escola anglo-americana admitiram a possibilidade de que os soerguimentos podem ocorrer em períodos rápidos e intermitentes, separados por longos períodos de estabilidade tectônica, com o predomínio da denudação ocorrendo ao mesmo tempo em que o soerguimento ocorria. Esses autores desenvolveram a teoria da pediplanação (a partir do conceito de recuo de vertentes estabelecido por Penck) que basicamente consiste no processo de formação de pediplanos, isto é, de superfícies aplainadas que podem apresentar, em sua área de abrangência, formas residuais ainda não aplainadas, denominadas de inselbergs. (FLORENZANO, 2008).

A partir da década de 1960, as abordagens quantitativas e a teoria dos sistemas e fluxos passam a ter uma influência maior no estudos geomorfológicos, principalmente através dos primeiros usos de computadores. Nesse período, os trabalhos de Strahler (1954), Horton (1945) e Gregory e Wailing (1973) apud 
Florenzano (2008) sobre as bacias de drenagem ganham maior destaque. No ano de 1960, Hack traz o conceito de "equilíbrio dinâmico" e da consideração do relevo como um sistema aberto que está constantemente trocando energia e matéria com os demais sistemas terrestres, tomando o relevo como um produto da resistência litológica à ação dos agentes erosivos, deixando para trás a ideia do relevo cíclico e passando a considerar as mudanças climáticas.

Contudo, a partir do surgimento da Teoria Geológica da Tectônica de Placas, ainda na década de 1960, foi possível aprimorar a compreensão da morfogênese do relevo. Segundo esta teoria, as placas tectônicas que forma a crosta terrestre seriam fragmentadas e se moveriam em diferentes direções e velocidades. Estes movimentos, por sua vez, causariam instabilidade nas bordas das placas, sendo estas áreas o local de ocorrência de atividades vulcânicas, sísmicas e tectônicas. Essas atividades fazem parte dos processos endógenos, que ocorrem a partir dos movimentos internos do manto terrestre e que, ao serem associadas aos processos exógenos (precipitações atmosféricas, ventos, umidade, atividade biológica, etc.) são responsáveis pela esculturação, isto é, pela modelagem das formas do relevo na superfície terrestre.

Outra escola de bastante destaque na geomorfologia é a francesa, tendo como seus principais representantes Emmanuel de Martonne e Jean Tricart. Criada a partir do modelo americano, a escola francesa marcou o desenvolvimento da Geografia e da Geomorfologia no Brasil, tendo Martonne (1964) como expoente das ideias de Davis, na linha da geomorfologia estrutural e com Tricart (1977) que criou o conceito de ecodinâmica, baseado no balanço morfogênese/pedogênese. Essa modalidade de abordagem se baseia nas teorias de Troll (1932), com seu conceito de paisagem ecológica, que trouxe a ideia da interpretação de fotografias aéreas para o mapeamento de unidades de paisagem. Nesta mesma linha, podemos citar as contribuições de Bertrand (1972), de Sotchava (1977) com o conceito de geossistema e de Tricart e Klink (1979) com o conceito de ecogeografia.

No que diz respeito ao Brasil, Ab'Saber (1969) foi quem trouxe a maior contribuição à teoria geomorfológica, baseando-se na escola germânica. Segundo Ab'Saber, podemos analisar o relevo a partir de três níveis de abordagem, sendo eles: 
1 - Compartimentação topográfica regional e caracterização morfológica: realiza a análise de diferentes níveis topográficos e das características do relevo, com destaque para a morfologia;

2 - Estrutura superficial da paisagem: estabelece a relação entre os depósitos correlativos e as condições climáticas com ênfase na morfogênese;

3 - Processos morfoclimáticos e pedogênicos atuais e fisiologia da paisagem: efetua a análise dos processos atuais e a morfodinâmica, considerando o homem como um dos agentes desses processos.

A compartimentação do relevo proposta por Ross (1992) propõe a classificação do relevo em seis níveis taxonômicos², baseando-se na gênese e na morfologia. Contudo, segundo Abreu (1982), os trabalhos de Ab'Saber possuem maior flexibilidade para se ajustar à essência dos fatos verificados, seja do ponto de vista espacial ou temporal, valorizando a perspectiva geográfica. Atualmente, Casseti (2007) tem retomado essas ideias utilizando o conceito de "natureza externalizada", segundo Florenzano (2008, p. 27) como:

[...] argumento de apropriação espontânea do relevo e propõe, com base nos subsídios oferecidos pela "geomorfologia funcional", alternativa para o desenvolvimento de uma "geomorfologia integral" (Casseti, 1991) conforme conceituação de Hamelin (1964).

No ano de 2002, Ab'Saber lançou o conceito de "espaço total", segundo o qual:

O espaço total é o arranjo e o perfil adquiridos por uma determinada área em função da organização humana que lhe foi imposta ao longo dos tempos. (...) inclui todo o mosaico dos componentes introduzidos pelo homem, ao longo da história, na paisagem de uma área considerada parte de um determinado território. O termo paisagem é usado aqui como suporte geoecológico e bioecológico modificado por uma infinidade variável de obras e atividades humanas. (AB'SABER, et al 2002, p.30)

Atualmente, possuem destaque os trabalhos de Christofoletti (1980) que traz a luz conceitos sobre a teoria dos sistemas e a geomorfologia dinâmica e de Colângelo (1989) que aborda o conceito de feições mínimas do relevo.

\footnotetext{
${ }^{2}$ Ross (1992) estabeleceu a classificação do relevo a partir de seis "táxons", sendo eles respectivamente: as Unidades Morfoestruturais; as Unidades Morfoesculturais; as Unidades Morfológicas ou Padrões de Formas Semelhantes; as Formas Individualizadas; os Setores das Vertentes; e as Pequenas Formas de Relevo.
} 
Geomorfologia e suas contribuições para o planejamento urbano-ambiental

Sendo a Geomorfologia a área da Geografia que trata das formas do relevo terrestre, por consequência, ela estuda os materiais e processos que deram origem a essas formas, ou seja, os processos geomorfológicos. Devido à variedade de suas formas e materiais componentes, a superfície terrestre pode oferecer os mais variados ambientes para a fixação das sociedades humanas, que pode ocorrer em áreas mais adequadas a ocupação e a construção das habitações ou também pode ocorrer em áreas pouco favoráveis à ocupação, podendo gerar resultados desastrosos com danos ambientais e prejuízos materiais para as sociedades, bem como a perda de vidas humanas e danos aos ecossistemas.

Dessa maneira, os conhecimentos proporcionados pelos estudos da Geomorfologia associados aos conhecimentos da Pedologia podem fornecer importantes contribuições para o diagnóstico de áreas degradadas e também dar apoio ao planejamento ambiental e urbano. Assim, para Guerra et al (2014) a ciência geomorfológica "procura compreender as formas de relevo em diferentes escalas espaciais e temporais, explicando não só a sua gênese, mas também como evoluem no tempo e no espaço". Cabe então ao geomorfólogo a compreensão da combinação entre os diversos processos que ocorrem no interior do planeta (forças endógenas) e os processos externos (forças exógenas) que ocorrem na atmosfera, visto que a ação do ser humano tende geralmente a acelerar estes processos, levando a instabilidade e ao desequilíbrio das combinações e gerando danos ambientais e sociais.

O estudo das formas de relevo é de extrema importância para a compreensão dos fenômenos correlatos e das consequências que as interferências antrópicas podem causar, visto que cada sistema físico apresenta características singulares e assim tem respostas diferenciadas frente as diversas modalidades de intervenção humana.

Conforme salientou Rodrigues (2010), as transformações nos processos podem ser monitoradas historicamente se considerarmos a sequência de intervenções e seus prováveis efeitos "em sistemas geomorfológicos como vertentes, canais e planícies fluviais baseados em indicadores".

Ainda de acordo com Rodrigues (2010): 
[...] a consideração das ações antrópicas potencialmente modificadoras do equilíbrio dinâmico desses sistemas torna-se fundamental, principalmente para o meio tropical úmido, em que mudanças no tipo de cobertura superficial implicarão radical ruptura nos balanços de processos originais. Embora devam ser considerados todos os fatores que controlam a morfodinâmica de vertentes, sobretudo os que condicionam a intensidade de processos erosivos, tais como a tectônica, litologia, erosividade das chuvas, erodibilidade dos solos, cobertura vegetal, morfometria (declividades, extensão, orientação etc.) e morfologia - acredita-se que este último foi pouco considerado ou explorado. (Rodrigues e Gouveia, 2014, p. 70)

Dessa maneira, conclui-se que ao modificar as estruturas originais dos sistemas naturais, teremos não apenas os processos que ocorreriam naturalmente de acordo com a combinação de fatores que ali existiam mas também a introdução de novos processos e parâmetros criados devido a intervenção antrópica, devendo somar-se aos anteriores.

Nesse sentido, o conceito de geossistema, introduzido por Sotchava em 1962, (evocando o conceito de sistema introduzido por Chorley no mesmo ano) trouxe uma grande contribuição para os estudos da geomorfologia ambiental, consistindo basicamente na combinação dos fatores geomorfológicos, climáticos, hidrológicos e da cobertura vegetal, associados aos fatores sociais e econômicos, podendo assim gerar unidades homogêneas ou heterogêneas. Para Christofoletti (1991) o geossistema é composto por elementos topográficos, biogeográficos e pedológicos integrados aos fluxos climáticos e submetidos às ações antrópicas que se tornam parte ativa na caracterização e na dinâmica do ambiente.

Para diversos autores (Bertrand, 1971; Tricart, 1977; Bolós, 1981; Rougerie e Beroutchachvili, 1991; Christofoletti, 1999, etc.) a visão geossistêmica seria a principal abordagem metodológica para os estudos da Geografia Física, tendo o geossistema como o conjunto de fenômenos naturais englobando também os fatores econômicos e sociais, correspondendo juntos à paisagem modificada (GUERRA e MARÇAL, 2006). De acordo com estes autores, a Geografia Física é caracterizada como uma ciência de síntese e integração, pois agrega o ser humano e suas atividades nas análises das características físicas da natureza.

Para efeito de melhor compreensão, Guerra e Marçal (2006) destacam que segundo Gondolo (1999) e Camargo (1999), a questão ambiental deve ser abordada dentro de uma ótica holística, na qual o todo se comporta diferente de suas partes ou do simples somatório do comportamento das partes. Para Gondolo (1999), a 
complexidade do comportamento da natureza implica em uma não-linearidade, ou seja, a mudança de comportamento do sistema pode resultar em múltiplas e complexas respostas. A autora ainda destaca que a evolução do sistema não ocorre aleatoriamente, visto que este obedece a determinadas leis e formas de comportamento, permitindo a compreensão da dinâmica da natureza, cujo resultado será em "transformação, auto-organização, dissipação e novamente organização" (GUERRA e MARÇAL, p. 98, 2006).

Segundo Ross (2003 apud GUERRA e MARÇAL, 2006), os estudos ambientais demandam o conhecimento dos aspectos físicos e, sendo um dos ramos específicos da Geografia Física, a Geomorfologia tem as formas de relevo e os processos que contribuíram para sua origem e evolução como seu objeto de estudo, permitindo assim a construção de metodologias específicas para análises ambientais. Para o autor, as relações entre o homem e o meio ambiente sempre estiveram presentes nos estudos geográficos, dando um suporte satisfatório para a elaboração de Zoneamentos Ambientais e Socioeconômicos bem como para as políticas de gerenciamento e planejamento ambiental no âmbito governamental. A importância da Geomorfologia nestes estudos é representada através da "elaboração de mapas, gráficos e tabelas que fornecerão informações socioeconômicas, podendo ser representados por processos informatizados ou não."

Ainda segundo Guerra e Marçal (2006), Cooke et al (1985) declaram que a Geomorfologia pode contribuir para um desenvolvimento urbano sem maiores danos ambientais que coloquem a vida da população das cidades em risco e que os estudos da Geomorfologia Urbana não pretendem substituir o trabalho dos engenheiros e planejadores. A Geografia Física, por meio da Geomorfologia Urbana, pode contribuir com o planejamento baseado no conhecimento geomorfológico em combinação com informações ambientais proporcionadas pelas demais áreas do conhecimento relacionadas às questões urbanas, econômicas, sociais e ambientais.

\section{Urbanização e transformação do relevo}

As atividades econômicas e sociais realizadas pelo ser humano na superfície terrestre estão situadas sobre alguma forma de relevo e algum tipo de solo já classificados ou que ainda deve ser melhor classificados. De acordo com cada intervenção antrópica, tais formas de relevo e tipo de solo poderão responder de forma menos hostil ou resultar em consequências catastróficas, de acordo com o tipo de uso 
do solo e do meio físico (Gerrard, 1992; Goudie, 1995; Goudie e Viles, 1997; Guerra, 1999 e 2001; Cunha e Guerra, 2000; Fernandes e Amaral, 2000 apud Araujo et al, 2005).

Neste sentido, a urbanização e a industrialização tiveram e ainda tem participação central nos danos ambientais ocorridos nas cidades. O crescimento desordenado tem causado pressão sobre o meio físico urbano, gerando diversas consequências como a poluição atmosférica, do solo e das águas, deslizamentos e enchentes. De acordo com Goudie e Viles (1997 apud Guerra e Marçal, 2006), as transformações culturais e tecnológicas vêm ocorrendo desde o final do século XVII através do surgimento e desenvolvimento das indústrias. Para os autores, a Revolução Industrial e a Revolução Agrícola em suas diversas etapas levou a redução do espaço necessário para o sustento da população, criando formas mais intensivas de exploração de recursos naturais para manter o crescente número de indústria bem como a também crescente população das cidades, trazendo diversas consequências negativas sobre o meio físico urbano.

Ainda segundo Goudie e Viles (op cit) os avanços da medicina moderna reduziram a mortalidade e aumentaram a longevidade da população que, por sua vez, apresentava altas taxas de natalidade, levando ao rápido crescimento da população mesmo em sociedades ainda não industrializadas. A urbanização ocorreu, portanto, de forma acelerada e é reconhecido que as grandes cidades possuem problemas ambientais peculiares, gerando uma variedade de consequências ambientais. De acordo com Guerra e Marçal (2006), o crescimento rápido e desordenado das cidades, principal mente nos países em desenvolvimento, tornou-se o maior responsável pelas transformações ambientais, modificando por vezes completamente o meio físico original anterior à ocupação humana.

Guerra op cit. mostra que, segundo Fullen e Catt (2004), no caso europeu que teve a urbanização acelerada já no século XIX, grandes áreas de solo fértil foram esterilizadas e ainda atualmente, há uma taxa de conversão de 120 ha de solos para o uso urbano por dia na Alemanha, 35ha na Áustria e Holanda e 10ha na Suíça. Em relação aos países em desenvolvimento, os autores citam o Brasil, no qual a rápida e desordenada ocupação urbana principalmente em áreas de encostas, tem gerado movimentos de massa catastróficos, provocando destruição de construções e a morte de centenas de pessoas. 
Dessa forma, o estudo das formas de relevo e do geossistema pode auxiliar não apenas na recuperação de áreas degradadas, mas também na elaboração de projetos de planejamento para que evitem a ocorrência de catástrofes ambientais que acontecem, preferencialmente, nas áreas de encostas. Segundo Araujo (2015), as encostas são "formas que dominam grande parte da superfície terrestre" e "se caracterizam por possuir declividades a partir de $2^{\circ}$ a $3^{\circ}$ apenas, sendo limitadas, nas suas partes mais elevadas, por um interflúvio, e nas partes mais baixas, por um talvegue." (Araujo et al, 2015).

As áreas mais planas, entre $0^{\circ}$ e $2^{\circ}$ de declividade, podem ser definidas como áreas deprimidas que formam planícies ou áreas elevadas que podem se localizar no topo das chapadas. Segundo Araújo op cit, "nas planícies, os processos geomorfológicos associados dominantes referem-se à deposição de materiais e infiltração e acúmulo de água nos solos", com processos erosivos ocorrendo em taxas menores. Já nas áreas de topo das chapadas, as superfícies são quase planas, predominando a infiltração de água que pode abastecer os mananciais em suas vertentes, sendo os processos erosivos bastante reduzidos nessas áreas, aumentando em direção à borda das chapadas. Essa situação muda quando a declividade no topo da chapada é superior a $3^{\circ}$, podendo ocorrer processos erosivos mais intensos que permitem a formação de voçorocas.

Nesta mesma direção, Rodrigues e Gouveia (2013) salientam que formas construídas como os aterros também são um modelo com grande potencial de instabilidade de vertentes no meio tropical úmido, visto que a geometria das formas naturais, sendo convexas, retilíneas e côncavas, são resultados dos processos de erosão e deposição que ocorrem ao longo do tempo e também podem ser aplicados às formas e sistemas criados pelo ser humano (Coelho Netto, 1994, apud Rodrigues e Gouveia, 2013).

As vertentes, sendo a ligação dinâmica entre o topo dos morros e o fundo dos vales, passam a ter os processos naturais agindo tanto sobre os sistemas naturais como também sobre os sistemas antrópicos, devendo levar-se em conta os limiares de ambos e suas interações para a realização de diagnósticos de problemas ambientais urbanos. 


\section{Histórico do Planejamento Urbano Brasileiro}

\section{A urbanização brasileira}

Embora alguns esboços de planejamento de ocupação territorial tenham ocorrido desde o início da colonização europeia sobre as terras da América Portuguesa, em seu período inicial de ocupação do território brasileiro, não havia uma estrutura com diretrizes definidas de acordo com leis ou planos com vistas a regulamentar o desenvolvimento de uma infraestrutura urbana ou de uso e ocupação ordenados do território, pois segundo Smith (1956) apud Schurmann (1999, pg. 150),

[...] ao contrário dos espanhóis, que eram instruídos por lei a executar um gradeado regular de ruas, que se entrecruzam em torno de uma praça central, os portugueses não mantinham regras, exceto a antiga de defesa através da altura. (Smith, 1956 pg. 322-323 apud Schurmann, 1999 pg. 150)

Segundo Schurmann (1999, pg 167),

[...] o século XVI foi marcado por uma urbanização lenta e incipiente, cujos resultados foram duas cidades e quatorze vilas dispersas e distribuídas por seu extenso litoral e sob constantes ameaças dos franceses.

Para Filho (2003), as cidades coloniais costumavam se desenvolver em áreas muito acidentadas e de difícil acesso, reproduzindo uma organização medieval voltada para a defesa do território e, acima de tudo, baseada na ideia de estadia provisória do colono, ou seja, sem a preocupação de uma fixação duradoura no território.

Quando refletimos sobre o planejamento urbano, no que diz respeito ao território brasileiro em sua história mais recente, podemos dar destaque aos projetos iniciados a partir do período republicano (projetos de higienização das cidades, por exemplo) e, principalmente, dos governos de Getúlio Vargas (1930-1945) com a criação do Instituto Brasileiro de Geografia e Estatística - IBGE - (Decreto-Lei n. 218 de 26 de janeiro de 1938) e Juscelino Kubistchek (1956-1960) com seus projetos que passaram a ter maior abrangência sobre o território nacional, como a construção de Brasília, a criação das Superintendências de Desenvolvimento Regionais (SUDAM, SUDENE, SUDECO, etc.), a construção de inúmeras rodovias interligando as diversas regiões, criando uma rede de comunicações e dinamizando os fluxos que circulam pelo país.

De acordo com Deák e Schiffer (1999): 
[..] foi a partir do segundo quartel deste século que a escala alcançada pela urbanização começou a provocar iniciativas por parte do Estado e modificações na administração pública. Um dos resultados nesse sentido é o aparecimento de uma nova atividade governamental com a finalidade específica de tratar dessas novas entidades que estavam surgindo: as aglomerações urbanas. É o nascimento do planejamento e, particularmente, do planejamento urbano, cujos primórdios podem ser situados no Estado Novo - no advento do qual Otávio lanni via, significativamente, a consolidação de 'uma vitória importante [...] da cidade sobre o campo'.

Para Adeodato (2010), o efetivo planejamento urbano brasileiro, realizado de forma mais sistemática com a elaboração de leis e decretos de validade nacional, pode ser dividido em dois momentos de maior destaque: os projetos abarcados pelo Plano Nacional de Desenvolvimento Urbano - PNDU - do período do regime militar (1964-1985) e a partir da promulgação da Constituição Federal de 1988 e seus desdobramentos ao longo das décadas de 1990 e 2000.

Segundo Costa (1994 pg. 1), "pode-se dizer que nenhuma política urbana foi explicitamente elaborada e adotada pelo governo central no Brasil antes da instalação do regime militar em 1964". Durante a vigência dos governos militares, a principal característica da política urbana era a centralização das decisões no governo federal, seja através de propostas ou planos de intervenção. Isto se tornava mais nítido ao se observar a criação das regiões metropolitanas, dos programas para as cidades médias e, principalmente, das políticas implementadas exclusivamente pelo Banco Nacional de Habitação - BNH - e do financiamento dos Planos de Desenvolvimento Locais Integrados (PDLIs), desenvolvidos pelo Serviço Federal de Habitação e Urbanismo - SERFHAU. (COSTA, 1994)

Contudo, de acordo com dados do IBGE (IBGE, 2015), o período em que ocorreu o regime militar foi de grandes mudanças no perfil demográfico brasileiro. Segundo a apuração realizada na década de 1950, a população brasileira tinha $36 \%$ do seu total vivendo em áreas urbanas, número que saltou para 56\% em 1970, demonstrando um franco processo de urbanização. 
Quadro 1. População Residente por situação do domicílio - 1940 - 2010

\begin{tabular}{|l|c|c|r|r|r|}
\hline \multicolumn{3}{|c|}{ Total da População Brasileira - Urbano - Rural } & Porcentagem \\
Anos & $\begin{array}{c}\text { Total } \\
\text { Urbano }\end{array}$ & Total Rural & Total & $\begin{array}{l}\text { Porcentagem } \\
\text { Rural }\end{array}$ \\
\hline 1940 & 12.880 .182 & 28.356 .133 & 41.236 .315 & 31,2 & 68,8 \\
\hline 1950 & 18.782 .891 & 33.161 .506 & 51.944 .397 & 36,2 & 63,8 \\
\hline 1960 & 31.303 .034 & 38.767 .423 & 70.070 .457 & 44,7 & 55,3 \\
\hline 1970 & 52.084 .984 & 41.054 .053 & 93.139 .037 & 55,9 & 44,1 \\
\hline 1980 & 80.436 .409 & 38.566 .297 & 119.002 .706 & 67,6 & 32,4 \\
\hline 1991 & 110.990 .990 & 35.834 .485 & 146.825 .475 & 75,6 & 24,4 \\
\hline 1996 & 123.076 .831 & 33.993 .332 & 157.070 .163 & 78,4 & 21,6 \\
\hline $\mathbf{2 0 0 0}$ & 137.755 .550 & 31.835 .143 & 169.590 .693 & 81,2 & 18,8 \\
\hline $\mathbf{2 0 1 0}$ & 160.925 .792 & 29.830 .007 & 190.755 .799 & 84,4 & 15,6 \\
\hline
\end{tabular}

\section{Evolução da População Urbana x População Rural no Brasil}

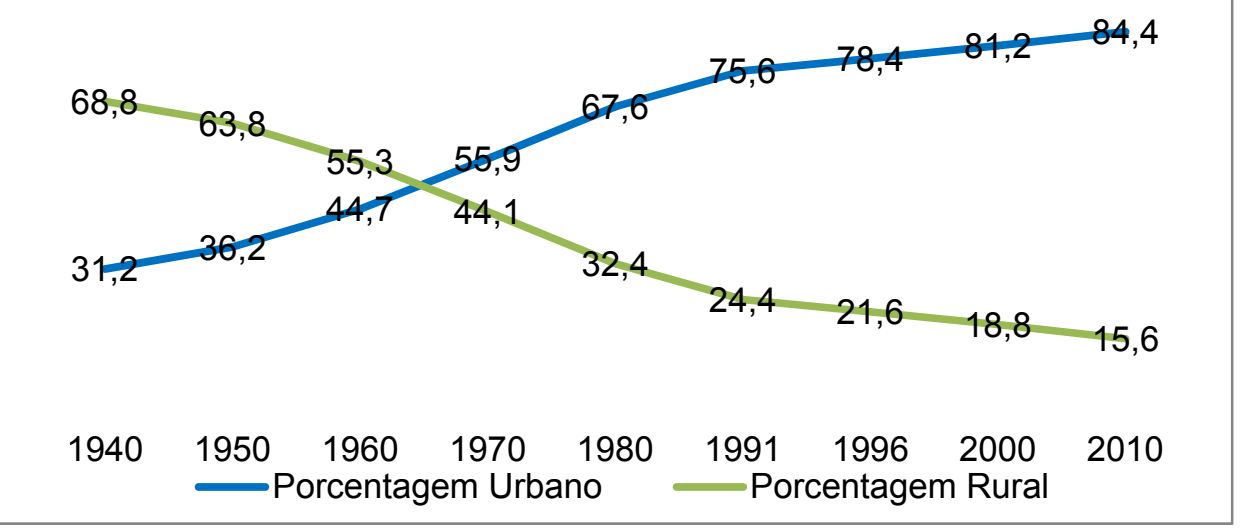

Fonte: Censo Demográfico 2010, IBGE, elaborado por Paulo Almeida.

De acordo com o quadro 1 , além do aumento proporcional verificado, ao analisar o crescimento vegetativo da população, pode-se deduzir que junto da alteração na distribuição houve também um aumento quantitativo significativo no período, passando numericamente de 18,7 milhões de pessoas vivendo nas cidades em 1950, para 52 milhões de pessoas em 1970.

Para Oliveira (1982), esse fenômeno da alta taxa de crescimento da população urbana frente à população rural se deve a formação de um vasto exército de mão de obra para atender as demandas da economia urbano-industrial, visto que a pretérita divisão social do trabalho no período colonial gerava uma sociedade dualista, com senhores de um lado, possuidores dos meios de produção (fazendas, áreas de extração mineral, grandes comércios, bancos, etc) e os escravos do outro lado da sociedade, compondo uma vasta mão de obra não assalariada, o que não permitia o 
desenvolvimento de um mercado interno de consumo, não atendendo as demandas da industrialização.

Já para Schwartz (2006) apud Adeodato (2010), é uma característica do capitalismo a unificação da força de trabalho, tornando o campo uma extensão das áreas urbanas, fazendo com que ambas sofram pelas mesmas questões.

Na visão de Kohlsdorf (1996), a urbanização até a década de 1950 trazia questões mais básicas como energia, saneamento básico, visto que as cidades brasileiras estavam iniciando uma fase de crescimento a partir das migrações campocidade. Dessa forma, as primeiras demandas da ocupação dos espaços mais periféricos da cidade estavam ligadas às necessidades básicas como luz elétrica, água encanada, coleta de esgoto e lixo.

Contudo, a partir das décadas de 1960 e 1970, começaram a surgir problemas mais graves como infraestrutura urbana de transportes, precarização das habitações, problemas ambientais, proliferação de favelas, etc. Como base destes problemas, podemos citar de um lado as altas taxas de fecundidade e natalidade e as melhorias nas questões de saneamento, tratamento de doenças, vacinações, etc, registradas no período (IBGE, 2010) que garantiram o aumento da população absoluta no Brasil e, de outro lado, o avanço da industrialização que demandava uma quantidade cada vez maior de mão de obra que, por sua vez, concentrou-se nas periferias das grandes cidades, ocupando terrenos irregulares com moradias precárias, geralmente em grandes distâncias dos centros urbanos, demandando uma expansão da prestação de serviços públicos como escolas, hospitais, iluminação, transporte público, etc.

Segundo Adeodato (2010), à época do regime militar, os problemas decorrentes da urbanização foram se agravando e exigindo soluções que fossem dadas de maneira global, não apenas a resolução de problemas pontuais. Dessa maneira, havia a necessidade de uma atuação mais sistemática e coordenada, elaborada a partir de estudos e diagnósticos realizados por órgãos e pessoal capacitado, através de planejamento, políticas e programas que melhor conduzissem a urbanização em nível nacional. O planejamento se tornou fundamental para as estratégias do governo militar para o território nacional. 
Já no período que procede ao regime militar, principalmente a partir da Constituição Federal de 1988, houve certa "rejeição" aos projetos tecnocratas e racionalistas dos militares, levando este período a uma interrupção das políticas nacionais de planejamento. Para Bonett (2014), a Constituição Federal de 1988 foi um dos pontos de sustentação do novo modelo político e institucional da Nova República. Em sua estrutura ideológica, a Constituição traria as principais ideias que conduziriam o país a partir de então, dentre elas a ordem econômica baseada em privatizações, a reafirmação do federalismo e o novo modelo de planejamento urbano, consolidado no Estatuto das Cidades.

A partir da década de 1990, a lógica neoliberal passa a ter maior peso no chamado "planejamento estratégico", com a criação de projetos urbanos pontuais, como recuperação de áreas degradadas, com "claro comprometimento mercadológico" (ADEODATO, 2010).

Legislação e Planejamento no Regime Militar (1964-1985)

A partir do golpe civil-militar aplicado em 1964, contra o então presidente João Goulart,

[...] o estado assumiu o papel de regulador das políticas e cercou-se de todo um aparato tecnocrático e institucional para ter total controle dos processos de tomada de decisão, elaboração e implementação das políticas e diretrizes nacionais nas mais diversas áreas, mas de forma prioritária, nas políticas e planos para o desenvolvimento econômico nacional." (ADEODATO, 2010, pg. 115, 116).

Para o período entre os anos de 1972 e 1974, foi lançado o I Plano Nacional de Desenvolvimento (PND I) como obrigatoriedade em atender a um requisito da Constituição Federal de 1969, que determinava a elaboração de um planejamento geral para a atuação de cada governo. Posteriormente foram lançados o PND II (1973), PND III (1980) e PND-1985, todos eles repetiam, em linhas gerais, a mesma temática e propostas do PND I. Este primeiro plano tentava concretizar algumas ideias até então abordadas superficialmente, como à integração territorial do país, tida como parte da política de desenvolvimento.

Segundo Moraes (2008), a própria estrutura institucional do Estado estava focada na ordenação do espaço. Isto pôde ser observado nos planos regionais e de integração, como o Plano de Integração Nacional - PIN - e o Plano de Desenvolvimento da Amazônia derivados do PND I, na criação do Ministério do 
Interior e de diversos outros órgãos e agências direta ou indiretamente ligados ao planejamento territorial, tais como o Banco Nacional de Habitação (BNH) e o Instituto Nacional de Colonização e Reforma Agrária (INCRA) e na manutenção das Superintendências Regionais de Desenvolvimento.

Para Maricato et al (BRASIL, 2004):

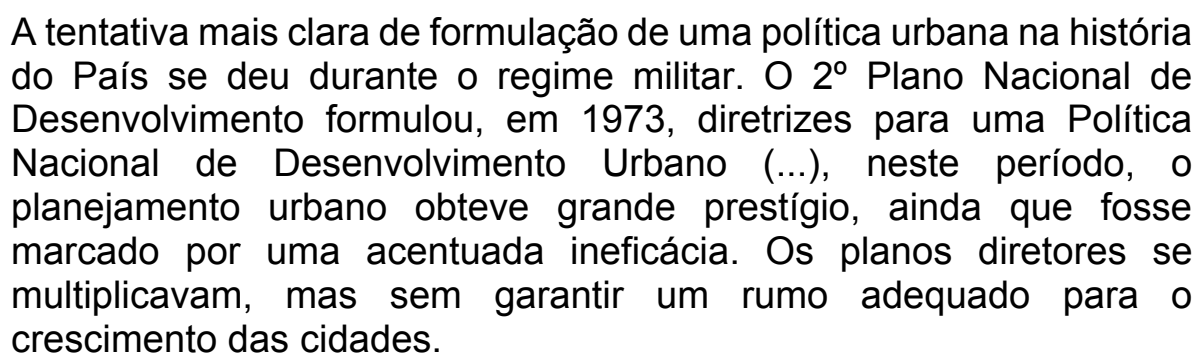

Foi a partir do governo do general Ernesto Geisel, em 1975, atrelado ao PND II que foi publicado o primeiro Plano Nacional de Desenvolvimento Urbano - PNDU. De maneira geral, o PNDU (MINISTÉRIO DO INTERIOR, 1975) reconhece como as principais dificuldades a serem enfrentadas no período: urbanização acelerada e metropolização; periferização e favelização; poluição urbana e preservação dos recursos naturais; disponibilidade precária e desigual dos equipamentos sociais urbanos; precariedade do transporte público e congestionamentos.

Como estratégia central do planejamento urbano, o documento destaca alguns pontos como:

- a definição de orientações e mecanismos para que a estrutura das cidades acompanhasse a "estratégia de desenvolvimento e a política de ocupação do espaço interior." (MINISTÉRIO DO INTERIOR, 1975 pg. 86);

- o estímulo ao planejamento, como o auxílio da Comissão Nacional de Regiões Metropolitanas e Política Urbana (CNPU), órgão criado com a função de implantar e orientar as Regiões Metropolitanas;

- definir o tipo de estrutura urbana para as diferentes regiões;

- definir as regras para o uso dos recursos federais destinados ao desenvolvimento urbano; 
Como ponto geral para todas as regiões, o plano tinha como prioridade o investimento em transporte coletivo, uso do solo, zoneamento urbano, saneamento básico, etc. Contudo, neste plano havia a definição de estratégias regionais específicas de planejamento e desenvolvimento, levando em consideração os problemas que cada região enfrentava, definindo as áreas geográficas para expansão das cidades, o disciplinamento da ocupação rural e urbana e a expansão da infraestrutura urbana.

No âmbito regional, o plano (MINISTÉRIO DO INTERIOR, 1975, p. 74) tinha como principais pontos:

i. Promover a elaboração de planos diretores para as áreas metropolitanas e projetos específicos de saneamento básico e ambiental, de transporte e de estrutura administrativa;

ii. Criar condições para implementação desses projetos e dos sistemas de administração de serviços comuns (das três esferas de poder) de peculiar interesse;

iii. Apoiar a elaboração de PDDU's (Planos Diretores de Desenvolvimento Urbano) (Norte e Nordeste) e projetos específicos de urbanismo, saneamento básico e saneamento ambiental;

iv. Estimular a consolidação dos núcleos urbanos planejados (principalmente na Amazônia);

v. Proporcionar meios para a implementação dos PDL (Plano Diretor Local) para capitais dos territórios;

vi. Patrocinar a elaboração de estudos e projetos de interesse e do desenvolvimento urbano em colaboração com governos estaduais e administrações municipais;

vii. Fomentar o treinamento de executivos das administrações municipais e estaduais (prefeitura, servidores etc.)

viii. Intensificar o aperfeiçoamento de profissionais de nível superior em cursos de pós-graduação e especialização em planejamento urbano.

No que diz respeito às políticas relacionadas ao meio ambiente, o documento dá ênfase a dois pontos específicos: poluição da atmosfera e dos recursos hídricos, ocasionados principalmente pela atividade industrial; proteção aos recursos naturais e recuperação de áreas degradadas pela poluição. Podemos notar a ausência de preocupação com desastres naturais relacionados a deslizamento de encostas ou enchentes

Segundo Adeodato (2010), os planos diretores, metropolitanos e regionais do período militar, aconteceriam sem o impacto efetivo nos problemas urbanos e seriam encarados apenas como relatórios técnicos, diagnósticos e ações propositivas, funcionando mais como instrumento de retórica do que de ação efetiva. A autora ainda 
salienta que este modelo de planejamento urbano, de ações centralizadas pelo governo federal, da concentração populacional nas metrópoles, do desequilíbrio regional e da discrepância entre o discurso e a ação da política federal foram deixados como herança para a próxima política federal, isto é, o PNDU de 2004.

\section{Legislação e Planejamento a partir da Constituição Federal de 1988.}

Devido à amplitude de assuntos acerca do planejamento urbano e todas as leis envolvidas nesta temática, será abordado apenas a legislação que trata mais especificamente do planejamento urbano em áreas de risco de desastres.

As diretrizes do planejamento urbano foram estabelecidas na Constituição Federal de 1988, no "CAPÍTULO II - DA POLÍTICA URBANA", inserido no "TÍTULO VII - Da Ordem Econômica e Financeira" (BRASIL, 1988), no Artigo 182, tendo em seu texto:

Art. 182. A política de desenvolvimento urbano, executada pelo Poder Público municipal, conforme diretrizes gerais fixadas em lei, tem por objetivo ordenar o pleno desenvolvimento das funções sociais da cidade e garantir o bem- estar de seus habitantes.

$\S 1^{\circ}$ - O plano diretor, aprovado pela Câmara Municipal, obrigatório para cidades com mais de vinte mil habitantes, é o instrumento básico da política de desenvolvimento e de expansão urbana.

O artigo 182 é bem claro sobre a responsabilidade de execução da política de desenvolvimento urbano, que deve ser realizada pelo Poder Público Municipal, contrariando as propostas dos antigos planos militares que centralizavam a coordenação das políticas urbanas nos órgãos federais como BNH e Ministério do interior, aproximando um pouco mais as políticas urbanas da população e dos problemas locais.

Para Costa (1994, pg. 3), “o ponto central dessa legislação constitucional sobre a política urbana é o princípio que determina que a terra urbana tem que cumprir uma função social". A Constituição Federal de 1988 ainda definiu os meios para se concretizar a função social da propriedade urbana, edificação e parcelamento compulsórios; a progressão na cobrança do imposto territorial ao longo do tempo; e a expropriação com finalidades sociais. O direito à usucapião foi instituído pelo art. 183 .

Segundo Rodrigues (2004), a função social da propriedade urbana existe nas Constituições Brasileiras desde 1934, mas foram explicitadas somente no Estatuto da 
Cidade, publicado em complementação aos artigos 182 e 183 da Constituição Federal, sob a Lei $n^{\circ}$ 10.257, DE 10 DE JULHO DE 2001. O artigo $2^{\circ}$ define as diretrizes para o cumprimento da função social da propriedade urbana:

I - garantia do direito a cidades sustentáveis, entendido como o direito à terra urbana, à moradia, ao saneamento ambiental, à infra-estrutura urbana, ao transporte e aos serviços públicos, ao trabalho e ao lazer, para as presentes e futuras gerações;

II - gestão democrática por meio da participação da população e de associações representativas dos vários segmentos da comunidade na formulação, execução e acompanhamento de planos, programas e projetos de desenvolvimento urbano;

III - cooperação entre os governos, a iniciativa privada e os demais setores da sociedade no processo de urbanização, em atendimento ao interesse social;

IV - planejamento do desenvolvimento das cidades, da distribuição espacial da população e das atividades econômicas do Município e do território sob sua área de influência, de modo a evitar e corrigir as distorções do crescimento urbano e seus efeitos negativos sobre o meio ambiente;

$\mathrm{V}$ - oferta de equipamentos urbanos e comunitários, transporte e serviços públicos adequados aos interesses e necessidades da população e às características locais;

Em uma breve análise, podemos entender que a função social da propriedade urbana é cumprida quando se garante o acesso a moradias em locais com saneamento básico, trabalho, lazer e serviços públicos, através da participação popular nas políticas urbanas e da cooperação entre todos, incluindo as esferas públicas, iniciativa privada e sociedade civil. O crescimento e as distorções trazidas ao longo da evolução dos municípios devem ser evitados e corrigidos através de ações de planejamento.

\section{Plano Diretor e Política Nacional de Proteção e Defesa Civil \\ O Plano Diretor é de elaboração obrigatória para os municípios que se} enquadrem em um dos critérios a saber: população urbana superior a 20 mil habitantes; que façam parte de regiões metropolitanas ou aglomerados urbanos; que estejam em áreas de especial interesse turístico; que sofram impacto ambiental 
relacionado à implantação de empreendimentos públicos ou privado, independentemente do tamanho de sua população (RODRIGUES, 2004).

Para Chamie (2010), o estatuto serviu para normatizar instrumentos que já eram utilizados pelos agentes que constroem a cidade, impondo limites e dando ênfase ao planejamento dos centros urbanos, às demandas ambientais, através de planos de proteção, preservação e recuperação de ambientes naturais e construídos através da ordenação do uso do solo. A autora ainda destaca o papel legislador que os planos diretores passaram a ter sobre a atuação do poder municipal, visto que os agentes públicos de qualquer esfera estatal devem obedecer às diretrizes estipulada pela lei, uma vez que o plano diretor funciona como uma "carta de princípios" para os governantes.

Acerca do Plano Diretor, os artigos 42 e 42-A dispõem sobre as obrigatoriedades do documento, contendo parágrafos e incisos específicos para 0 planejamento da ocupação urbana em áreas com suscetibilidade a desastres naturais. Dentre os principais pontos deste artigo, está a delimitação das áreas urbanas próprias para a construção, desde que apresentem os requisitos mínimos contidos na lei, bem como um sistema de acompanhamento e controle.

Art. 42-A. Além do conteúdo previsto no art. 42, o Plano Diretor dos municípios incluídos no cadastro nacional de municípios com áreas suscetíveis à ocorrência de deslizamentos de grande impacto, inundações bruscas ou processos geológicos ou hidrológicos correlatos deverá conter:

I - parâmetros de parcelamento, uso e ocupação do solo, de modo a promover a diversidade de usos e a contribuir para a geração de emprego e renda;

II - mapeamento contendo as áreas suscetíveis à ocorrência de deslizamentos de grande impacto, inundações bruscas ou processos geológicos ou hidrológicos correlatos;

III - planejamento de ações de intervenção preventiva e realocação de população de áreas de risco de desastre;

IV - medidas de drenagem urbana necessárias à prevenção e à mitigação de impactos de desastres; e

$\mathrm{V}$ - diretrizes para a regularização fundiária de assentamentos urbanos irregulares, se houver, observadas a Lei $n^{\circ} 11.977$, de 7 de julho de 2009 , e demais normas federais e estaduais pertinentes, e previsão de áreas para habitação de interesse social por meio da demarcação 
de zonas especiais de interesse social e de outros instrumentos de política urbana, onde o uso habitacional for permitido.

VI - identificação e diretrizes para a preservação e ocupação das áreas verdes municipais, quando for o caso, com vistas à redução da impermeabilização das cidades.

Resumidamente, podemos dizer que o artigo 42-A determina que os planos diretores de áreas suscetíveis à ocorrência de deslizamentos devem conter regras para o zoneamento que determinem a forma pela qual se dará o uso e ocupação do solo, com vistas a promover a diversificação de atividades que permitam a geração de emprego e renda locais. Para tanto, o inciso III determina a necessidade de mapeamento de áreas de suscetibilidade de deslizamentos e inundações, projetos de prevenção e transferência da população afetada por desastres para outras áreas, além das obras de drenagem destinadas a mitigação dos impactos de desastres.

$\mathrm{O}$ inciso $\mathrm{V}$ ainda determina que sejam regularizadas as áreas não legalizadas que permitam o uso e ocupação em segurança ou que se demarquem áreas para a ocupação onde o uso habitacional for permitido. Além disso, o plano diretor deve estar de acordo com os planos de recursos hídricos estabelecidos pela lei $n^{\circ}$ 9.443/1997.

Embora esteja contido no Estatuto da Cidade, o artigo 42-A, que trata diretamente das questões pertinentes ao planejamento de áreas suscetíveis a desastres ambientais, foi anexado ao estatuto após a aprovação da LEI No 12.608 , DE 10 DE ABRIL DE 2012, que institui a Política Nacional de Proteção e Defesa Civil, autoriza a criação de sistema de informações e monitoramento de desastres e que contém os regulamentos do DECRETO No 7.257, DE 4 DE AGOSTO DE 2010, que implanta o Sistema Nacional de Defesa Civil - SINDEC - e dispõem sobre suas principais diretrizes.

Este conjunto de leis e decretos causou uma profunda transformação nas regras de uso e ocupação do solo, principalmente nos grandes centros urbanos com mais de 20 mil habitantes (devido à necessidade de aprovação do Plano Diretor), seja pela obrigatoriedade dos planos de zoneamento urbano e pela consequente reordenação da exploração do solo urbano, seja também pela nova demanda criada pela necessidade de estudos de impacto ambiental, relatórios de avaliação de risco e toda uma gama de recursos técnicos, mas principalmente pela demanda em se realizar estudos profundos sobre o território ocupado ou a ocupar-se através da 
geomorfologia, geologia, geografia, climatologia, etc., estabelecendo regras e limites para a apropriação do espaço, funcionando assim como a principal ferramenta do planejamento urbano.

Ainda que diversos municípios já tivessem seus Planos Diretores e todo o aparato estatal voltado ao planejamento urbano, a novidade está no fato dos municípios passarem a ter o comando no planejamento de seu território e, mesmo que dentro de regras estipuladas pelo governo federal, tanto o poder municipal quanto a própria população passaram a ser agentes transformadores e reguladores do seu espaço de vivência.

\section{A Política Nacional de Proteção e Defesa Civil}

A Política Nacional de Proteção e Defesa Civil - PNPDEC - (BRASIL, 2012) foi criada como forma de normatizar as regras para avaliação e gestão do uso e ocupação do solo em áreas de risco, assim como para estabelecer as competências de cada esfera do estado sobre a gestão do planejamento urbano nessas áreas.

Segundo a LEI No 12.608 de 2012, a união, os estados e os municípios devem adotar medidas necessárias à redução do risco de desastres, envolvendo a participação de agentes públicos, da iniciativa privada e da sociedade.

As diretrizes desta política utilizam a abordagem sistêmica acerca das questões que envolvem o risco de desastre ambiental. As ações devem ser preventivas, com o objetivo de minimizar os desastres e tem como área de análise a bacia hidrográfica. O planejamento deve ser feito com base em pesquisas e estudos que busquem identificar e avaliar as ameaças, suscetibilidades e vulnerabilidades a desastres para evitar ou reduzir sua ocorrência.

Dessa maneira, criam-se regras para estruturar a ordenação da ocupação do solo urbano e rural, com o objetivo de conservar e proteger a vegetação nativa, recursos hídricos e a vida humana, evitando a ocupação de áreas vulneráveis a movimentos gravitacionais de massa e inundações.

Dentro da estrutura da PNPDEC, compete à união promover estudos e fomentar pesquisas sobre as causas e possibilidades da ocorrência de desastres, incentivando a instalação de centros universitários de ensino e de pesquisas sobre desastres, sejam presencialmente ou através de módulos e cursos à distância. Cabe 
ainda ao governo federal instituir e manter um sistema de informações e monitoramento de desastres, identificando áreas de risco nas regiões geográficas e bacias hidrográficas do país.

Os estados devem dar apoio à união e aos municípios no auxílio ao combate e a prevenção, bem como implantar uma rede de monitoramento meteorológico, hidrológico e geológico das bacias com risco de desastre.

Já os municípios que se enquadrarem nos critérios de obrigatoriedade do Plano Diretor, devem identificar e mapear as áreas de risco de desastre e vedar novas ocupações nessas áreas, tomando providências para reduzir os riscos, fazendo obras de segurança e, caso necessário, removendo edificações e realocando os ocupantes. Os municípios que estiverem inscritos no Cadastro Nacional de Municípios com áreas suscetíveis de deslizamentos de grande impacto, inundações bruscas ou processos geológicos, hidrológicos ou correlatos, também devem elaborar o mapeamento contendo as áreas mais vulneráveis a desastres e elaborar carta geotécnica de aptidão às áreas pretensas de urbanização.

\section{Lei da Mata Atlântica}

Em dezembro de 2006 foi decretada a Lei Federal 11.428, que "dispõe sobre a utilização e proteção da vegetação nativa do Bioma Mata Atlântica..." e tem como principal objetivo o “(...) desenvolvimento sustentável, ...a salvaguarda da biodiversidade, da saúde humana, dos valores paisagísticos, estéticos e turísticos, do regime hídrico e da estabilidade social " (BRASIL, 2006).

A lei define os critérios de preservação e conservação estabelecidos especificamente para este bioma, suas definições e as condições permitidas para o uso e ocupação de áreas recobertas este tipo de formação.

Dentre os principais pontos desta lei, pode-se destacar as normas de uso e ocupação do solo em áreas recobertas pelo bioma da mata atlântica ou localizadas nas bordas de unidades de conservação:

- Ficam proibidos corte e supressão de vegetação primária ou em estágio de regeneração médio e avançado do Bioma Mata Atlantica que abriguem espécies da flora e fauna em extinção; que exerçam função de proteção aos mananciais; que protejam o entorno de unidades de conservação; 
- O corte e supressão somente serão autorizados mediante estudos de viabilidade técnica e esgotadas todas as alternativas e apenas em casos utilidade pública e interesse social;

Além disso, há destaques específicos para as regiões metropolitanas que abrigam o Bioma Mata Atlântica em seu território, com destaque para:

- A proibição da supressão de vegetação primária do Bioma Mata Atlântica para fins de loteamento ou edificação;

- A supressão da vegetação secundária em perímetro urbano aprovado em data anterior a vigência desta lei poderá ser realizada apenas mediante autorização prévia do órgão estadual competente e somente para loteamentos que garantam a preservação uma área mínima de $50 \%$ da área total coberta por esta vegetação e atendido o disposto no Plano Diretor Municipal, sendo totalmente proibida a supressão da vegetação em perímetros urbanos aprovados após a vigência desta lei;

\section{O Novo Código Florestal}

No ano de 2012, através da lei 12.651, o Governo Federal instituiu o novo código florestal brasileiro, o qual reafirma as Áreas de Proteção Permanente - APPs - entendidas como:

[..] área protegida, coberta ou não por vegetação nativa, com a função ambiental de preservar os recursos hídricos, a paisagem, a estabilidade geológica e a biodiversidade, facilitar o fluxo gênico de fauna e flora, proteger o solo e assegurar o bem-estar das populações humanas. (BRASIL, 2012).

Segundo o Ministério do Meio Ambiente, as APP's em meio urbano tem diversas funções, tais como a proteção ao solo, preservando sua permeabilidade de maneira a evitar inundações e enxurradas advindas da ocupação irregular, preservar a função ecológica de refúgio de determinadas áreas bem como a dos corredores ecológicos que permitem o fluxo de fauna e flora, principalmente em áreas urbanas, assim como amenizar os desequilíbrios climáticos urbanos, tais como as "ilhas de calor".

No que se refere às áreas de proteção permanente, edificar nessas áreas é proibido, exceto quando há interesse social (o que abre uma grande brecha para o 
zoneamento urbano em áreas irregulares). A lei federal 12.651 estabelece diversas situações de proteção permanente em seu artigo $4^{\circ}$, estando elas em zonas rurais ou urbanas, dentre as quais, podemos destacar:

I - as faixas marginais de qualquer curso d'água natural perene e intermitente, excluídos os efêmeros, desde a borda da calha do leito regular, em largura mínima de

a) 30 (trinta) metros, para os cursos d'água de menos de 10 (dez) metros de largura;

b) 50 (cinquenta) metros, para os cursos d'água que tenham de 10 (dez) a 50 (cinquenta) metros de largura;

c) 100 (cem) metros, para os cursos d'água que tenham de 50 (cinquenta) a 200 (duzentos) metros de largura;

d) 200 (duzentos) metros, para os cursos d'água que tenham de 200 (duzentos) a 600 (seiscentos) metros de largura;

e) 500 (quinhentos) metros, para os cursos d'água que tenham largura superior a 600 (seiscentos) metros;

II - as áreas no entorno dos lagos e lagoas naturais, em faixa com largura mínima de:

a) 100 (cem) metros, em zonas rurais, exceto para o corpo d'água com até 20 (vinte) hectares de superfície, cuja faixa marginal será de 50 (cinquenta) metros;

b) 30 (trinta) metros, em zonas urbanas;

III - as áreas no entorno dos reservatórios d'água artificiais, decorrentes de barramento ou represamento de cursos d'água naturais, na faixa definida na licença ambiental do empreendimento;

IV - as áreas no entorno das nascentes e dos olhos d'água perenes, qualquer que seja sua situação topográfica, no raio mínimo de 50 (cinquenta) metros;

$\mathrm{V}$ - as encostas ou partes destas com declividade superior a $45^{\circ}$, equivalente a $100 \%$ (cem por cento) na linha de maior declive;

IX - no topo de morros, montes, montanhas e serras, com altura mínima de 100 (cem) metros e inclinação média maior que $25^{\circ}$, as áreas delimitadas a partir da curva de nível correspondente a $2 / 3$ (dois terços) da altura mínima da elevação sempre em relação à base, sendo esta definida pelo plano horizontal determinado por planície ou espelho d'água adjacente ou, nos relevos ondulados, pela cota do ponto de sela mais próximo da elevação; 
$X$ - as áreas em altitude superior a 1.800 (mil e oitocentos) metros, qualquer que seja a vegetação;

Dessa maneira, ficam definidas as áreas de proteção permanentes e faixas não edificáveis, com destaque para o entorno dos cursos d'água naturais, com faixa mínima de 30 metros de distância, seja de rios ou de lagos e lagoas naturais em áreas urbanas e de 50 metros de distância para as nascentes e olhos d'água em qualquer altitude e situação topográfica. Contudo, o novo código florestal revoga a resolução CONAMA 369/06, visto que esta se baseava no antigo código florestal, conforme orientação dada pela Advocacia Geral da União (BRASIL, 2013), e aplica novas regras para a supressão de vegetação e ocupação de APP's, quando se tratar de interesse social.

Portanto, o novo código florestal permite a ocupação de APPs, desde que entendido o interesse social e respeitada as diversas regras, tais como a realização de estudos técnicos que demonstrem a melhoria das condições ambientais em relação as condições anteriores, obras de saneamento básico, de controle de riscos geotécnicos e inundações, recuperação de áreas degradadas não regularizáveis, comprovação de melhoria na sustentabilidade, não ocupação de áreas de risco e principalmente a melhoria da habitabilidade.

De maneira geral, no conjunto da legislação pode ser percebida uma tentativa de se estabelecer níveis de segurança e preservação da vida, visto que áreas de instabilidade geológica ou próximas a cursos d'água podem trazer riscos de deslizamento de encostas ou enchentes. A lei ainda tem com um de seus objetivos a preservação das condições ideais das formações vegetais e dos corpos d'água de maneira a garantir o bom funcionamento dos sistemas naturais.

Nota-se ainda que a legislação ambiental federal é o pressuposto para a elaboração das legislações estaduais e municipais e estas, por sua vez, devem estabelecer regras de igual ou maior restrição, que serão apresentadas mais adiante neste trabalho. 


\section{Localização e descrição da área de estudo}

A área escolhida para a realização deste estudo é a Microbacia Taquara do Reino, localizada junto ao loteamento conhecido como Recreio São Jorge, pertencente ao bairro do Cabuçu no município de Guarulhos, Região Metropolitana de São Paulo - RMSP. A área selecionada localiza-se na porção norte do município, dentro da Área de Preservação Ambiental (APA) Cabuçu - Tanque Grande.

Para diversos autores, a bacia hidrográfica vem sendo adotada como uma unidade mais complexa que envolve componentes estruturais, processos biológicos, geológicos, sociais e econômicos, constituindo uma unidade ideal de integração entre gerenciamento, pesquisa e planejamento ambiental (Tundisi \& Schiel, 2002; Tundisi, 2003; Carmo \& Silva, 2010; apud Siqueira \& Henry-Silva, 2011).

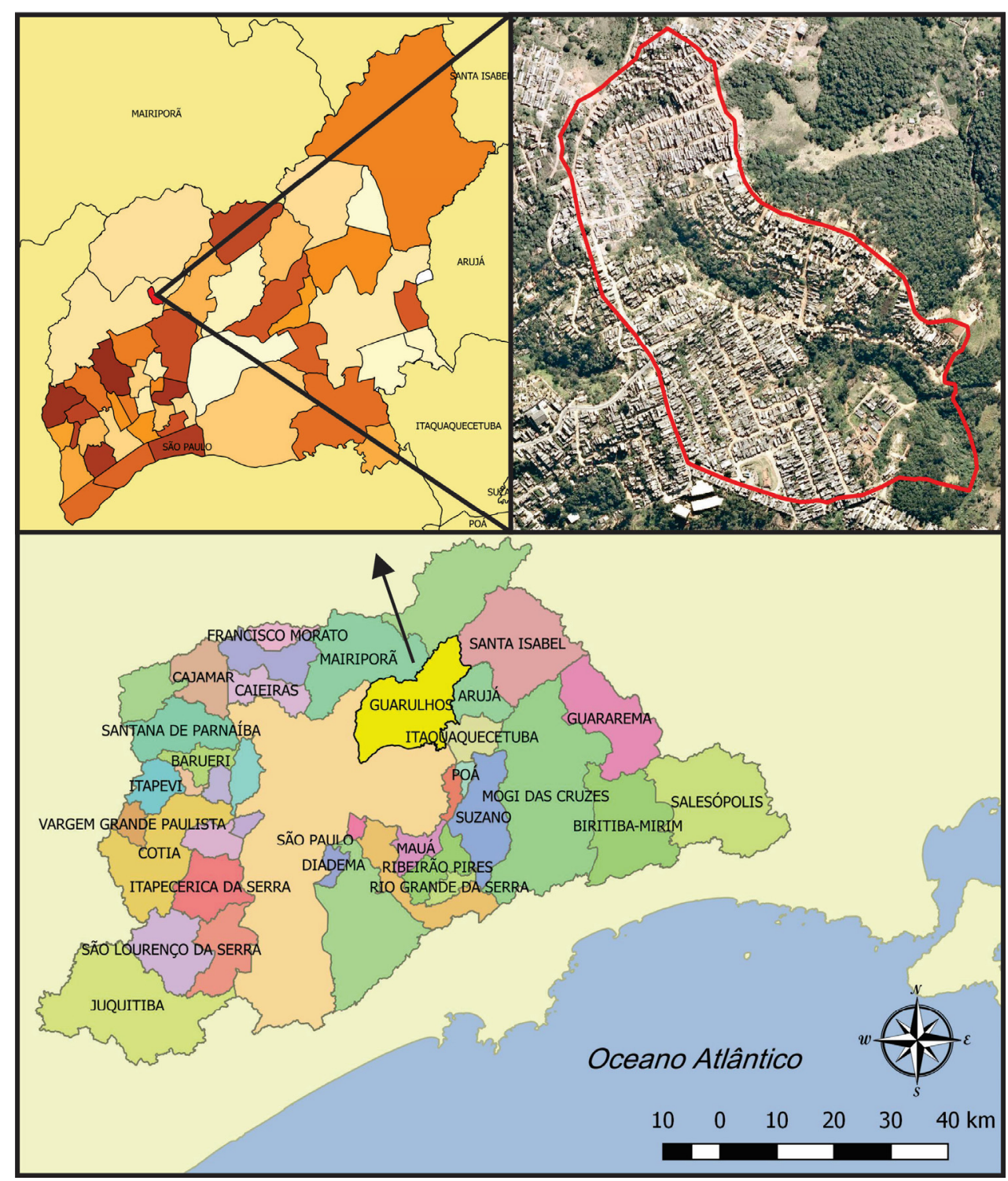

Mapa 1. Região Metropolitana de São Paulo - RMSP - Município de Guarulhos Microbacia Taquara do Reino. Fonte: Prefeitura do Município de Guarulhos e Instituto Brasileiro de Geografia e Estatística - IBGE. 


\section{Características do Município de Guarulhos}

O Município de Guarulhos é um dos integrantes da Região Metropolitana de São Paulo - RMSP - formada por 39 municípios. Guarulhos está localizado a nordeste da capital paulista, fazendo limite com o Município de São Paulo a oeste, limitado pelo Rio Cabuçu de Cima e ao sul, limitado pelo rio Tietê; com Itaquaquecetuba a sudeste; com Arujá a Leste; com Santa Isabel a nordeste e com Mairiporã e Nazaré Paulista ao norte.

Colonização e exploração aurífera - Breve histórico do Município de Guarulhos

O Município de Guarulhos teve sua história iniciada com a fundação da Aldeia de Nossa Senhora da Conceição dos Guarulhos, em 8 de dezembro de 1560, pelo padre jesuíta Manuel de Paiva. A ideia inicial era a catequização dos índios Maromomi, também chamados de Guarulhos, a partir da criação de uma missão jesuítica. Contudo, no ano de 1597 foram descobertas algumas minas de ouro na região, atraindo a atenção da coroa portuguesa, bem como de inúmeros bandeirantes e grandes proprietários.

Diversas lavras de ouro foram criadas na área do atual município de Guarulhos, com mão-de-obra escrava predominantemente indígena (Guarulhos, 2007). No ano de 1685 , a região foi elevada a categoria de freguesia, devido à prosperidade da extração aurífera, com o nome de Nossa Senhora da Conceição dos Guarulhos.

A partir do século XVIII ocorreu a introdução da mão-de-obra escrava africana, que pode ser verificada na construção, no ano de 1750, da Igreja da Irmandade de Nossa Senhora do Rosário dos Homens Pretos. Entretanto, a partir de 1850, com o fim do tráfico negreiro e a queda na extração do ouro, ocorreu um êxodo populacional da Freguesia de Nossa Senhora da Conceição de Guarulhos, gerando grande redução em sua força de trabalho e população (Guarulhos, 2007).

A partir de 1870, a freguesia passou a receber imigrantes europeus, libaneses e asiáticos e em 24 de outubro de 1880, foi elevada à condição de vila, deixando de pertencer ao município de São Paulo. No ano de 1906, a vila de Nossa Senhora da Conceição dos Guarulhos foi elevada à categoria de cidade, passando a chamar-se apenas de Guarulhos.

No ano de 1915, a cidade recebe a construção de uma linha férrea, conhecida como Estrada de Ferro Tramway da Cantareira, ligando Guarulhos à zona norte de São Paulo. Esse fato, associado ao surto industrializante do período da Primeira 
Guerra Mundial, colaborou com o surgimento de diversos pequenos empreendimentos industriais em Guarulhos. A partir da segunda metade do século XX, a cidade tornouse um grande polo industrial da Região Metropolitana de São Paulo - RMSP.

MINERAÇÃO DE OURO - INÍCIO DA EXPANSÃO URBANA DA CIDADE DE GUARULHOS

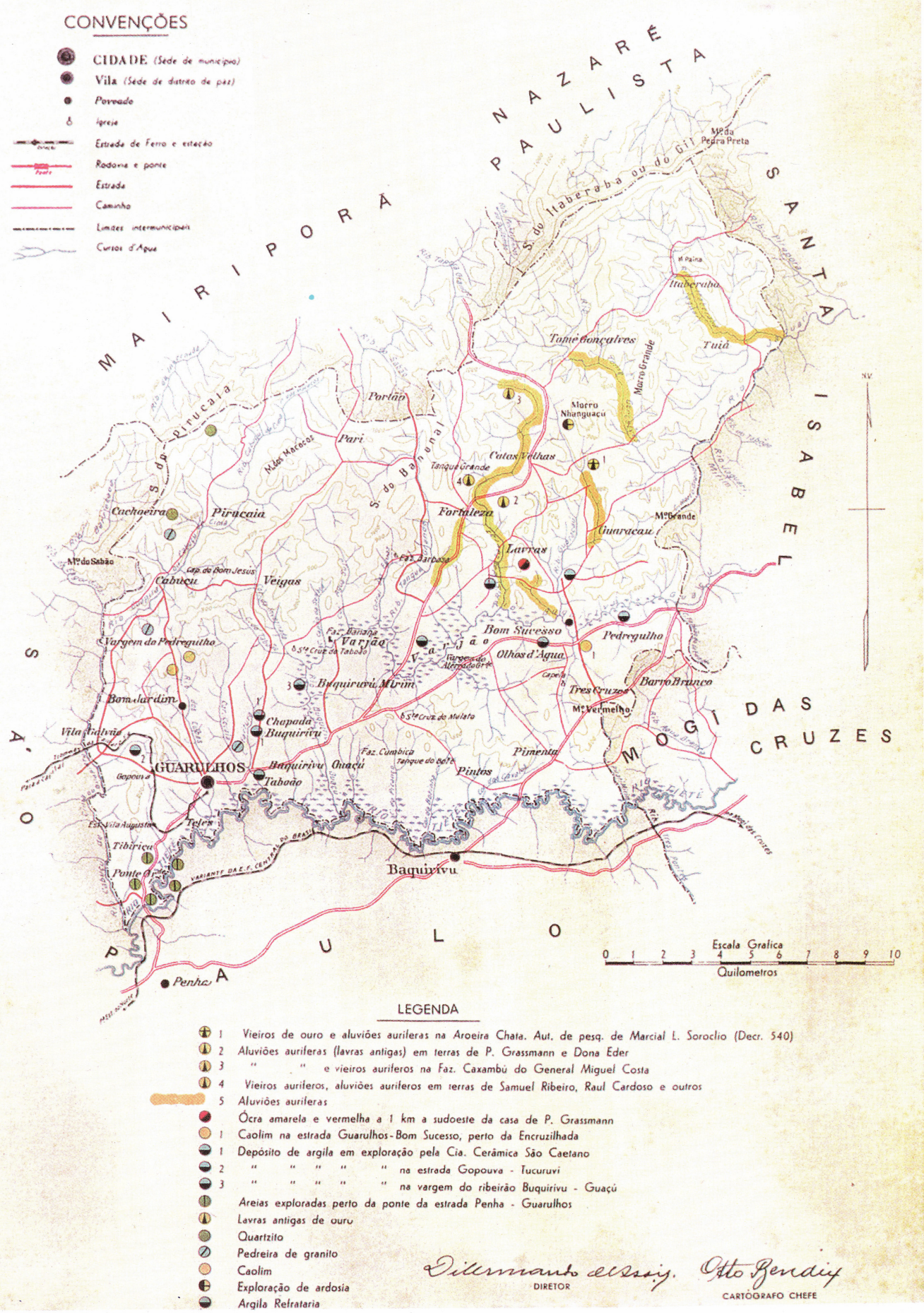

Fonte: Instituto Geográfico e Geológico - IGG/Secretaria de Agricultura do Estado de São Paulo, 1950.

Mapa 2. Mineração de ouro - Início da expansão urbana da Cidade de Guarulhos. 
O município de Guarulhos tem atualmente uma população estimada em 1.312.197 habitantes, distribuídos em $318,675 \mathrm{~km}^{2}$ de área total (IBGE, 2015). A economia do município ocupa a $8^{\mathrm{a}}$ posição no Produto Interno Bruto nacional e $2^{\mathrm{a}}$ posição no Estado de São Paulo, com um montante de $\mathrm{R} \$ 44,6$ bilhões e PIB per capita de $\mathrm{R} \$ 35.893,99$, com destaque para a produção industrial, na qual ocupa a $8^{\mathrm{a}}$ posição no ranking do PIB industrial do país, com $R \$ 9,4$ bilhões, gerando mais de 115 mil empregos (IBGE, 2012; MTE-RAIS apud PMG, 2015).

Guarulhos apresentou um processo de urbanização bastante acelerado, acompanhando em partes a evolução da RMSP, saltando de um total de 237.900 habitantes, em 1970, para 532.726 em 1980, atingindo o total de $1.072 .717 \mathrm{em} 2000$ e 1.221.979 em 2010, números estes que representam um aumento de $515 \%$ no total da população em 40 anos. Para efeito de comparação sobre o mesmo período, a capital paulista saltou de 5,9 milhões de habitantes em 1970, para 11,2 milhões em 2010, atingindo um crescimento de 188,2\%. Esse crescimento acelerado e concentrado inicialmente na região sudoeste do município se direcionou para as regiões leste e norte a partir da década de 1970, exercendo maior pressão sobre áreas florestadas e montanhosas do município, conforme verificado no Mapa 3:

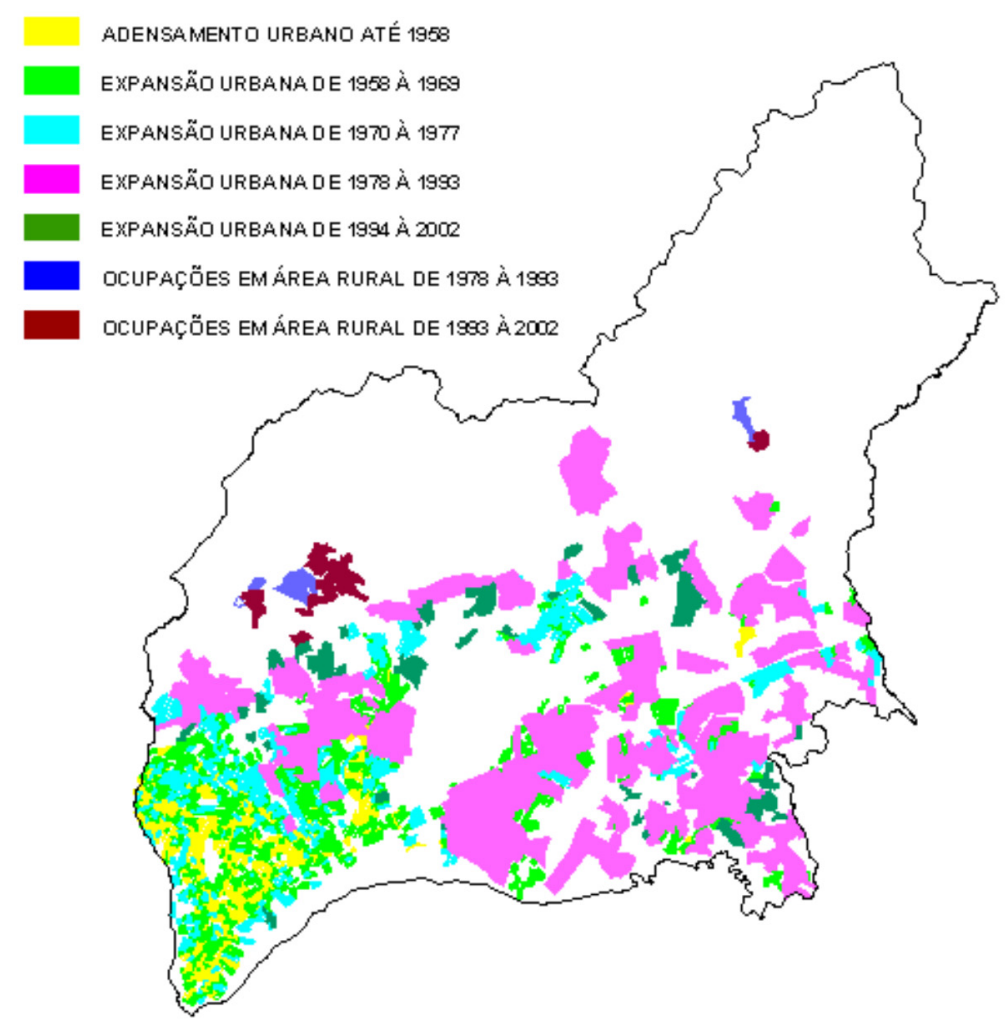

Mapa 3. Evolução urbana do município de Guarulhos (PMG, 2007). 
Embora existam áreas com características rurais tais como propriedades de produção agrícola, ruas sem pavimentação, pouca ou nenhuma iluminação pública, a prefeitura municipal de Guarulhos, através da LEI № 6.253, DE 24 DE MAIO DE 2007, em seu artigo 26, define como: “

[...] urbano todo o território municipal resguardada áreas de tipificação rural, que deverão ser cadastradas pela Prefeitura de Guarulhos, na forma como dispuser o Decreto do Executivo. (PMG, 2007).

Entretanto, o zoneamento rural não foi instituído, seja através de Decreto do Executivo ou através de projeto de lei, o que significa que a totalidade da população de Guarulhos seja urbana.

No que diz respeito às condições de moradia da população, segundo dados do IBGE (2010), do total de 360.800 domicílios ocupados e recenseados, 57.653 domicílios pertenciam a aglomerados subnormais (favelas), que por sua vez somavam 156 núcleos com uma população total de 214.885 habitantes.

Segundo o Plano Estratégico Municipal para Assentamentos Subnormais PEMAS - elaborado no ano de 2004, 24,5 mil domicílios estavam localizados em áreas de risco, abrigando uma população de mais de 95 mil habitantes. Deste total, 14,5 mil domicílios (60\%) apresentavam risco de desabamento e 5,4 mil domicílios (22\%) encontram-se com risco de enchentes (PMG, 2004).

Com o objetivo de melhor caracterizar e avaliar as condições de risco, no ano de 2004, a Prefeitura Municipal de Guarulhos realizou o Plano Municipal de Redução de Risco - PMRR - através do qual foram identificados 1,8 mil domicílios localizados em áreas de instabilidade de taludes e encostas e 341 domicílios localizados em margem de córrego, expostos ao risco de solapamento (PMG, 2007). Há que se considerar que PEMAS e PMRR foram elaborados com diferentes metodologias, o que gerou um número discrepante e impossibilitou a comparação entre ambos (PMG, 2011).

\section{Características Geográficas}

Clima

Por estar situada na latitude do trópico de Capricórnio, a Região Metropolitana de São Paulo está no limite das zonas climáticas tropical e subtropical. Em sua porção mais ao norte, a RMSP possui um clima classificado como mesotérmico brando úmido, tendo períodos secos de um a dois meses (NIMER, 1989). 
Pode-se dizer que a dinâmica atmosférica da RMSP é um tanto complexa, por sofrer influência de frentes polares (associadas às entradas da Massa Polar Atlântica) e dos sistemas tropical, tropical continentalizado e subtropical úmido, com a existência de dois domínios climáticos zonais incidentes: um oriundo do sistema equatorial e tropical ao norte e outro ao sul, oriundo do sistema polar.

Pela classificação de Köppen, esta região possui o predomínio de climas temperados quentes, com temperatura média do mês mais frio entre -3 e $18^{\circ} \mathrm{C}$. Ocorrem, na área da RMSP, os tipos Cw (clima temperado quente) com estação seca, predominando Cwa (temperado quente com chuvas de verão) em que as temperaturas médias do mês mais quente são iguais ou superiores a $22^{\circ} \mathrm{C}$ e $\mathrm{Cwb}$ (temperado com verão quente) onde as temperaturas dos meses mais quentes ficam entre 10 e $22^{\circ} \mathrm{C}$ (MOREIRA; PIRES NETO, 1998).

Segundo Monteiro (1973), o clima da região é classificado como tipo-úmido face oriental e subtropical de continente, com domínio das massas de ar tropicais (massa Tropical atlântica - mTa; e massa Tropical continental - mTc) e pela massa Polar atlântica - mPa, com influência das frentes equatoriais marítimas e de alísios de sudeste.

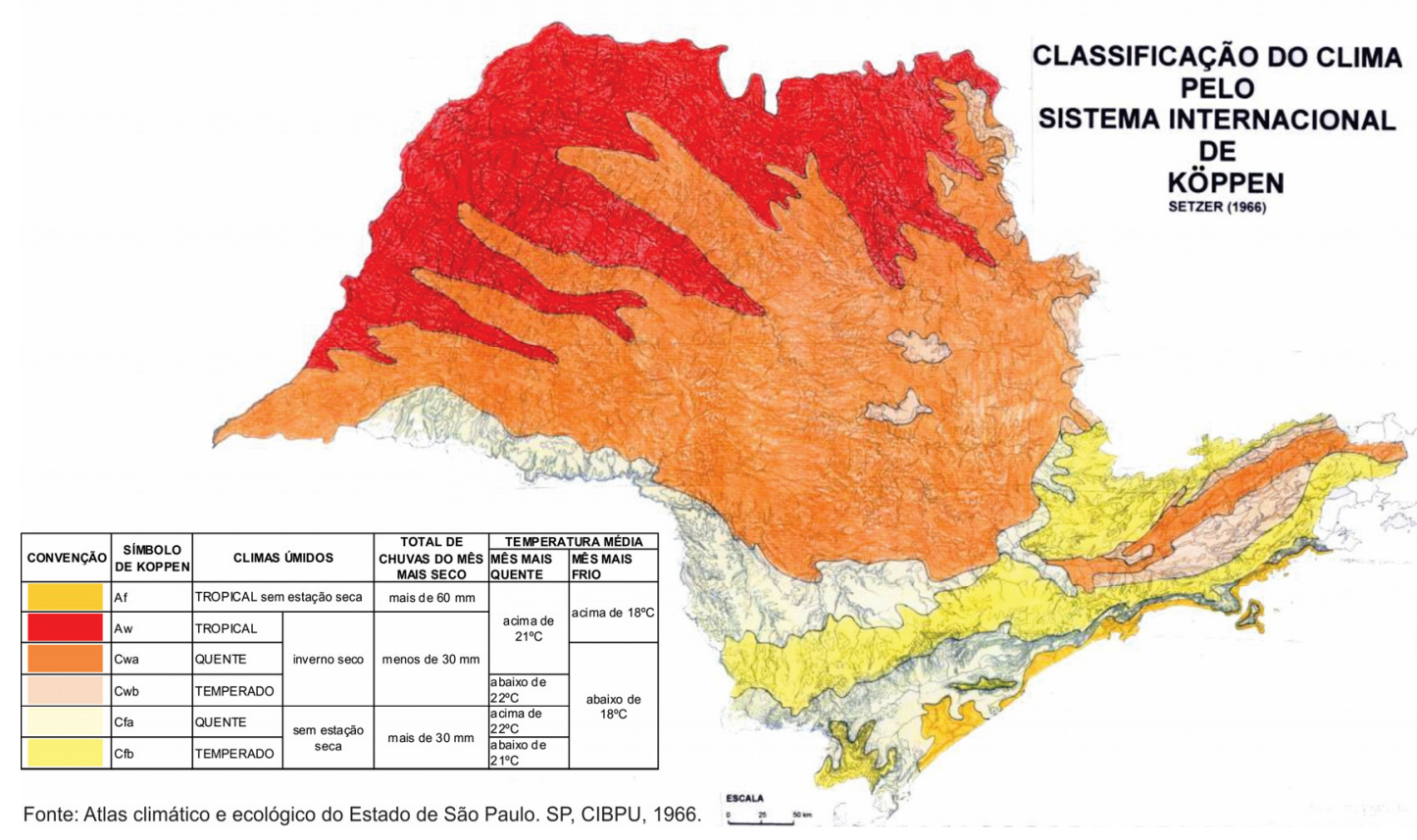

Mapa 4. Classificação do clima do Estado de São Paulo pelo sistema internacional de Koppen

A RMSP está localizada em um setor do Planalto Atlântico, com grande influência da proximidade do planalto com o litoral, isto é, da maritimidade 
principalmente ao sul, onde a região faz contato com a escarpa da Serra do mar, área de transição entre o planalto e a planície costeira. $O$ alinhamento das escarpas da Serra do Mar é paralelo ao litoral, formando uma grande barreira aos ventos úmidos do oceano e causando chuvas orográficas ao longo de suas encostas, com precipitação variada entre $2000 \mathrm{~mm} / \mathrm{ano}$, podendo chegar a $4500 \mathrm{~mm} / \mathrm{ano}$ em alguns pontos (NIMER, 1989).

Contudo, o alinhamento da escarpa que favorece as precipitações ao longo da costa litorânea acaba por funcionar como uma barreira para a entrada da umidade nas regiões planálticas, reduzindo as precipitações para valores abaixo de 1500 $\mathrm{mm} / a n$. Essa relação de redução se dá quando comparada tanto com a região litorânea, quanto com as áreas adjacentes. Entretanto, a pluviosidade verificada nos períodos de outono/inverno é maior na bacia da RMSP do que nas regiões planálticas do interior do Estado devido à proximidade com o litoral, conforme mostram os dados dos climograma abaixo:

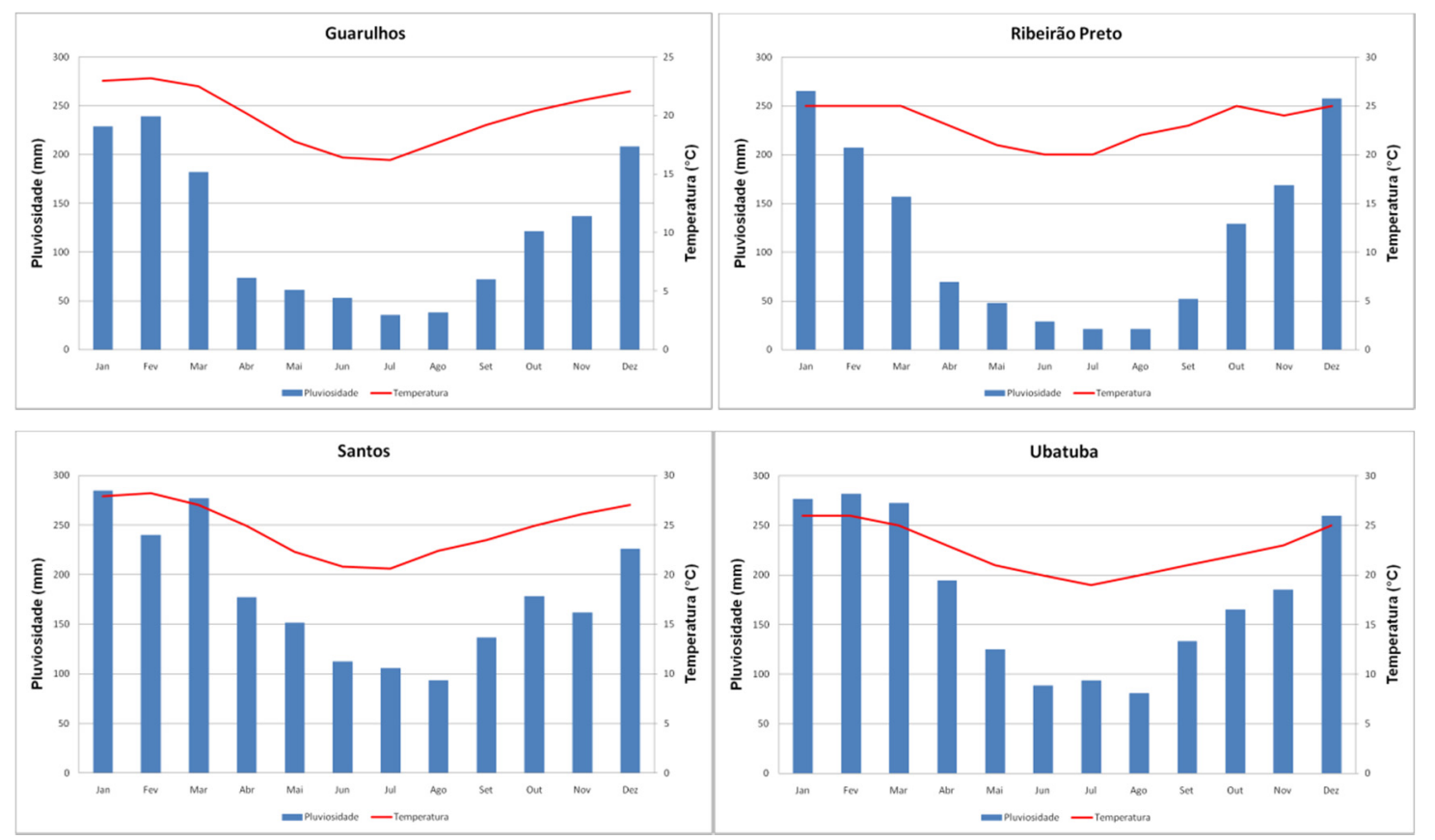

Gráfico 1. Climograma Comparativos Guarulhos, Santos, Ribeirão Preto, Ubatuba, Fonte: CEPAGRI UNICAMP 


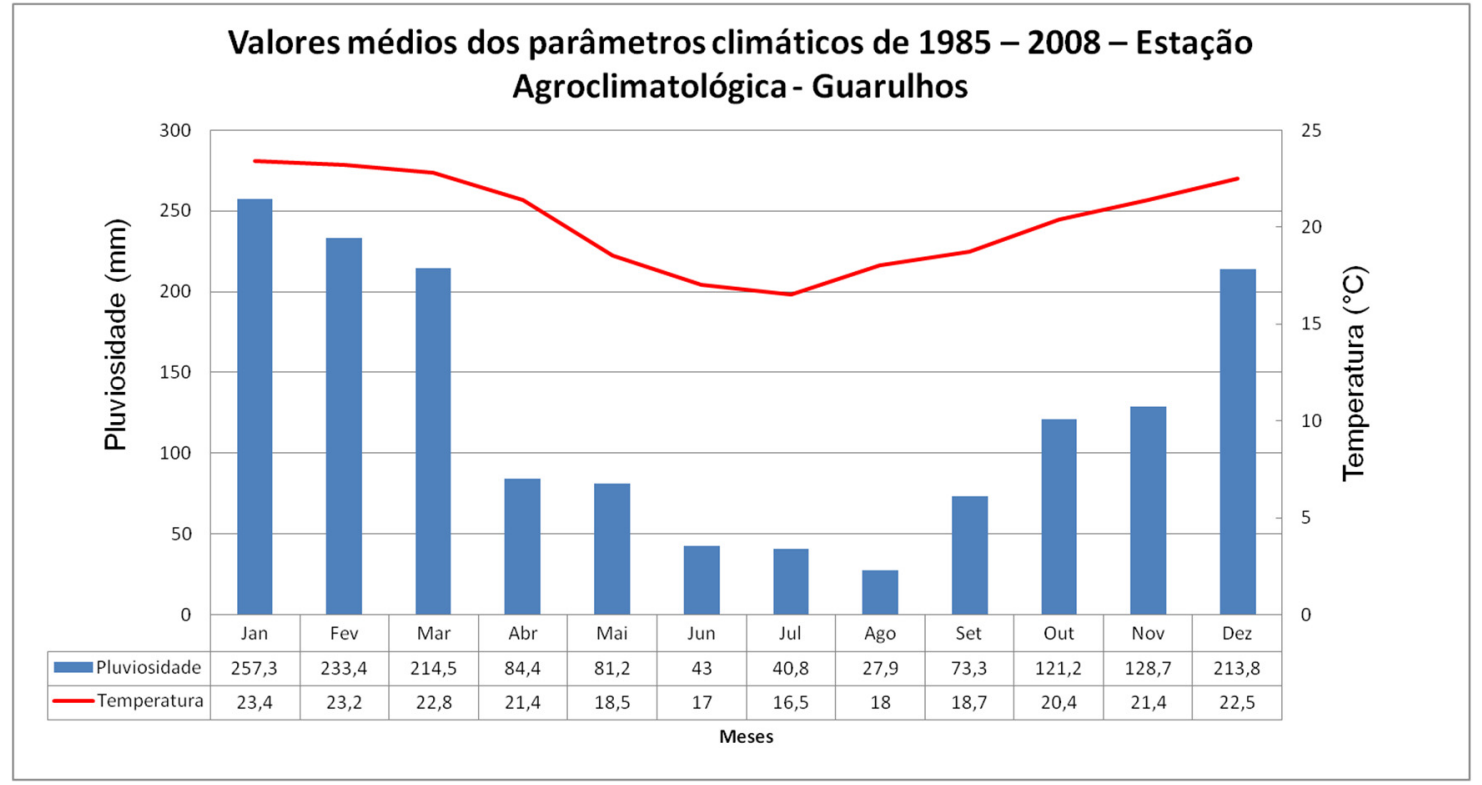

Gráfico 2. Climograma do período entre 1985 e 2008 - com base nos dados obtidos na estação agroclimatológica UnG/INMET.

PRECIPITAÇÕES MÉDIAS ANUAIS E MENSAIS

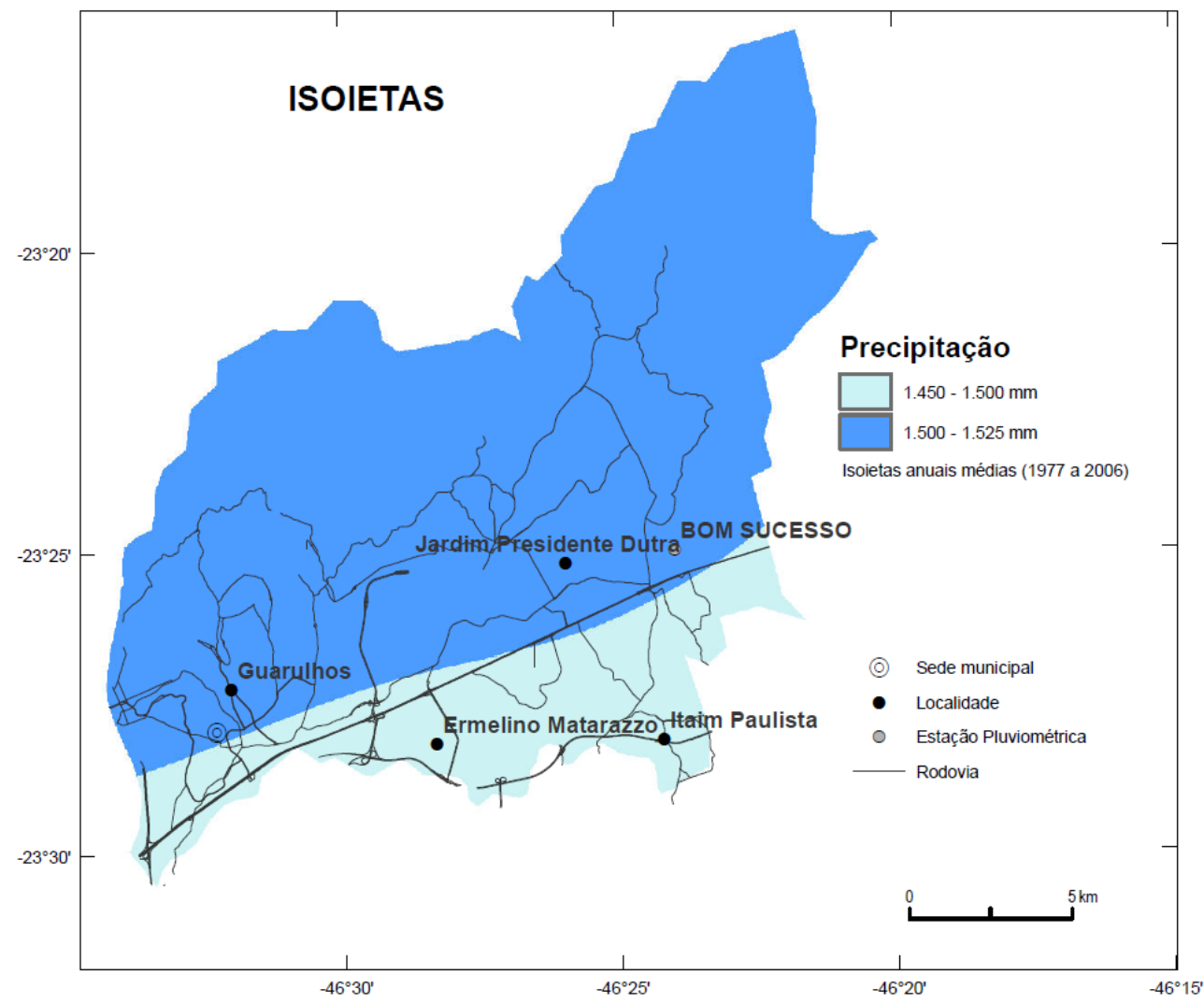

Mapa 5. Precipitações médias anuais e mensais. Fonte: IPT/CPRM, 2014.

Segundo Tarifa e Armani (2001), com relação às condições climáticas predominantes na região do bairro do Cabuçu, pode-se observar a ocorrência de dois tipos climáticos condicionados pela topografia: o Clima Tropical Úmido de Altitude do 
Planalto Paulistano, representado pelo mesoclima dos morros baixos, morrotes, colinas e das grandes planícies fluviais; e o Clima Tropical Úmido da Serra da Cantareira-Jaraguá, que apresenta condições mais amenas devido a variação da altitude entre 800 e 1200 metros.

Os valores do gráfico 2 representam as médias climáticas coletadas no período 1985-2008 em uma estação localizada na região central de Guarulhos: Quando comparados ao gráfico produzido a partir dos dados do CEPAGRI-UNICAMP, podemos notar que há diferenças entre os dados registrados, seja pela localização dos equipamentos de captura, seja pelo período de coleta dos dados, revelando a complexidade climática da região. Há que se considerar ainda os diferentes fatores fisiográficos que contribuem para as variações climáticas, como:

Trajetória do Sol (movimento aparente) e as variações diurnas e noturnas dos ventos, associadas à orientação das ruas, praças, avenidas, edificações baixas, prédios altos, criam um "desenho" ou uma superfície topológica, criam volumes, rugosidades, materiais, inclinações e exposições redefinindo os topoclimas urbanos. As trocas de radiação e do vento, externas e internas são fundamentais para se compreender o aquecimento-resfriamentos e a qualidade do ar nesses volumes cada vez mais próximos da superfície do solo e dos lugares onde $\mathrm{o}$ homem vive, trabalha e produz socialmente (microclimas urbanos) (TARIFA e ARMANI, 2001, p. 50)

O acelerado processo de urbanização verificado na região e a formação de ilhas de calor são amortecidos, em parte, pela presença de significativos remanescentes de Mata Atlântica no cinturão verde que podem abrandar os efeitos da urbanização (LOMBARDO, 1985; SEPE e TAKIYA, 2004).

\section{Cobertura Vegetal}

Do total de seus $318,6 \mathrm{~km}^{2}$ de área, $32 \%$ são cobertos por vegetação nativa, com destaque para o Núcleo Cabuçu, pertencente ao Parque Estadual da Serra da Cantareira, que ocupa 26,7 km² e a Área de Proteção Ambiental - APA - CabuçuTanque Grande que ocupa 32,2 km². A maior parte da vegetação nativa de Guarulhos pertence ao bioma da Mata Atlântica, tendo a Floresta Ombrófila Densa Mista ou Aberta, a Floresta Semidecidual e a Floresta Estacional Decidual como as principais formações vegetais.

Segundo a Fundação SOS Mata Atlântica (2015), a Mata Atlântica abrangia uma área equivalente a $1.315 .460 \mathrm{~km}^{2}$ e estendia-se originalmente ao longo dos estados do Rio Grande do Sul, Santa Catarina, Paraná, São Paulo, Rio de Janeiro, 
Minas Gerais, Espírito Santo, Goiás, Mato Grosso do Sul, Bahia, Alagoas, Sergipe, Paraíba, Pernambuco, Rio Grande do Norte, Ceará e Piauí.

Ainda segundo a Fundação SOS Mata Atlântica e IBGE (2014), atualmente vivem 145 milhões de pessoas em áreas ocupadas ou anteriormente ocupadas pelo bioma da Mata Atlântica, o que corresponde a mais de $70 \%$ da população brasileira, estabelecidas em 2.481 municípios totalmente inseridos ou em 948 municípios parcialmente inseridos na área do bioma.

Devido à proximidade da costa, dos tipos de relevo e das combinações entre clima e solo, a Mata Atlântica desenvolveu um complexo biótico bastante rico, contendo uma grande parte da biodiversidade biológica brasileira, abrigando muitas espécies endêmicas (ARAÚJO et al, 2007 apud ANDRADE, 2009).

No caso específico da Serra da Cantareira, a vegetação é classificada como Floresta Ombrófila Densa Montana (BRASIL, 1983 apud ANDRADE, 2009), formando uma transição entre a Mata Atlântica e a Mata de Planalto, com característica Semicaducifolia (BAITELLO et al, 1993), tendo no município de Guarulhos uma área representante dessa formação na APA do Cabuçu-Tanque Grande. As principais formações vegetais estão representadas no Mapa 6: 


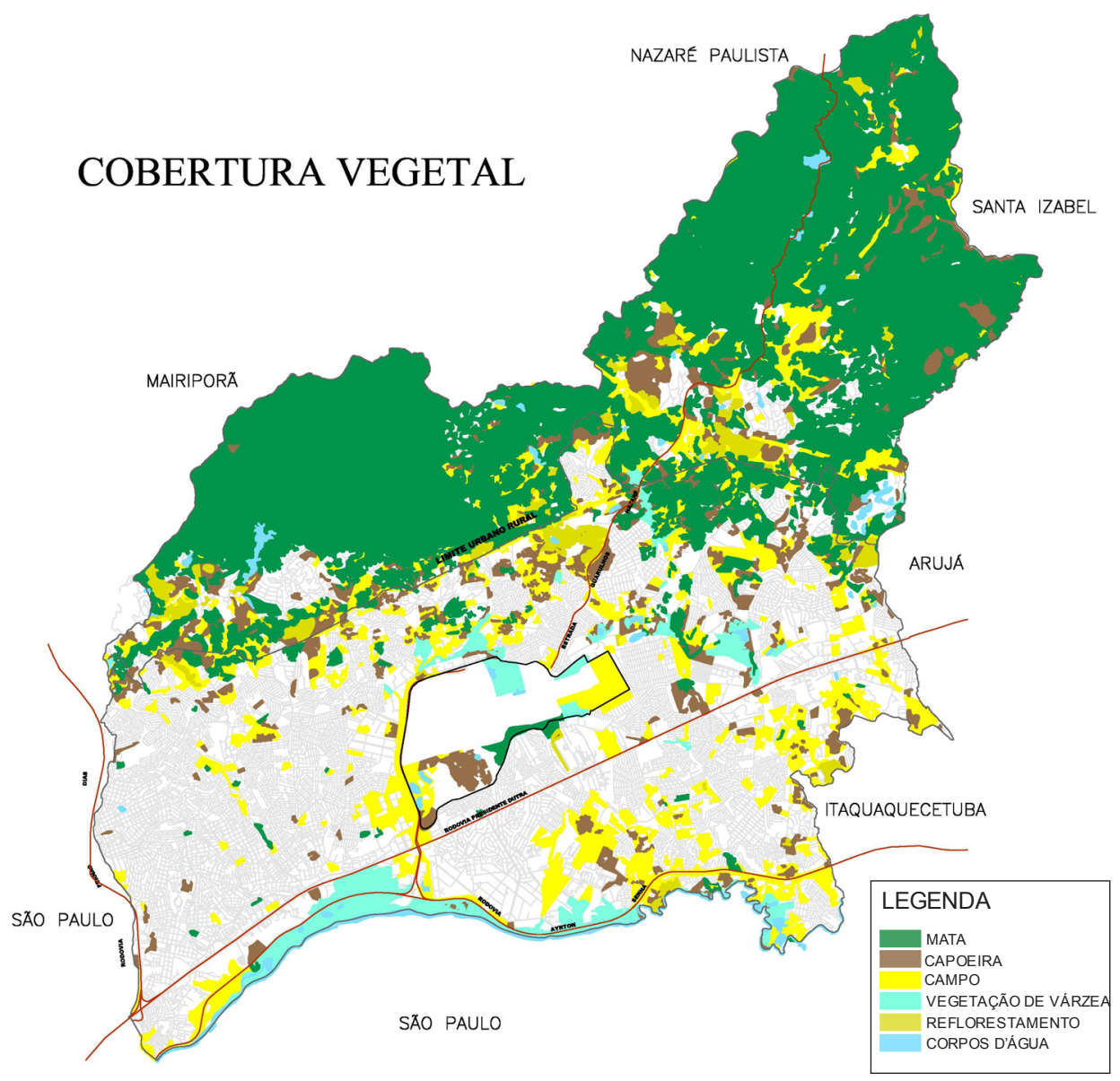

Mapa 6. Cobertura Vegetal do Município de Guarulhos. Fonte: PMG, 2008; EMPLASA, 2005, adaptado.

Segundo Ferreira (2006) apud Andrade (2009):

Os remanescentes florestais da mata atlântica encontrados na região da Cantareira e da APA do Cabuçu-Tanque Grande, representam parte de um importante corredor ecológico com eixo principal estabelecido na direção da Serra da Mantiqueira, e ainda alguns ramos em franco processo de fragmentação, encontrados especialmente na direção a Serra do Mar e do interior paulista.

De acordo com o Ministério do Meio Ambiente (2002; 2007), as principais ameaças à sobrevivência do bioma estão relacionadas aos loteamentos irregulares, as estradas e, no caso específico de Guarulhos, à construção do trecho norte do Rodoanel. A respeito dos impactos causados por esta construção, Mazzei et al (2011) sugere como principais riscos sobre a vegetação:

Redução da cobertura vegetal na área diretamente afetada; Risco de supressão de espécies protegidas e/ou em listas ameaçadas de extinção; Ampliação do grau de fragmentação florestal e instalação do efeito de borda; Alteração no nível de risco da ocorrência de incêndios 
nas florestas remanescentes no entorno da rodovia; Risco de alteração da estrutura e diversidade das florestas do PEC adjacente à rodovia. (Mazzei et al 2011, pg. 10)

Quando comparamos o Mapa 6 com o Mapa 11, podemos notar a presença quase que total da Mata Atlântica na porção norte do município, dominada por relevo mais dissecado e de maior altitude, isto é, áreas menos favoráveis à ocupação urbana. Contudo, também podemos notar uma nítida fragmentação da mancha florestal do município, principalmente nas poucas áreas remanescentes em zonas de relevo mais plano.

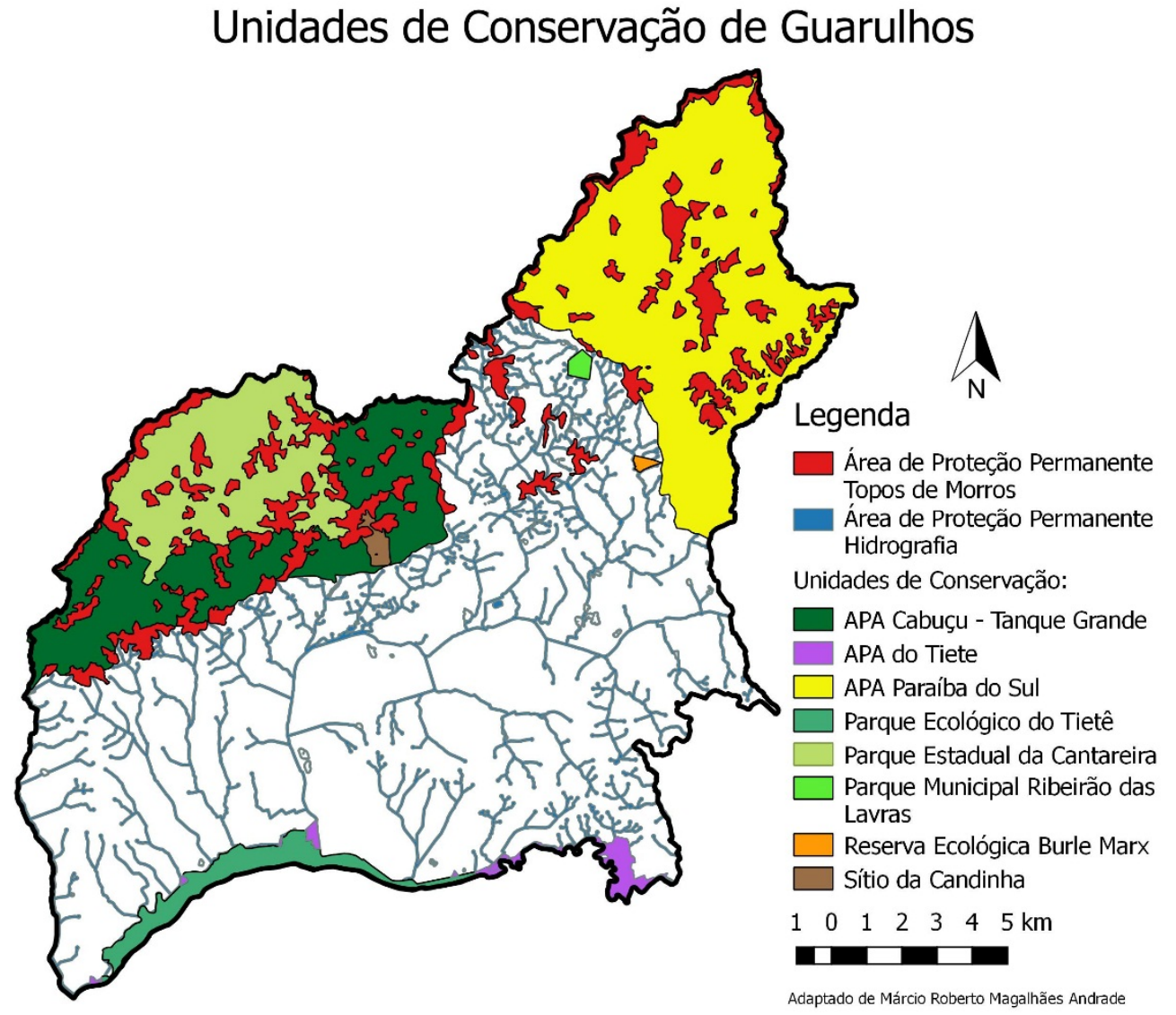

Mapa 7. Unidades de Conservação de Guarulhos.

Ainda assim, o município de Guarulhos possui oito grandes áreas de proteção ambiental e uso restrito, ocupando um total de mais de $120 \mathrm{~km}^{2}$ do município, ou $38 \%$ de sua área total. Como é possível observar no mapa 7, a administração dessas áreas de proteção ambiental está dividida entre as esferas estadual e municipal, conferindo diferentes restrições para o uso e ocupação de seu território.

O avanço da urbanização, principalmente de loteamentos clandestinos, tem reduzido os maciços florestais, demonstrando a necessidade de demarcação de 
novas áreas de proteção, melhor planejamento ou simplesmente de fiscalização mais efetiva.

\section{Hidrografia}

O território do Município de Guarulhos está localizado nas seguintes bacias hidrográficas: Jaguari, Cabuçu de Cima, Canal de Circunvalação, Baquirivu Guaçu, Tietê e uma série de pequenas bacias que deságuam diretamente no rio Tietê. Destas bacias, apenas Jaguari não faz parte do sistema Alto Tietê, pertencendo à Bacia Interestadual do Rio Paraíba do Sul.

A bacia do Canal de Circunvalação e a bacia dos pequenos tributários do Tietê estão totalmente localizadas no território do município, sendo as demais (Cabuçu de Cima e Baquirivu Guaçu) compartilhadas com outros municípios vizinhos, conforme mostra o Mapa 8:

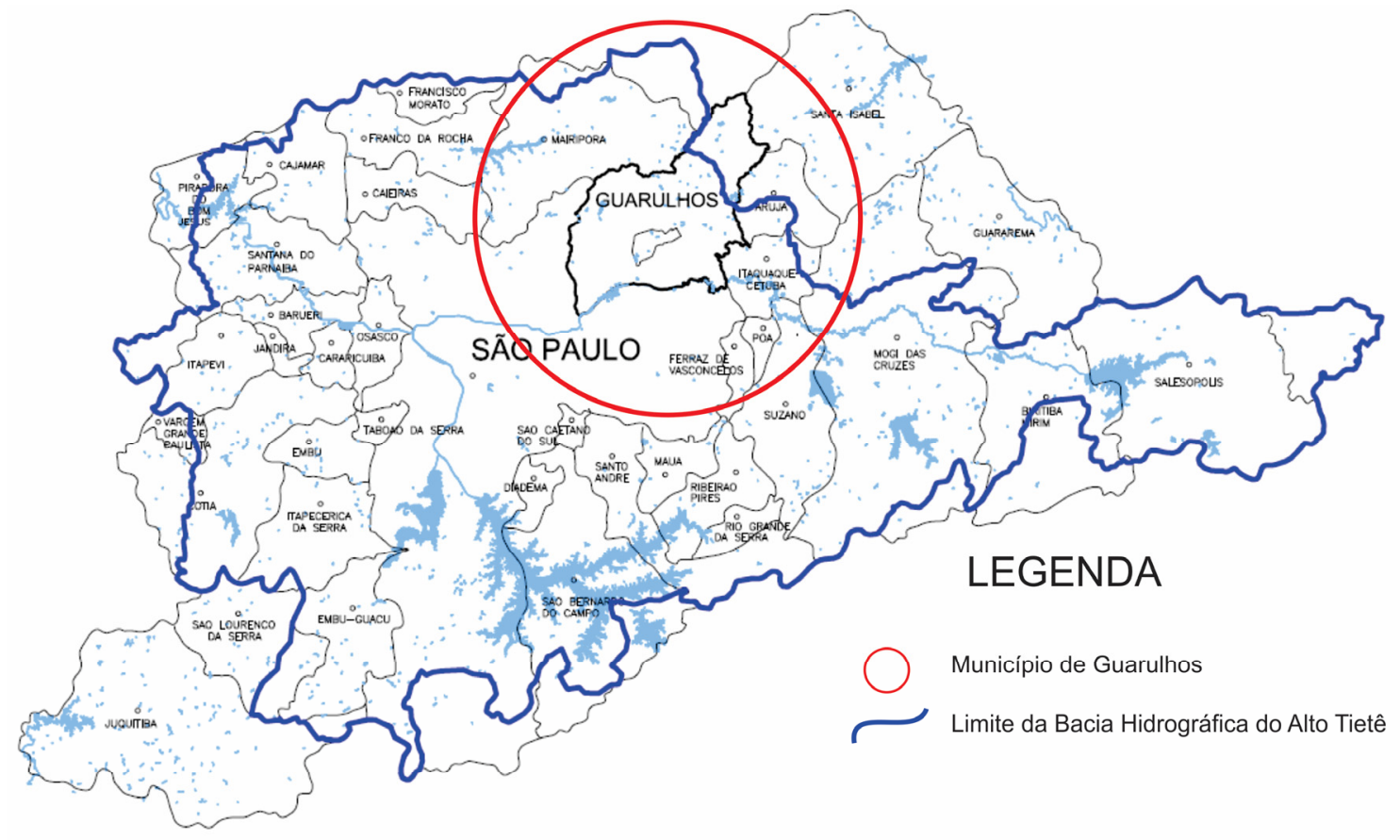

Fonte: Mapa de Uso e Ocupação do Solo da RMSP e Bacia Hidrográfica do Alto Tietê. EMPLASA, 2005, adaptado. Sem escala.

Mapa 8. Bacia do Alto Tietê e RMSP

Estes limites definem as responsabilidades e atribuições do Município na gestão dos recursos hídricos. Guarulhos tem como responsabilidade a proteção ambiental e a fiscalização sobre ocupações irregulares na Bacia do Jaguari por se tratar de uma bacia de nível nacional, o que gera vantagens ao município, como o 
direito de aproveitamento de suas águas para o abastecimento, desde que seja negociado com o Comitê de Bacia do Paraíba do Sul.

No que diz respeito a Bacia do Alto Tietê, Guarulhos participa do Sub Comitê Tietê Cabeceiras junto de Arujá, Itaquaquecetuba, Ferraz de Vasconcelos, Poá, Suzano, Mogi das Cruzes, Biritiba-Mirim e Salesópolis.

Para o abastecimento de sua população, Guarulhos possui uma autarquia municipal chamada Serviço Autônomo de Água e Esgoto - SAAE - que utiliza os recursos hídricos superficiais e subterrâneos através de barragens para captação (Cabuçu-Tanque Grande) e de poços sob o regime de outorga (PMG, 2008).

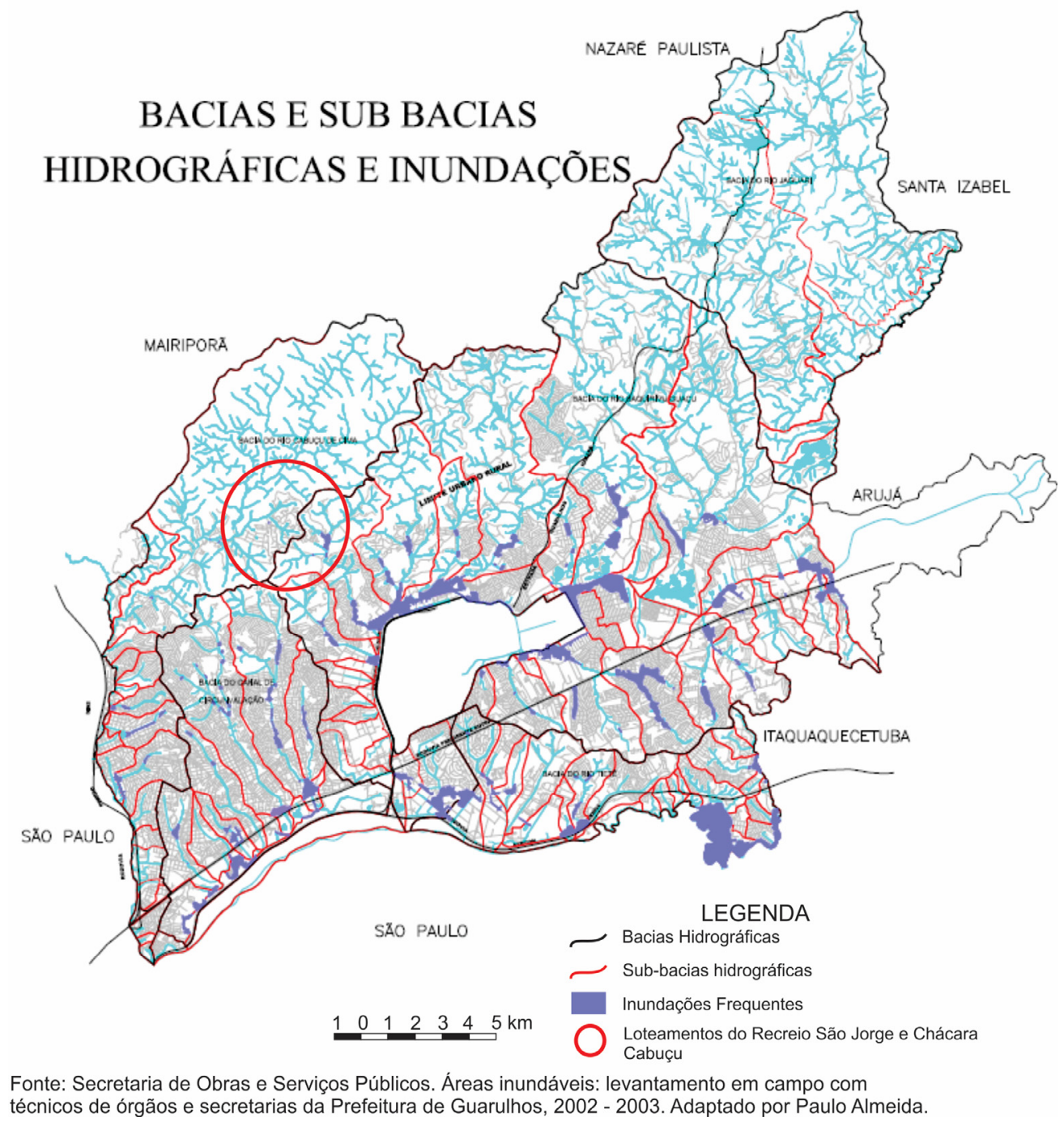

Mapa 9. Bacias e Sub-bacias Hidrográficas do Município de Guarulhos

Ainda assim, praticamente $88 \%$ da água utilizada para o abastecimento do município é adquirida em atacado da Companhia de Saneamento Básico do Estado de São Paulo - SABESP - por intermédio do Sistema Adutor Metropolitano (55\% a 
proveniente do Sistema Cantareira e 33\% do Sistema Alto Tietê) devido à insuficiência dos sistemas municipais em atender à demanda de consumo.

\section{Geologia}

Segundo Andrade (2009, pg. 77-78), a geologia da RMSP:

A RMSP insere-se no contexto geotectônico da Região de Dobramentos Sudeste (HASUI et al, 1978), mais especificamente relacionada ao Orógeno Ribeira integrante da Província Mantiqueira (ALMEIDA et al, 1977; 1981) desenvolvida durante a Orogenia Neoproterozóica Brasiliano-Pan Africana (Ciclo Brasiliano) que teve início em torno de $880 \mathrm{Ma}$ e findou há cerca de $480 \mathrm{Ma}$, resultando na amalgamação do Paleocontinente Gondwana Ocidental, e estruturação do embasamento da Plataforma Sul-Americana (BRITONEVES et al, 1999). O Orógeno Ribeira resultou da interação entre o Cráton do São Francisco e outra(s) placa(s) e/ou microplaca(s) e/ou arco de ilhas situado(s) a sudeste deste Cráton, bem como com a porção sudoeste do Cráton do Congo. A colisão entre terrenos foi oblíqua e a deformação principal exibe clara partição entre zonas com predomínio de encurtamento frontal e zonas com componente transpressivo destral. A intensa deformação resultante desta colisão originou dobras apertadas a isoclinais, forte xistosidade, muitas vezes milonítica, e lineação de estiramento. As zonas de cisalhamento dúcteis resultantes são orientadas segundo E-NE a E-W(HEILBRON, et. al., 2004).

Após esse evento, houve uma reativação tectônica meso-cenozóica denominada evento Sul Atlantiano (SCHOBBENHAUS et al, 1984 apud Andrade, 2009), que deu origem à ruptura da Gondwana e iniciou a separação entre as placas Sul-Americana e Africana, gerando a fragmentação do continente, arqueamentos, derrames basálticos e a geração de rift valleys.

A RMSP está localizada parcialmente no Rift Continental do Sudeste do Brasil (RCSB), com características tectônicas do tipo hemi-gráben, associadas a abertura do Oceano Atlântico, formando uma bacia alongada e deprimida, paralela a $70 \mathrm{~km}$ da linha atual da costa litorânea, no sentido E-NE (RICCOMINI et al, 2004 apud ANDRADE, 2009).

No período Terciário ocorreu a sedimentação de origem continental sobre terrenos pré-cambrianos, dando origem a Bacia Sedimentar de São Paulo, que teve sua fase mais significativa de desenvolvimento no Eoceno-Oligoceno, terminando por volta do Mioceno. A sedimentação atual, originada no Quaternário, tem ocorrido de maneira mais reduzida devido à predominância de processos erosivos associados, 
principalmente, aos níveis de base do Rio Tietê e Paraíba do Sul. Contudo, esses processos têm causado o intemperismo, a pedogênese e a formação de colúvios de forma mais ampla.

O Mapa 10 representa o embasamento geológico do município de Guarulhos:

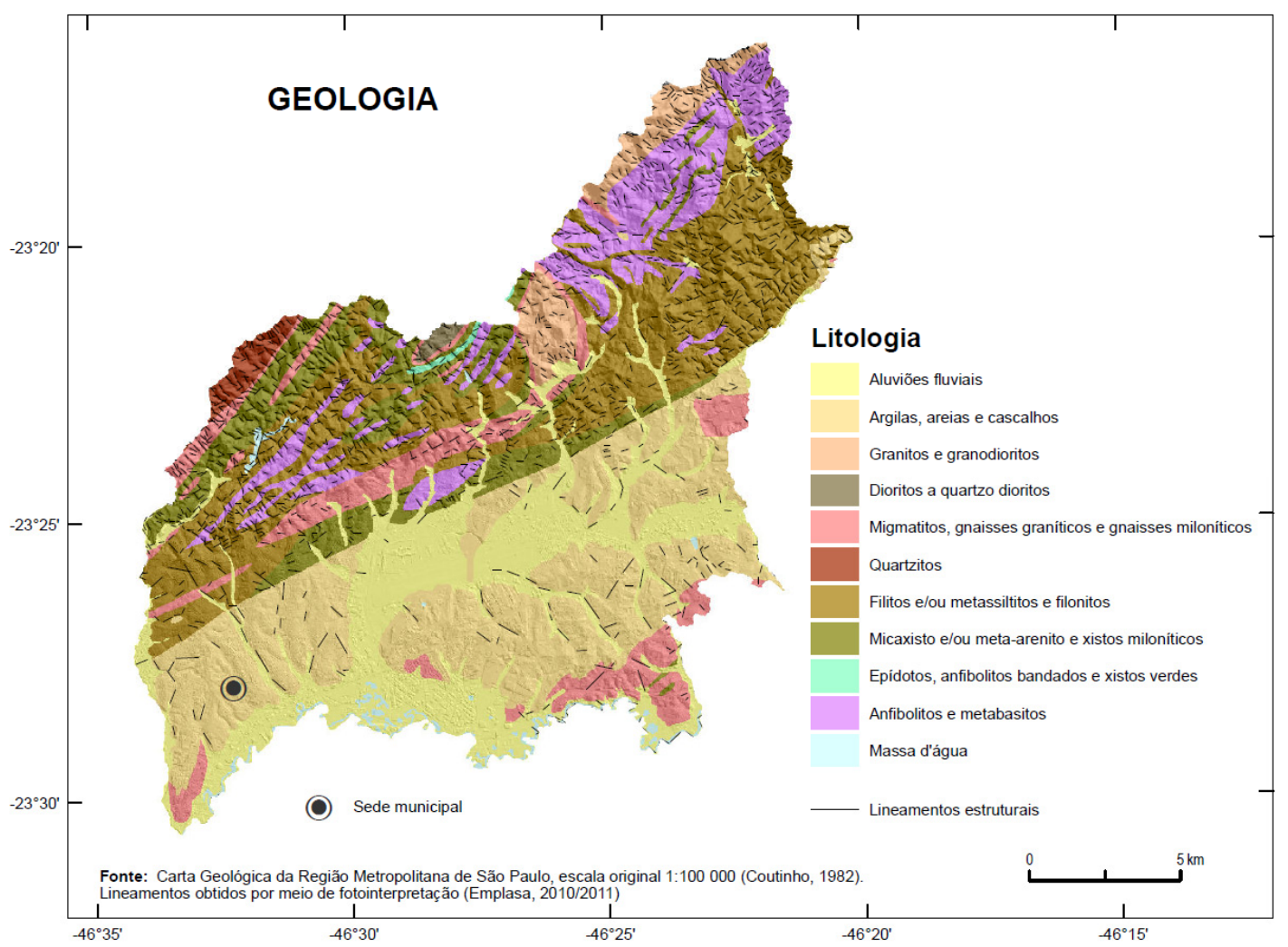

Mapa 10. Geologia do Município de Guarulhos

Conforme podemos observar, o território do município está assentado, principalmente, sobre terrenos terciários e quaternários formados por aluviões fluviais, argilas, areias e cascalhos na porção mais meridional de seu território (processos terciários e quaternários). Contudo, sua porção setentrional está sobre um embasamento formado, principalmente, por micaxistos, meta-arenitos, filitos, quartizitos, entre outros, originários dos processos de dobramentos que deram origem ao conjunto da Serra da Cantareira e Serra do Itaberaba.

Nesse sentido, a complexidade geológica permite um potencial de recursos minerais a serem explorados, seja no complexo cristalino ou no complexo sedimentar, fato este revelado na própria origem do povoamento colonizador do século XVI na região, baseado na extração aurífera, ou no final do século XIX e início do XX, com a exploração de argilas e areias para a construção civil.

Podemos notar, portanto, dois complexos paisagísticos baseados nas formações geológicas da região: de um lado os grandes blocos tectônicos que 
formaram o complexo serrano na periferia ao norte do município, abrigo atual dos últimos remanescentes de Mata Atlântica e dos mananciais da região; do outro, as planícies aluviais ocupadas pelas áreas urbanas de maior apropriação e transformação do espaço geográfico.

Ambas as áreas estão associadas a dois processos distintos: as deformações pré-cambrianas do Ciclo Brasiliano, reativadas no Ciclo Atlantiano; e as deposições dos sedimentos terciários e quaternários que resultaram na atual conformação da paisagem natural.

Além disso, é localizada na região a falha transcorrente do Jaguari, que se encontra no centro do território do município, em sentido SW-NE; nesta mesma direção ainda existem as falhas dos Veigas e do Cabuçu, além de falhamentos menores de direção N-S.

\section{Geomorfologia}

Guarulhos está localizada no domínio do Planalto Atlântico, dominado pelas seguintes formações: várzeas, planícies aluviais, colinas, morros e serras. O ponto de maior altitude do município é o Pico do Gil, situado a 1.422m acima no nível do mar, no Espigão da Serra de Itaberaba. A foz do Ribeirão Jaguari, localizado no limite entre Guarulhos, Santa Isabel e Arujá é o ponto mais baixo, situado a $660 \mathrm{~m}$ de altitude.

Para Almeida (1964) apud Andrade (2009, pg.80):

A compartimentação do relevo nesta região deve-se sobremaneira a uma estruturação geológica que se manifesta em grande escala na definição dos contornos da costa sudeste brasileira, como em média escala na compartimentação de blocos estruturais com centenas de metros a alguns kilometros de extensão, expressão de ciclos tectônicos diversos que deformaram a crosta terrestre.

Segundo Ross (2006), a RMSP está localizada na unidade geomorfológica do Macrocompartimento dos Planaltos e Serras do Atlântico Leste-Sudeste, como morfoestrutura de cinturões orogenéticos e núcleos cristalinos arqueados, conforme a Tabela 1: 
Tabela 1. Características geomorfológicas dos Planaltos e Serras do Atlântico Leste-Sudeste (ROSS, 2006 apud ANDRADE, 2009).

\begin{tabular}{|c|c|c|c|}
\hline Formas de relevo & Altitude (m) & Litologias & Solos \\
\hline $\begin{array}{l}\text { Serras e morros alongados - } \\
\text { relevo montanhoso- } \\
\text { batólitos }\end{array}$ & $\begin{array}{c}900-1400 \\
2600\end{array}$ & $\begin{array}{l}\text { Gnaisses, migmatitos, } \\
\text { micaxistos, filitos, quartzitos, }\end{array}$ & $\begin{array}{l}\text { Neossolos litólicos } \\
\text { Neossolos câmbicos } \\
\text { Argissolos vermelhos }\end{array}$ \\
\hline $\begin{array}{l}\text { Escarpas estruturais/falhas } \\
\text { Superfícies de morros de topos } \\
\text { convexos }\end{array}$ & $800-900$ & $\begin{array}{l}\text { Granitos, sienitos, fenolitos, } \\
\text { calcáreos, mármores }\end{array}$ & $\begin{array}{l}\text { Afloramentos rochosos } \\
\text { Latossolos vermelho- } \\
\text { amarelos }\end{array}$ \\
\hline $\begin{array}{l}\text { Depressões } \\
\text { cenozóicas }\end{array}$ & $600-800$ & $\begin{array}{l}\text { arenitos, argilitos, cascalhos e } \\
\text { folhelhos }\end{array}$ & \\
\hline
\end{tabular}

Para Ab'Saber (1966; 2003), a RMSP está localizada no Domínio Morfoclimático dos Mares de Morros Florestados, tendo como características gerais o predomínio de relevos com formas mamelonadas, encontrados em todos os níveis topográficos, inclusive nas depressões intermontanas, mascarando as superfícies erosivas, os terraços e os níveis de pedimentação e com espessos horizontes de alteração. $\mathrm{O}$ autor ainda destaca a presença das planícies fluviais com seus canais meândricos, formadas predominantemente por sedimentos finos e a presença dos colúvios que soterram as linhas de pedra. As temperaturas elevadas e os períodos seco e úmido bem definidos, com precipitações anuais acima dos $1100 \mathrm{~mm}$, concentradas entre os meses de dezembro e março, permitindo a formação de florestas tropicais decíduas e semidecíduas e a presença de alguns enclaves de boques de araucárias e manchas de cerrado.

Se compararmos o Mapa 11 com o Mapa 10, podemos notar uma nítida associação entre suas formações. Nas áreas de predomínio do relevo de colinas e planícies aluviais, na porção centro-sul do município encontra-se também a área de predomínio dos sedimentos Terciários e Quaternários da Bacia de São Paulo, ocorrendo ainda pequenos afloramentos de rochas cristalinas. Já nas formações de Morros Baixos e Altos e de Serras, ocorrem as formações geológicas de origem cristalina, associadas aos Ciclos Brasiliano e Atlantiano, localizadas ao norte do município. 


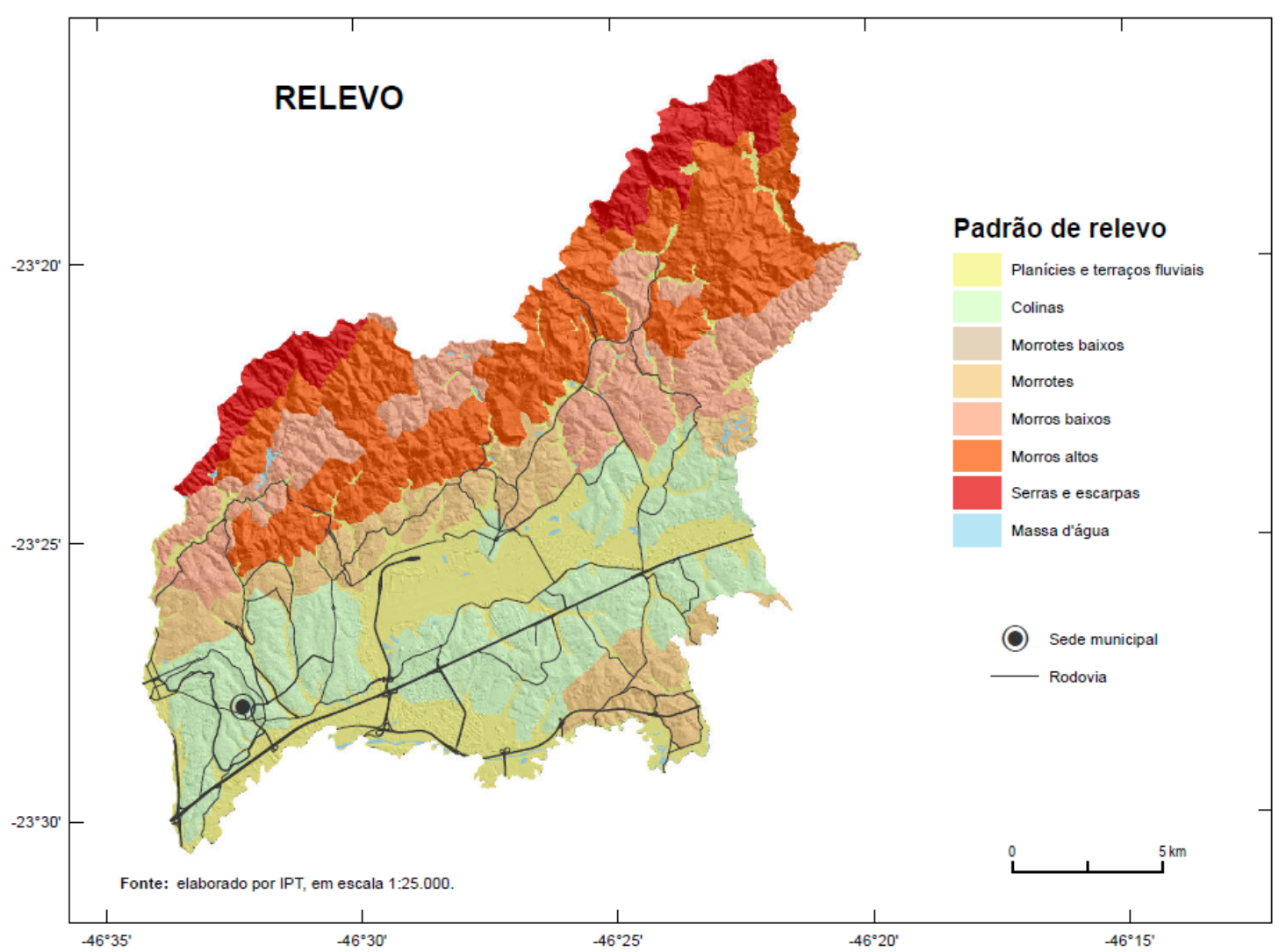

Mapa 11. Padrões de Relevo do Município de Guarulhos

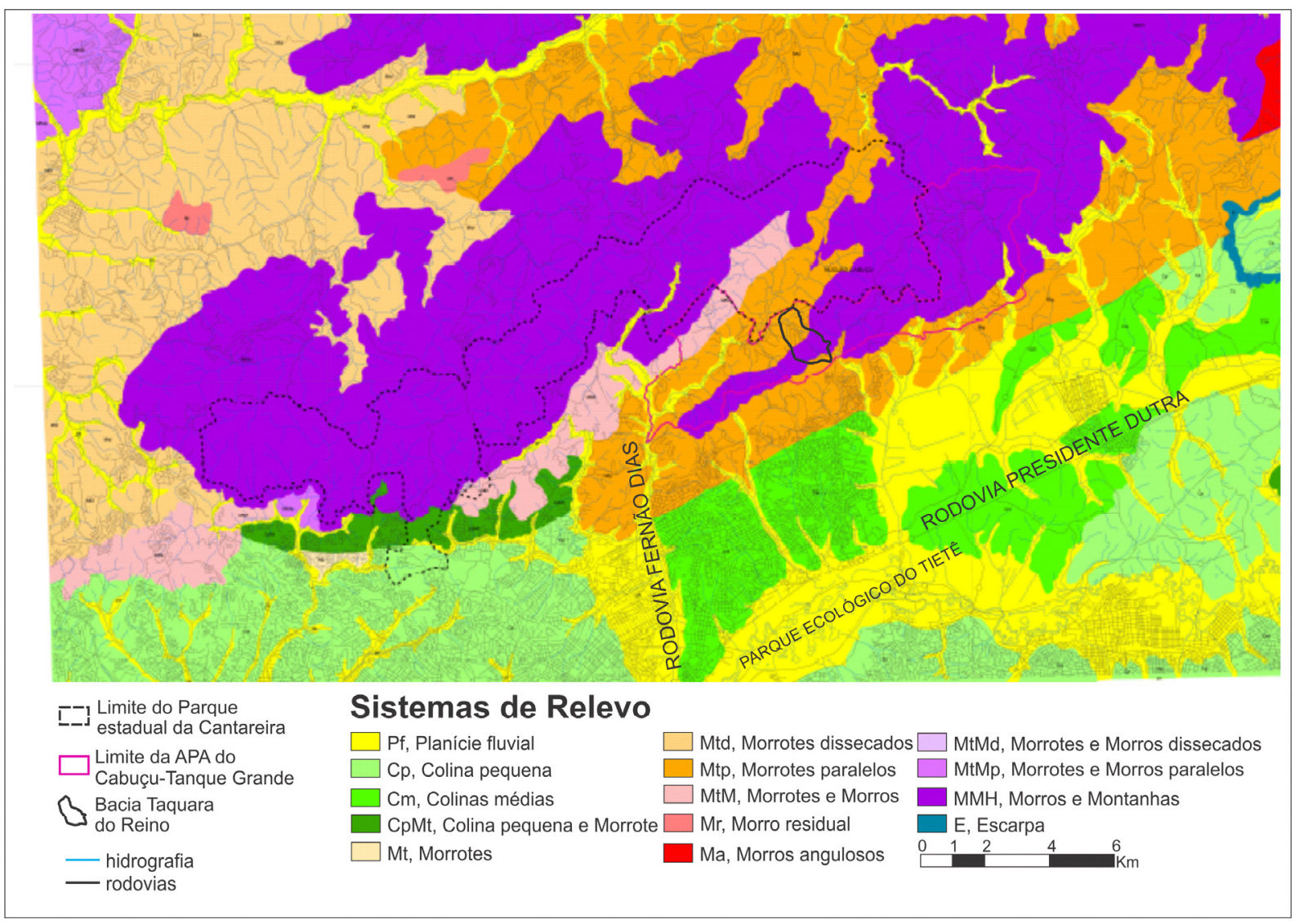

Mapa 12. Recorte do Mapa Geomorfológico do Parque Estadual da Cantareira e APA do Cabuçu-Tanque Grande. Fonte: Andrade, 2009 adaptado. 
Segundo Andrade (2009), o Mapa 12 permite a identificação de 13 formas de relevo nas áreas do Parque Estadual da Cantareira e da APA do Cabuçu-Taque Grande, conforme destaca Andrade (2009, pg. 82):

Cujo arranjo espacial configura a presença de blocos morfoestruturais desnivelados e de depressões intermontanas subniveladas por superfícies erosivas locais, nas quais ocorrem depósitos detríticos cenozóicos e amplas planícies aluviais associadas aos rios Tietê, Baquirivu-guaçu e Juqueri.

A esse respeito, Andrade (2009, p. 83) elaborou uma tabela com a caracterização das formas de relevo encontradas na área:

Tabela 2. Sistemas de relevo e respectivas características morfométricas e morfográficas das folhas Guarulhos e Itaquaquecetuba 1:50.000 (ANDRADE, 2009, com base em OLIVEIRA et al, 2005):

\begin{tabular}{|c|c|c|}
\hline $\begin{array}{l}\text { TIPO DE } \\
\text { RELEVO }\end{array}$ & MORFOMETRIA & MORFOGRAFIA \\
\hline $\begin{array}{l}\text { Planícies de } \\
\text { inundação e } \\
\text { Terraços } \\
\text { Baixos (Pf) }\end{array}$ & $\begin{array}{l}\text { Inclinação: Inferior a } \\
\qquad 1,5 \% \\
\text { Elevados } 3 \text { a } 6 \text { m acima } \\
\text { do rio }\end{array}$ & $\begin{array}{l}\text { Terrenos planos e inclinados em direção ao rio, compreendendo a Planície } \\
\text { de Inundação e Terraços Baixos. Associam-se alagadiços e canais } \\
\text { abandonados. }\end{array}$ \\
\hline $\begin{array}{c}\text { Colinas } \\
\text { médias }(\mathrm{Cm})\end{array}$ & $\begin{array}{l}\text { Amplitude: } 25 \text { a } 40 \text { m } \\
\text { Comp. Rampa: } 500 \text { a } \\
\qquad 900 \text { m } \\
\text { Inclinação: } 3 \% \text { a } 5 \%\end{array}$ & $\begin{array}{l}\text { Colinas de topos subhorizontais amplos. Vertentes de perfil contínuo, com } \\
\text { segmentos retilíneos a convexos. Vales erosivos abertos e bem marcados } \\
\text { no relevo. O padrão de drenagem é sub-dendrítico de baixa a média } \\
\text { densidade. }\end{array}$ \\
\hline $\begin{array}{l}\text { Colinas } \\
\text { pequenas } \\
\text { (Cp) }\end{array}$ & $\begin{array}{l}\text { Amplitude: } 20 \text { a } 40 \text { m } \\
\text { Comp. Rampa: } 300 \text { a } \\
\qquad 600 \text { m } \\
\text { Inclinação: } 6 \% \text { a } 13 \%\end{array}$ & $\begin{array}{l}\text { Colinas de topos estreitos convexos. Vertentes de perfil contínuo, com } \\
\text { segmentos retilíneos a convexos. Vales erosivos abertos e bem marcados } \\
\text { no relevo. O padrão de drenagem é sub-dendrítico de baixa a média } \\
\text { densidade. }\end{array}$ \\
\hline $\begin{array}{l}\text { Colinas } \\
\text { pequenas e } \\
\text { Morrotes } \\
\text { (CpMt) }\end{array}$ & $\begin{array}{l}\text { Amplitude: } 25 \text { a } 60 \text { m } \\
\text { Comp. Rampa: } 200 \text { a } \\
\qquad 450 \text { m } \\
\text { Inclinação: } 10 \% \text { a } 20 \%\end{array}$ & $\begin{array}{l}\text { Associam-se colinas e morrotes de topos estreitos convexos. Perfil de } \\
\text { vertente contínuo e descontínuo com segmentos convexos e retilíneos, } \\
\text { podendo ser mais íngrime nas nascentes. Vales erosivos-acumulativos } \\
\text { encaixados e acumulativos abertos, com planícies estreitas e contínuas. } \\
\text { Canais aluviais meândricos e retilíneos. O padrão de drenagem é } \\
\text { subdendrítico de baixa a média densidade. }\end{array}$ \\
\hline Morrotes (Mt) & $\begin{array}{l}\text { Amplitude: } 40 \text { a } 90 \text { m } \\
\text { Comp. rampa: } 200 \text { a } \\
\qquad 500 \text { m } \\
\text { Inclinação: } 12 \% \text { a } 25 \%\end{array}$ & $\begin{array}{l}\text { Formas niveladas. Topos estreitos e convexos. Perfil de vertente contínuo } \\
\text { com segmentos retilíneos. Vales erosivos abertos. Padrão de drenagem } \\
\text { subdendrítico de média densidade. }\end{array}$ \\
\hline $\begin{array}{l}\text { Morrotes } \\
\text { paralelos } \\
\text { (MTp) }\end{array}$ & $\begin{array}{l}\text { Amplitude: } 30 \text { a } 90 \text { m } \\
\text { Comp. rampa: } 200 \text { a } \\
600 \text { m } \\
\text { Inclinação: } 10 \% \text { a } 30 \%\end{array}$ & $\begin{array}{l}\text { Formas niveladas. Topos estreitos, convexos e alongados na direção } \\
\text { nordeste. Perfil de vertente contínuo com segmentos retilíneos ou } \\
\text { convexos. Vales erosivos encaixados. Canais em rocha e blocos. Padrão } \\
\text { de drenagem treliça e paralelo de alta densidade. }\end{array}$ \\
\hline
\end{tabular}




\begin{tabular}{|c|c|c|}
\hline $\begin{array}{c}\text { Morrotes } \\
\text { dissecados } \\
\text { (MTd) }\end{array}$ & $\begin{array}{l}\text { Amplitude: } 50 \text { a } 80 \text { m } \\
\text { Comp. Rampa: } 200 \text { a } \\
\qquad 600 \text { m } \\
\text { Inclinação: } 12 \% \text { a } 30 \%\end{array}$ & $\begin{array}{l}\text { Formas niveladas. Topos estreitos e convexos. Perfil de vertente contínuo } \\
\text { com segmentos retilíneos ou convexos. Vales erosivos-acumulativos } \\
\text { encaixados e acumulativos abertos. Canais em rocha, blocos e em aluviões } \\
\text { nas planícies contínuas com larguras de até } 500 \mathrm{~m} \text {. Padrão de drenagem } \\
\text { subdendritido de alta densidade. }\end{array}$ \\
\hline $\begin{array}{c}\text { Morrotes e } \\
\text { Morros (MtM) }\end{array}$ & $\begin{array}{l}\text { Amplitude: } 40 \text { a } 100 \text { m } \\
\text { Comp. Rampa: } 200 \text { a } \\
\qquad 500 \text { m } \\
\text { Inclinação: } 15 \% \text { a } 35 \%\end{array}$ & $\begin{array}{l}\text { Formas niveladas. Topos estreitos convexos. Perfil de vertente descontínuo } \\
\text { com segmentos retilíneos e convexos. Vales erosivos encaixado e } \\
\text { erosivosacumulativos abertos. Planícies fluviais estreitas e descontínuas. } \\
\text { Canais aluviais, em rocha e blocos. Padrão de drenagem subdendrítico e } \\
\text { subparalelo de média a alta densidade. }\end{array}$ \\
\hline $\begin{array}{l}\text { Morrotes e } \\
\text { Morros } \\
\text { paralelos } \\
\text { (MtMp) }\end{array}$ & $\begin{array}{l}\text { Amplitude:60 a } 140 \text { m } \\
\text { Comp. Rampa } 250 \text { a } \\
\qquad 500 \text { m } \\
\text { Inclinação: } 20 \% \text { a } 35 \%\end{array}$ & $\begin{array}{l}\text { Formas dissecadas. Topos estreitos e convexos e alongados na direção } \\
\text { nordeste. Perfil de vertente descontínuo com segmentos retilíneos e } \\
\text { convexos. Vales erosivos-acumulativos e acumulativos abertos. Planícies } \\
\text { fluviais estreitas e contínuas. Canais aluviais, em rocha e blocos Padrão de } \\
\text { drenagem em treliça e subdendrítico de alta densidade. }\end{array}$ \\
\hline $\begin{array}{l}\text { Morros } \\
\text { angulosos } \\
\text { (Ma) e } \\
\text { residuais (Mr) }\end{array}$ & $\begin{array}{l}\text { Amplitude: } 80 \text { a } 160 \text { m } \\
\text { Comp. Rampa } 150 \text { a } \\
\qquad 600 \text { m } \\
\text { Inclinação: } 20 \% \text { a } 55 \%\end{array}$ & $\begin{array}{l}\text { Formas desniveladas. Topos estreitos e agudo. Perfil de vertente } \\
\text { descontínuo com segmentos retilíneos, convexos e com afloramentos } \\
\text { rochosos nos segmentos mais íngremes. Vales erosivos encaixados, canais } \\
\text { em rocha e blocos. Padrão de drenagem em treliça e subdendrítico de alta } \\
\text { densidade. }\end{array}$ \\
\hline $\begin{array}{l}\text { Morros e } \\
\text { Montanhas } \\
\text { (MMH) }\end{array}$ & $\begin{array}{l}\text { Amplitude: } 120 \text { a } 420 \text { m } \\
\text { Comp. rampa: } 400 \text { a } \\
\qquad 1400 \text { m } \\
\text { Inclinação: } 20 \% \text { a } 40 \%\end{array}$ & $\begin{array}{l}\text { Formas maciças desniveladas. Topos estreitos agudos e rochosos por } \\
\text { vezes com picos isolados. Perfil de vertente descontínuo, segmentos longos } \\
\text { retilíneo, convexos e rochosos. Vales erosivos e muito encaixados. Canais } \\
\text { em rocha e blocos, com cachoeiras e rápidos. Planícies alveolares } \\
\text { localizadas a montante de soleiras. Canais de } 1^{a} \text { ordem pouco encaixados. } \\
\text { Densidade de drenagem média a alta, com padrão subdendritico e em } \\
\text { treliça. }\end{array}$ \\
\hline Escarpas (E) & $\begin{array}{l}\text { Amplitude: } 100 \text { a } 220 \mathrm{~m} \\
\text { Comp. rampa: } 300 \text { a } \\
\quad 600 \mathrm{~m} \\
\text { Inclinação: } 25 \% \text { a } 45 \%\end{array}$ & $\begin{array}{l}\text { Formas assimétrica e retilínea. Topos subnivelados com ruptura de declive } \\
\text { nítida. Perfil de vertente de continuo, retilíneo, íngreme e rochosos, ou } \\
\text { descontinuo com segmentos convexos devido à presença de corpos de } \\
\text { tálus. Vales erosivos, pouco encaixados, canais em rocha com cachoeiras e } \\
\text { rápidos. Densidade de drenagem baixa. }\end{array}$ \\
\hline
\end{tabular}

Segundo Ab'saber (2003), as características das formações do domínio dos mares de morros do Brasil Tropical Atlântico, onde se situa a Bacia de São Paulo, é "o meio físico mais complexo e difícil do país em relação às construções e ações humanas", onde podem ocorrer "os mais fortes processos de erosão e de movimentos coletivos de solos de todo o território brasileiro." (AB'SABER, 2003, pg. 62).

Para Nakazawa (1994) apud Andrade (2009, pg. 84-85), é possível relacionar cada sistema de relevo a um comportamento geotécnico, resumido nas seguintes categorias:

- Morros e montanhas - alta suscetibilidade a escorregamentos (naturais e induzidos) e alta suscetibilidade à erosão nos solos subsuperficiais, induzida por movimentos de terra;

- Morros e morrotes - média suscetibilidade a escorregamentos (exclusivamente induzidos) e alta suscetibilidade à erosão nos solos subsuperficiais, induzida por movimentos de terra; 
- Colinas e morrotes - baixas suscetibilidades aos processos do meio físico analisados;

- Planícies aluviais - alta suscetibilidade à inundações, recalques, assoreamentos, solapamentos das margens dos rios.

Essa configuração geomorfológica-geológica tem influência direta nos padrões de escoamento superficial, na capacidade de infiltração e armazenamento das águas subterrâneas (aquíferos) e, principalmente, nos processos erosivos, conforme mostram os mapas abaixo:

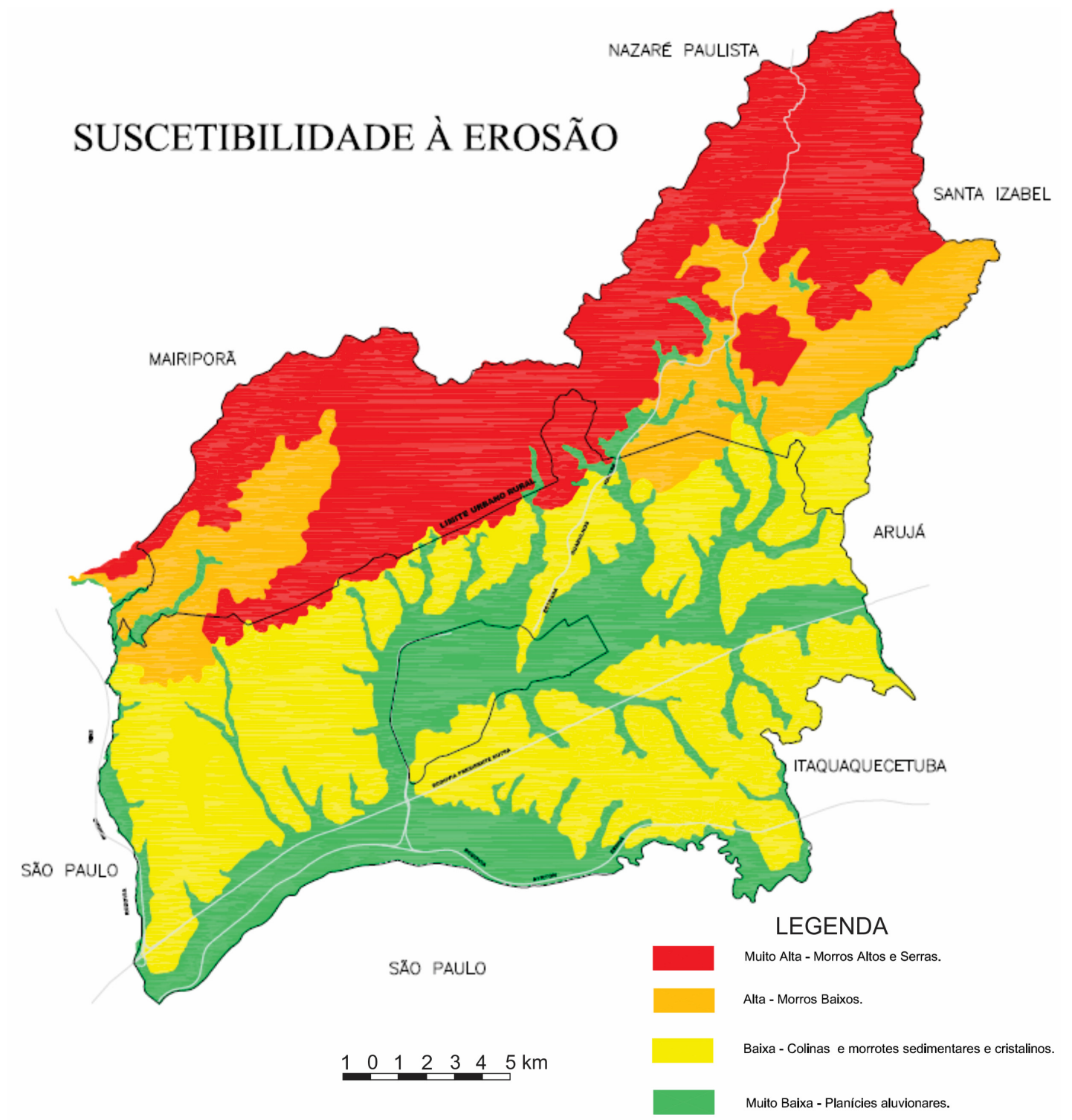

Fonte: Secretaria do Meio Ambiente adaptado de ANDRADE, 2001. Laboratório de Cartografia - FFLCH/USP Base: EMPLASA - Levantamento Aerofotogramétrico, 1:50000, 1979

Mapa 13. Suscetibilidade à Erosão

Como já destacado anteriormente, as áreas de maior suscetibilidade à erosão estão localizadas, via de regra, nas áreas de maior declividade do município, 
diminuindo a suscetibilidade em direção aos terrenos mais planos. Obviamente, as variáveis que estão em jogo nesses processos são a elevação, a declividade e a força da gravidade. Para uma análise mais detalhada, seria necessário elaborar uma carta de feições mínimas do relevo.

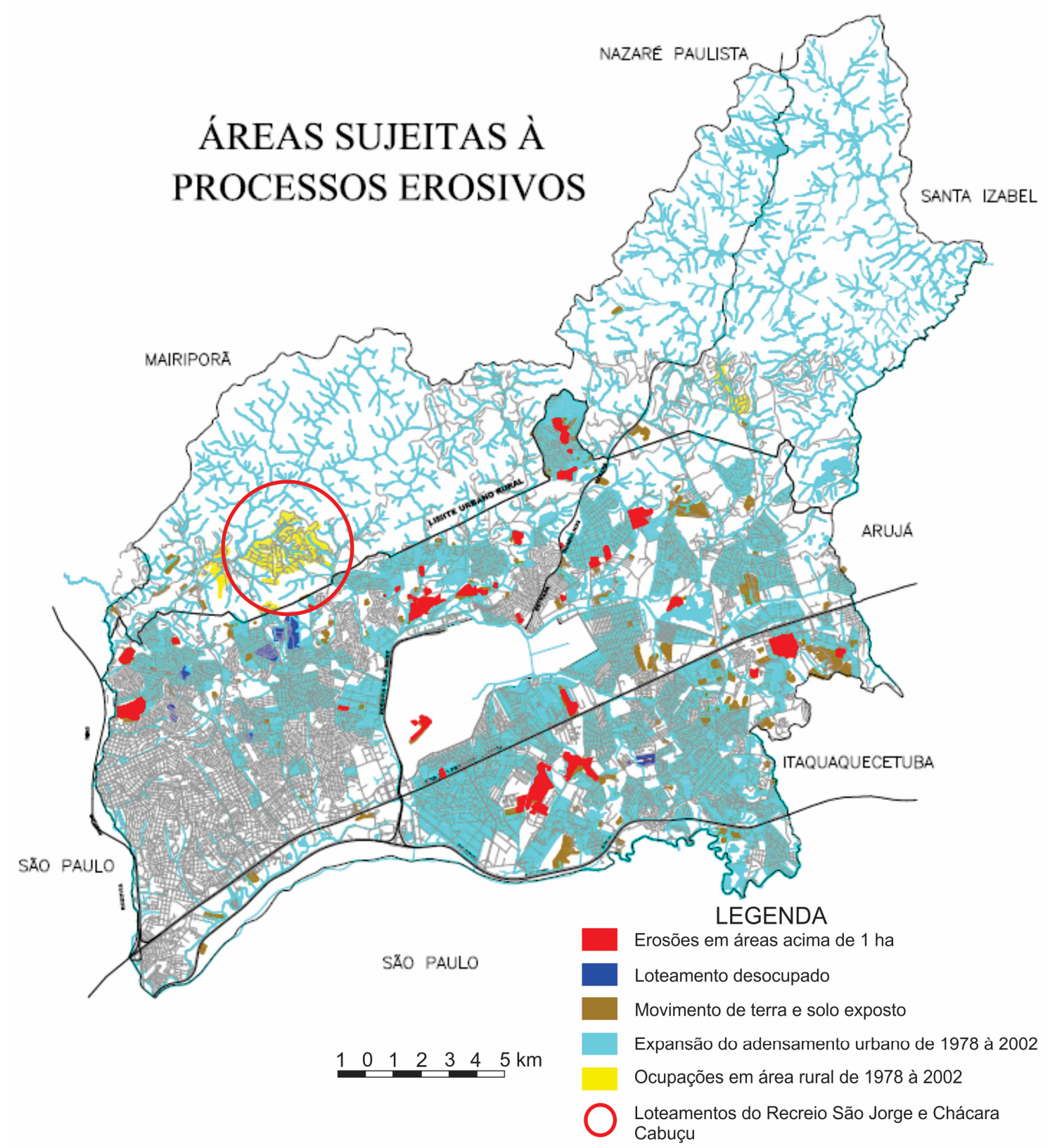

Fonte: Secretaria de Meio Ambiente de Guarulhos; Mapa de Uso e Ocupação do Solo da RMSP e Bacia Hidrográfica do Alto Tietê, EMPLASA, jun/2005; Secretaria de Desenvolvimento Urbano de Guarulhos.

Mapa 14. Áreas Sujeitas a Processos Erosivos

Ao analisarmos os Mapas 13 e 14, podemos notar que não há uma relação direta entre as áreas suscetíveis à erosão (Mapa 13) e as áreas que estão sujeitas aos processos erosivos (Mapa 14). Neste caso, as áreas de maior suscetibilidade estão nos terrenos de maior declividade, em sua maior parte localizados ao norte do 
município, nas áreas de dobramentos e maciços cristalinos. Contudo, essa suscetibilidade é apenas potencial, podendo ou não se concretizar em fenômenos de movimentos gravitacionais de massa.

Como é possível observar, as principais áreas de sujeição aos processos erosivos estão, geralmente, em áreas já urbanizadas ou em vias de urbanização e ocupação, na maioria das vezes irregular, de loteamentos nos terrenos de maior declividade sendo, portanto, a ocupação humana (nessa modalidade de ocupação irregular, alheia ao planejamento) o fator que ativa os processos erosivos que antes eram apenas potenciais. Para melhor visualizar essa relação, o Mapa 15 mostra a declividade dos terrenos do município, com destaque para a área de estudo do loteamento do Recreio São Jorge, no bairro do Cabuçu:

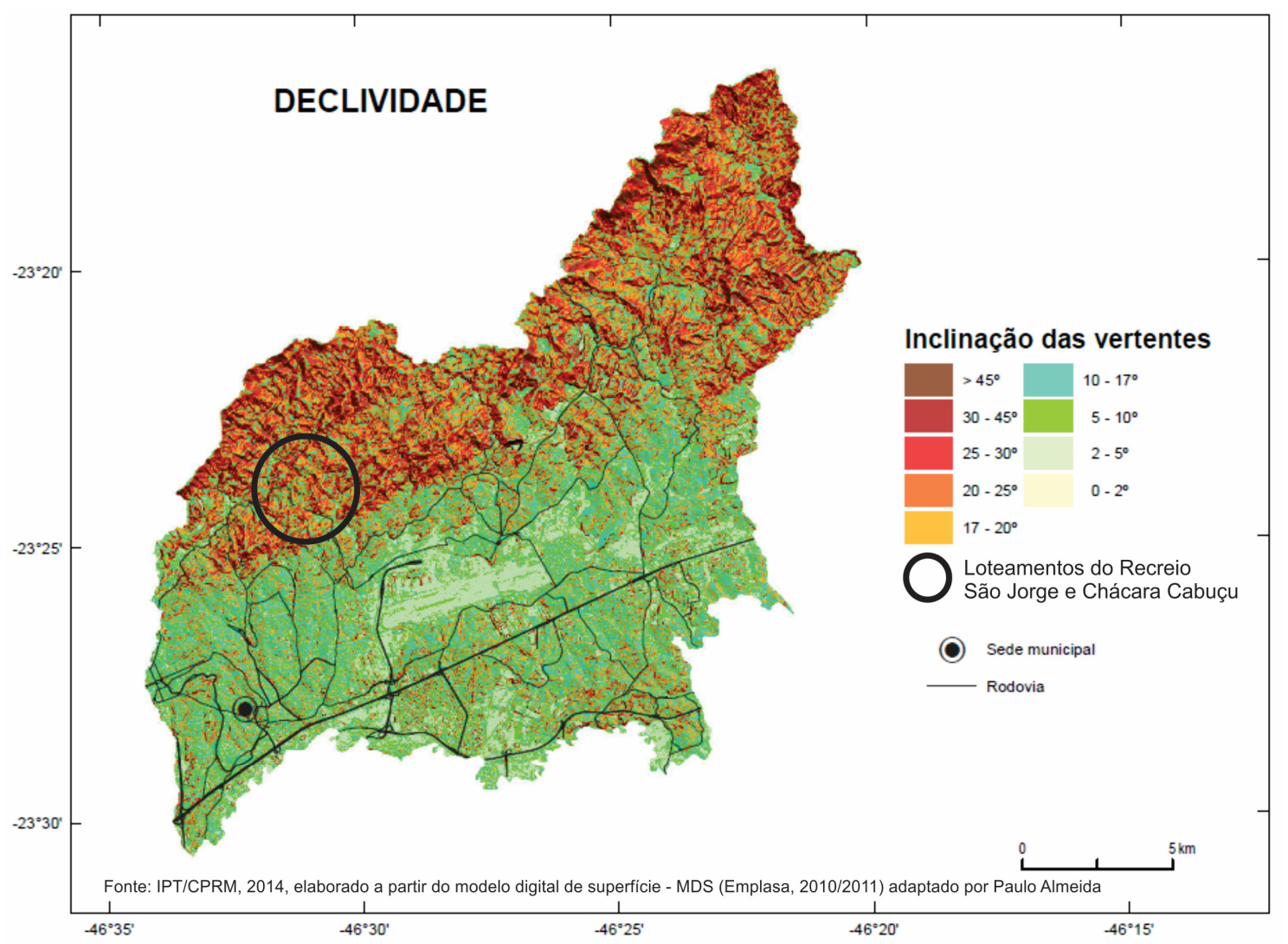

Mapa 15. Declividade do Município de Guarulhos

Conforme salienta Andrade (2009, pg. 85):

Pode-se concluir que, no Planalto Atlântico predomina uma paisagem composta por morros e pequenos maciços montanhosos, acidentados e irregulares, que representam verdadeiros obstáculos para a localização das aglomerações urbanas. 
Contudo, mesmo que representem "verdadeiros obstáculos" para a ocupação humana, as pessoas ainda assim ocupam estes terrenos devido a inúmeros fatores, o que torna imprescindível a ação do poder público através do planejamento urbano e ambiental e do disciplinamento do uso e ocupação do território.

\section{Planejamento Ambiental e Urbano e a Legislação Municipal de Guarulhos}

\section{O Plano Diretor de Guarulhos}

Como já foi observado anteriormente, dentro das determinações do Art. 182 da Constituição Federal (BRASIL, 1988) e do Estatuto da Cidade (BRASIL, 2001), foram estabelecidas as regras e obrigações para a elaboração do Plano Diretor para todos os municípios que se enquadrassem nas condições estabelecidas pela Lei Federal $n^{\circ}$ 10.257/2001. O Plano Diretor, como já foi abordado neste trabalho, serve como instrumento de aplicação das normas de uso e ocupação do solo, estabelecendo as possibilidades de uso de cada área do território municipal. É através do Plano Diretor que o poder público estabelece o planejamento ambiental e urbano de seu território.

Para se enquadrar dentro da legislação vigente e também como forma de organizar a apropriação do território, a Prefeitura Municipal de Guarulhos publicou a Lei $N^{\circ}$ 6.055, DE 30 DE DEZEMBRO DE 2004 que em seu artigo $1^{\circ}$,

[...] aprova o Plano Diretor do Município de Guarulhos nele estabelecendo as diretrizes e normas para o seu desenvolvimento, orientando os agentes públicos e privados que atuam na construção e gestão da cidade, com o propósito de melhorar a qualidade de vida de seus moradores e usuários, promover o progresso urbano, econômico e social para todos, pautando-se pelos princípios, normas e instrumentos da Constituição Federal, da Constituição Estadual, do Estatuto das Cidades e da Lei Orgânica do Município. (PMG, 2004, pg. 1).

No que diz respeito ao planejamento ambiental e urbano ou a regularização de áreas em risco de movimentos gravitacionais de massa e enchentes, o Plano Diretor é bastante vago, tratando destes temas de forma fragmentada ao longo de seus artigos.

O Plano Diretor do Município de Guarulhos, em seu artigo $1^{\circ}$ estabelece alguns eixos estratégicos para o seu embasamento, dentre eles, o $2^{\circ}$ eixo define como prioridade a garantia das funções sociais da cidade aos seus habitantes, de forma a proporcionar qualidade urbana, ambiental e social em todas as regiões e locais de 
moradia. $\mathrm{O} 4^{\circ}$ eixo estratégico também coloca como prioridade a preservação e recuperação do meio ambiente. (PMG, 2004)

Os artigos $3^{\circ}$ e $4^{\circ}$, do "TÍTULO II - DAS DIRETRIZES GERAIS DA POLÍTICA URBANA - CAPÍTULO I - DA FUNÇÃO SOCIAL DA CIDADE E DA PROPRIEDADE" estabelecem em alguns de seus pontos que, para que a cidade e a propriedade cumpram suas funções sociais, estas têm como prioridade a promoção da moradia adequada $^{3}$, de serviços públicos como fornecimento de água e eletricidade, coleta de esgoto, devendo respeitar os limites urbanísticos estabelecidos pela legislação, garantindo o uso e ocupação compatíveis com a melhoria do meio ambiente, principalmente dos mananciais, cursos d'água, áreas arborizadas, reservas florestais, etc. (PMG, 2004).

O Art. $7^{\circ}$ do "Capítulo II - DOS OBJETIVOS GERAIS DA POLÍTICA URBANA" coloca como objetivos:

I - prover a alocação adequada de infra-estrutura urbana, espaços, equipamentos e serviços públicos em todas as regiões da cidade, para os habitantes e para as atividades econômicas em geral, respeitando as áreas de preservação ambiental ou rural permitindo um meio ambiente adequado;

II - propiciar a recuperação e melhoria das condições de moradia, implementando-se as medidas necessárias para a regularização urbanística, administrativa e fundiária;

III - apresentar programas de reabilitação ou de remoção de cidadãos residentes em áreas precárias e de risco para áreas adequadas, objetivando viabilizar habitação de interesse social nas áreas passíveis de uso e que estejam ociosas;

IV - preservar, recuperar e aproveitar adequadamente:

a) o meio ambiente natural e construído;

b) o patrimônio cultural, histórico, artístico e paisagístico;

c) as áreas de interesse ambiental, localizadas no perímetro de proteção aos mananciais.

$\mathrm{V}$ - criar áreas especiais sujeitas a regimes urbanísticos específicos; (PMG, 2004, pg. 2).

Ao analisarmos os incisos acima, podemos compreender que a infraestrutura urbana deve ser universalizada, respeitando as áreas de preservação ambiental e permitindo a melhoria das condições de moradia através de medidas necessárias à

\footnotetext{
${ }^{3}$ Entende-se por moradia adequada, aquela que possua construção sólida e arejada, redes de água, esgoto, instalações sanitárias, drenagem, energia elétrica, iluminação pública, coleta de lixo, ruas pavimentadas, serviço de transporte coletivo e acesso aos equipamentos sociais básicos de educação, saúde, segurança, cultura, lazer, comércio e serviços locais (PMG, 2004, p. 15).
} 
sua regulamentação, seja através de programas de reabilitação ou remoção dos residentes de áreas precárias e de risco para áreas adequadas à habitação. 0 aproveitamento, recuperação e preservação devem abarcar as áreas naturais ou construídas, bem como o patrimônio cultural, histórico e paisagístico e as áreas de proteção aos mananciais. (PMG, 2004).

Além disso, o Artigo $8^{\circ}$ determina que, para o cumprimento da função social da cidade, além do Plano Diretor, são necessários instrumentos de planejamento, tais como o zoneamento municipal, a legislação de parcelamento, uso e ocupação do solo e programas e projetos especiais de urbanização. Dessa maneira, o artigo 10, em seu inciso II, determina a possibilidade de desapropriação por interesse social, necessidade ou utilidade pública (PMG, 2004), o que permite interpretar, portanto, a possibilidade de desapropriação de residências, caso estas estejam em áreas de risco de desastre ambiental.

Contudo, o artigo 12, do "TíTULO III - DO ZONEAMENTO, USO E OCUPAÇÃO DO SOLO - CAPÍTULO I - DAS DIRETRIZES GERAIS" determina que a ordenação e uso do solo devem "buscar a preservação de áreas urbanizadas e não urbanizadas, evitando a especulação imobiliária, bem como a ocorrência de desastres naturais e prejuízos à qualidade de vida" (PMG, 2004, pg. 4). Isto significa que um dos pontos do Plano Diretor é a ordenação, ou seja, o disciplinamento do uso do solo de maneira a evitar a ocorrência de desastres naturais. Embora o termo "desastres naturais" seja vago, os incisos II e III do artigo 13 estabelecem que o macrozoneamento e o zoneamento (PMG, 2004, pg. 4) devem:

[...] designar as unidades de conservação ambiental, paisagística e cultural e outras áreas protegidas por lei, distinguindo as de preservação permanentes das temporárias e suas condições de uso; [...] estabelecer restrição à utilização de áreas de riscos geológicos ${ }^{4}$.

Dessa maneira, o artigo 14 determina que, para a realização de atividades que modifiquem o meio ambiente, é necessária a realização de Estudo de Impacto Ambiental - EIA; Relatório de Impacto Ambiental - RIMA; e Estudo Prévio de Impacto de Vizinhança - EPIV. (PMG, 2004).

\footnotetext{
${ }^{4} \mathrm{O}$ risco geológico pode ser definido como a "probabilidade de um acontecimento perigoso, associado aos fenômenos geológicos que fazem parte do funcionamento normal do planeta Terra, ocorrer numa determinada área num dado momento. Este tipo de risco natural pode ter impacto negativo na sociedade, causando danos humanos e/ou materiais. (PORTO EDITORA, 2015). Abalos sísmicos, erupções vulcânicas, inundações e deslizamentos de terreno são exemplos de riscos geológicos.
} 
Disposições Gerais sobre o Macrozoneamento

O Capítulo II, na Sessão do Macrozoneamento, determina que o território do município seja dividido segundo alguns critérios, dentre os quais estão o tipo de cobertura vegetal e o uso do solo urbano ou rural e tem como um de seus objetivos a "contenção do avanço da área urbana em áreas que venham prejudicar a qualidade ambiental da cidade" (PMG, 2004, pg. 4).

Dentre as macrozonas estabelecidas pelo Plano Diretor, podemos dar destaque à Macrozona de Uso Rural-Urbano e à Macrozona de Proteção Ambiental. No caso da Macrozona de uso Rural-urbano, podemos destacar como objetivos da legislação a preservação das atividades agrícolas, mineradoras e turísticas compatíveis com a preservação ambiental e com o uso residencial, qualificando os assentamentos habitacionais já existentes na área com uma rede de infraestrutura urbana. No caso da Macrozona de Proteção Ambiental, os principais objetivos da legislação (PMG, 2004, pg. 5) são:

I - preservar os recursos naturais e a biodiversidade;

II - fomentar as atividades de pesquisas, ecoturismo e educação ambiental;

III - proteger e recuperar a vegetação nativa e dos mananciais;

IV - garantir a presença do verde e de espaços vazios na construção da paisagem;

V - possibilitar atividades rurais compatíveis com a proteção ambiental.

Podemos notar que na Macrozona de Proteção Ambiental, a ocupação residencial é praticamente vedada, sendo restrita às atividades rurais, visto que os principais objetivos se referem à ocupação do território pelos sistemas naturais nativos, através de sua proteção e recuperação, sendo que, segundo o artigo 43 , o parcelamento do solo urbano na Macrozona de Proteção Ambiental "deverá atender as legislações específicas federais, estaduais e municipais" (PMG, 2004, p. 8).

Disposições Gerais sobre as Zonas Especiais

O capítulo III determina a criação das Zonas Especiais, que consistem em áreas de tratamento diferenciado das disposições contidas nos parâmetros reguladores de uso e ocupação do solo, sendo necessária a criação de leis específicas para seu uso e ocupação. Estão contidas nessa categoria as Zonas Especiais de Interesse Social - ZEIS; as Zonas de Preservação do Patrimônio - ZPP; e as Zonas 
de Proteção Ambiental - ZPA, sendo que novas Zonas Especiais podem ser criadas de acordo com a necessidade de classificação e planejamento.

As ZEIS são entendidas como áreas de assentamentos habitacionais de população de baixa renda que já existam e estejam consolidados, mas que necessitam de regularização urbanística e fundiária ou de áreas livres que permitam a implantação de programas habitacionais de interesse social. No âmbito das ZEIS, o Plano Diretor destaca quatro categorias (PMG, 2004, p. 6):

I - ZEIS-A: assentamentos habitacionais consolidados, surgidos espontaneamente e ocupados sem título de propriedade por população de baixa renda, carentes de infra-estrutura urbana;

II - ZEIS-L: áreas de loteamentos irregulares ou clandestinos consolidados;

III - ZEIS-G: áreas livres ou glebas de terra não utilizadas, não edificadas ou subutilizadas, adequadas à implantação de programas habitacionais de interesse social.

Como é possível observar, essas categorias não fazem referência direta a loteamentos irregulares em áreas suscetíveis a movimentos gravitacionais de massa ou de risco geológico, conforme termo utilizado pelo documento. De qualquer maneira, a área objeto deste estudo foi classificada como ZEIS-L $n^{\circ} 6$, exigindo redação de lei própria para a fixação de regras de uso e ocupação do solo.

As ZPAS são definidas como áreas públicas ou particulares onde pode haver interesse ambiental, paisagístico ou recreativo que demandem a preservação do meio ambiente, que minimizem os impactos causados pela urbanização, sendo que o Município através de suas atribuições, poderá instituir unidade de conservação, mecanismos ou incentivos para o uso e ocupação do solo com a finalidade de preservar ou recuperar as condições ambientais adequadas (PMG, 2004).

O artigo 38 também estabelece que a incorporação de novas áreas ao perímetro urbano fica condicionada a estudos que demonstrem a impossibilidade de expansão dentro do perímetro atual e que considerem "os impactos da expansão urbana sobre o sistema de drenagem natural das águas e o meio ambiente adequado" (PMG, 2004 p. 7).

\section{Meio Ambiente e Planejamento Ambiental}

O planejamento ambiental tem um destaque especial nos artigos 53 e 54 , do “TíTULO V - DO MEIO AMBIENTE - CAPÍTULO I - DAS DIRETRIZES GERAIS", os quais determinam que para o cumprimento da função social da cidade e da 
propriedade é preciso que todos usem adequadamente, preservem e recuperem: o meio ambiente, com destaque para a vegetação, os mananciais (superficiais e subterrâneos), os cursos e reservatórios de água, o relevo, o solo, a paisagem, etc., atuando o Poder Público Municipal em conjunto com os demais poderes institucionais, com a iniciativa privada e com a sociedade civil para o alcance dos seguintes objetivos (PMG, 2004, p. 10):

I - preservar e permitir por meio de ações, que se renovem os mananciais superficiais e subterrâneos, cursos e reservatórios superficiais ou subterrâneos de água, regulamentando o uso racional e adequado das águas;

II - universalizar o acesso à água potável e ao esgotamento sanitário, ao mesmo tempo em que se desenvolvem medidas públicas e privadas para o tratamento e disposição final das águas servidas;

III - complementar ou recuperar o sistema de drenagem das águas nas áreas urbanizadas, de modo a minimizar a formação e agravamento de áreas inundáveis e de escorregamento;

IV - evitar as mudanças nocivas ao relevo, preservar a vegetação, o solo e a harmonia natural, conter os riscos de escorregamento;

$\mathrm{V}$ - implantar áreas verdes de forma equilibrada e homogênea nas diversas regiões da cidade, incentivando o seu uso para o lazer;

VI - recuperar e manter a estética urbana em geral, os passeios e logradouros públicos;

VII - eliminar os depósitos clandestinos de lixo, entulho, lodo e terra contaminada, facilitando alternativas de deposição adequada, incentivando a coleta seletiva, a reciclagem e a redução do volume depositado;

VIII - elaborar, aprovar e implantar Programa de Fiscalização Ambiental Preventiva e outros instrumentos legais referentes ao Meio Ambiente;

IX - promover a educação ambiental, aprimorar a legislação, intensificar as ações de controle e a fiscalização;

$X$ - O Poder Executivo, a partir desta lei, será responsabilizado quando permitir a ocupação ou não promover a desocupação de invasões em áreas públicas municipais destinadas a lazer e nas de uso institucional.

Ao analisarmos os incisos acima citados, principalmente os incisos IV e V, podemos notar que há o compromisso de parceria entre todas as esferas do poder público, iniciativa privada e sociedade civil em evitar transformações do relevo que venham formar ou agravar áreas sujeitas a enchentes e a movimentos gravitacionais de massa, bem como a preservação da vegetação e do solo com o intuito de conter os risco de escorregamentos.

O artigo 58 ainda determina que todas as esferas do poder público elaborem, com participação da sociedade civil, o Plano Diretor do Manejo de Águas Pluviais, tendo a "bacia hidrográfica como unidade básica de planejamento e gestão dos 
recursos hídricos, dos aspectos ambientais e do desenvolvimento urbano" (PMG, 2004 , p. 11) e que tenha como um de seus objetivos o combate a enchentes e a erosão.

Além disso, os artigos 118 e 119 estabelecem a criação do Sistema Municipal de Gestão do Planejamento, tendo como objetivos principais a articulação das políticas e investimentos públicos, bem como a elaboração e o desenvolvimento de planos e programas, além da análise e revisão das diretrizes estabelecidas na Lei Orgânica Municipal, no Plano Diretor e nas demais leis vigentes.

\section{Lei de Uso e Ocupação do Solo do Município de Guarulhos}

No ano de 2007 foi aprovada a Lei Municipal 6.253, que dispõe sobre o Uso, a Ocupação e o Parcelamento do Solo no Município de Guarulhos. Na prática, esta lei determina o zoneamento de uso e ocupação do solo, já previsto pelo Plano Diretor e define com maior detalhamento a aptidão de cada parcela do município. Sua publicação permite vislumbrar de que maneira as regras aplicadas pelo plano diretor podem alterar as formas de ocupação do território e de qual maneira essa ocupação será disciplinada, planejada ou remediada, permitindo uma melhor análise da sua aplicabilidade e validade.

Nesta lei, a região onde se localiza a microbacia da Taquara do Reino, bem como o loteamento do Recreio São Jorge, recebe uma classificação mais objetiva quanto aos seus usos e restrições, assim como também foram definidos mais detalhadamente os problemas ambientais encontrados nessa área.

Dessa maneira, o artigo 35 adiciona algumas normas para ocupação das áreas classificadas como ZEIS-L, estabelecendo que para cada ZEIS deva ser feita audiência pública para a elaboração de um Plano de Urbanização específico, através de lei específica, prevendo no mínimo:

I - a composição do Conselho Gestor;

II - diretrizes, índices e parâmetros para o parcelamento, uso e ocupação do solo, e a previsão de instalação de infra-estrutura;

III - condições para o remembramento ou desdobro de lotes;

IV - projetos e intervenções urbanísticas necessárias;

$V$ - previsão de equipamentos e áreas públicas que poderão situar-se em perímetro próximo ao das ZEIS; VI - instrumentos aplicáveis para regularização fundiária e jurídica;

VII - a forma de participação da sociedade na implementação dos planos; 
VIII - as obrigações atribuídas ao responsável pelo empreendimento na medida de sua culpabilidade, diferenciando-se os empreendimentos irregulares dos clandestinos.

$\S 1^{\circ}$ Deverão ser atendidos os parâmetros estabelecidos em legislação específica para implantação de habitações ou conjuntos de interesse social.

$\S 2^{\circ}$ Deverá ser criado um Conselho Gestor para cada Zona Especial de Interesse Social, que terá composição paritária entre os membros do Executivo e da sociedade civil, garantindo-se a presença de associação representante de moradores da área, quando houver, e terá por incumbência o acompanhamento e a fiscalização da implementação do Plano de Urbanização.

$\S 3^{\circ} \mathrm{O}$ Plano de Urbanização poderá incluir mais de uma ZEIS, caso haja necessidade.

O artigo 36 da mesma lei ainda determina que nos casos em que a ZEIS se sobreponha a outras zonas, tais como ZPA, ZEPAM, ZPDS e ZPE-APA, seu Plano de Urbanização deve seguir diretrizes tais como:

I - promover o desenvolvimento urbano dos assentamentos existentes, sem expansão, subordinado à recuperação e preservação do meio ambiente natural;

II - considerar os condicionantes físico-territoriais, em particular os aspectos morfológicos e hidrográficos;

III - estabelecer índices de ocupação e usos compatíveis com a recuperação e conservação do meio ambiente natural;

IV - propor alternativas habitacionais multifamiliares que permitam adensamento sem expansão do tecido urbano.

Além da já citada classificação como ZEIS-L, a área objeto de estudo deste trabalho também recebeu a classificação de Zona de Proteção e Desenvolvimento Sustentável - ZPDS-2 - sendo entendida como:

[...] porções do território destinadas à conservação da natureza e à implantação de atividades econômicas compatíveis com a proteção dos ecossistemas locais, integrando seu perímetro as áreas situadas na Macrozona de Uso Rural Urbano, exceto aquelas já ocupadas por assentamentos habitacionais, bem como, aquelas ocupadas por áreas de extração mineral e deposição de resíduos sólidos (PMG, 2007).

Como ZPDS-2, sua classificação corresponde "às áreas compostas por morros altos, com declividade superior a $45 \%$ (quarenta e cinco por cento), muito restritas a ocupação" (PMG, 2007). Contudo, a lei deixa uma brecha não muito clara ao citar que se aplica a todas as áreas do município: "exceto aquelas já ocupadas por assentamentos habitacionais". Esta expressão torna a interpretação da lei bastante flexível no que diz respeito às habitações irregulares existentes nestas áreas, podendo torná-la completamente nula ou, ao cabo, restrita apenas a novas construções. 
Entretanto, o artigo $6^{\circ}$ desta lei é bem claro ao determinar as condições para ocupação e parcelamento do solo no município, que está proibido nos terrenos:

I - alagadiços ou sujeitos a inundação, antes de serem tomadas as providências necessárias a assegurar o escoamento das águas; II - considerados contaminados por materiais nocivos ao meio ambiente e à saúde pública ou naqueles em que a poluição impeça a existência de condições sanitárias adequadas, até a correção do problema;

III - com declividade superior a 30\% (trinta por cento), salvo se atendidas as exigências específicas das autoridades competentes, observando-se o limite máximo de $45 \%$ (quarenta e cinco por cento); IV - onde as condições geológicas não aconselhem a edificação; $\mathrm{V}$ - em áreas de preservação ecológica.

$\S 1^{\circ}$ Nas glebas contíguas a mananciais, cursos d'água, represas e demais recursos hídricos ou com vegetação arbórea, conforme definido na legislação municipal específica ou inseridas em Zonas de Preservação ou Proteção Ambiental - ZPA, ZEPAM e ZPDS, o parcelamento do solo não será permitido, a não ser com a manifestação autorizativa clara e inequívoca dos órgãos competentes definidos em legislação pertinente.

$\S 2^{\circ}$ No caso de parcelamento de glebas com declividade entre $30 \%$ (trinta por cento) e $45 \%$ (quarenta e cinco por cento), o projeto respectivo deverá ser acompanhado de declaração do responsável técnico de que é viável e seguro edificar-se no local e deverá atender, se for o caso, as exigências do órgão municipal competente.

$\S 3^{\circ}$ Nas áreas referidas no inciso IV deste artigo deverá ser apresentado laudo geotécnico elaborado por profissional habilitado, demonstrando a viabilidade da execução do parcelamento.

$\S 4^{\circ} \mathrm{A}$ declaração e o laudo técnico a que se referem os parágrafos anteriores devem estar acompanhados da respectiva Anotação de Responsabilidade Técnica - ART do Conselho Regional de Engenharia, Arquitetura e Agronomia - CREA.

A lei de zoneamento ainda estabelece que o parcelamento de solo nesta área deve estabelecer lotes de, no mínimo, $4.000 \mathrm{~m}^{2}$ para apenas uma unidade habitacional, desde que obedecidas todas as regras dispostas na lei, conforme anexo 1.

\section{Lei De Criação Da Área De Proteção Ambiental Cabuçu - Tanque Grande}

No ano de 2010 foi aprovada a Lei Municipal 6.798, que cria a Área De Proteção Ambiental Cabuçu - Tanque Grande, que segundo a Lei Federal 9.985 e através do SNUC, é entendida como uma:

[...] área em geral extensa com um certo grau de ocupação humana, dotada de atributos abióticos, bióticos, estéticos ou culturais especialmente importantes para a qualidade de vida e o bem-estar das populações humanas e tem como objetivos básicos proteger a 
diversidade biológica, disciplinar o processo de ocupação e assegurar a sustentabilidade do uso dos recursos naturais (PMG, 2010).

A lei tem como principais diretrizes a promoção do desenvolvimento aliado à conservação dos recursos ambientais desde que consoante com atividades de geração de renda que permitam a sustentabilidade, a proteção aos mananciais, a recuperação de áreas degradadas e a requalificação de áreas urbanizadas já existentes de modo a prevenir e reduzir as áreas de risco dentre outras.

Além das regras de estabelecimento da área de proteção ambiental, a Lei Municipal 6.798 também estabeleceu regras de zoneamento, uso e ocupação das áreas já ocupadas dentro da APA, criando novas restrições e normatizações que se somaram as já estabelecidas pelo Plano Diretor e pela Lei de Uso e Ocupação do Solo.

No caso da área de estudo, além dos zoneamentos como MUR-U, ZEIS-L e ZPDS, o loteamento do Recreio São Jorge também foi classificado como Zona de Uso Sustentável e Recuperação Ambiental - ZUSRA - entendida como as áreas que necessitam requalificar sua ocupação através da regularização urbanística e fundiária das áreas já construídas e consolidadas, "mediante planos de regularização fundiária sustentáveis que permitam a manutenção e recuperação dos componentes ambientais da área, garantindo uma melhoria da qualidade de vida da população local" (PMG, 2010).

A lei ainda determina que a ZUSRA pode se sobrepor a áreas já classificadas como ZEIS e que deve ainda obedecer aos objetivos e diretrizes da APA CabuçuTanque Grande, tais como a necessidade de licenciamento pela Secretaria do Meio Ambiente e demais órgãos competentes quando a obra envolver:

- cortes de mais de 3,00 metros em relação à superfície já existente e aos terrenos vizinhos;

- áreas de declividade superior a 30\% dentro do empreendimento;

- áreas que apresentem processos erosivos; 
- obras de aterro ou barramento que alterem significativamente o escoamento das águas nos fundos de vale caracterizados como margens de curso d'água com até $5 \%$ de declividade.

\section{Plano Municipal de Redução de Riscos e as ações municipais}

Além dos estudos realizados pelos diversos órgãos municipais, a Prefeitura de Guarulhos encomendou um levantamento geotécnico realizado por uma consultoria ambiental para a elaboração do Plano Municipal de Redução de Riscos - PMRR iniciado no ano de 2004, com o objetivo de estabelecer referenciais técnicos e gerenciais que possibilitassem ao poder público a implementação de ações para reduzir e controlar situações de risco de escorregamentos e solapamentos de margens de córregos que representassem ameaça à segurança dos moradores (ROSA E BINDONE, 2004).

Como metodologia, o PMRR foi estabelecido a partir dos seguintes critérios:

a. Mapeamento de riscos;

b. Estimativa de custos para redução de riscos;

c. Plano Diretor Municipal e as ações previstas de desenvolvimento urbano e da política municipal de habitação;

d. Critérios para priorização das intervenções;

Durante dois meses foram realizadas vistorias em levantamento expedito, através de investigações geológico-geotécnicas de superfície, baseadas na análise de dados técnicos já disponíveis, em 55 áreas de favelas e loteamentos precários onde havia moradias em situação de risco de acidentes ou que registraram ocorrências de escorregamento de encostas e solapamento de margem de córregos. Como resultado, foram identificadas 46 áreas com este tipo de situação.

No caso específico do loteamento do Recreio São Jorge e Novo Recreio, foram indicadas áreas com "Grau de probabilidade" R3 e R4, conforme os parâmetros da tabela abaixo:

Tabela 3 - Critérios para definição do grau de probabilidade de ocorrência de processos de instabilização do tipo escorregamentos em encostas ocupadas e solapamento de margens de córregos. Fonte: PMRR Guarulhos, 2004.

\begin{tabular}{|c|l|}
\hline $\begin{array}{c}\text { Grau de } \\
\text { probabilidade }\end{array}$ & \multicolumn{1}{c|}{ Descrição } \\
\hline & $\begin{array}{l}\text { Os condicionantes geológico-geotécnicos predisponentes (declividade, tipo de terreno, etc.) e } \\
\text { o nível de intervenção no setor são de baixa potencialidade para o desenvolvimento de } \\
\text { processos de escorregamentos e solapamentos. }\end{array}$ \\
\hline
\end{tabular}




\begin{tabular}{|l|l|}
\hline $\mathbf{R} 1$ \\
Baixo & $\begin{array}{l}\text { Não há indícios de desenvolvimento de processos de instabilização de encostas e de margens } \\
\text { de drenagens. } \\
\text { É a condição menos crítica. } \\
\text { Mantidas as condições existentes, não se espera a ocorrência de eventos destrutivos no } \\
\text { período de um ciclo chuvoso. }\end{array}$ \\
\hline $\begin{array}{l}\text { Os condicionantes geológico-geotécnicos predisponentes (declividade, tipo de terreno, etc.) e } \\
\text { O nível de intervenção no setor são de baixa potencialidade para o desenvolvimento de } \\
\text { processos de escorregamentos e solapamentos. } \\
\text { Observa-se a presença de alguma(s) evidência(s) de instabilidade (encostas e margens de } \\
\text { drenagens) porém incipiente(s). } \\
\text { Mantidas as condições existentes, é reduzida a possibilidade de ocorrência de eventos } \\
\text { destrutivos durante episódios de chuvas intensas e prolongadas, no período de um ciclo } \\
\text { chuvoso. }\end{array}$ \\
\hline $\begin{array}{l}\text { Os3 condicionantes geológico-geotécnicos predisponentes (declividade, tipo de terreno, etc.) e } \\
\text { Alto nivel de intervenção no setor são de alta potencialidade para o desenvolvimento de } \\
\text { processos de escorregamentos e solapamentos. } \\
\text { Observa-se a presença de significativa(s) evidência(s) de instabilidade (trincas no solo, } \\
\text { degraus de abatimento em taludes, etc.) } \\
\text { Mantidas as condições existentes, é perfeitamente possível a ocorrência de eventos } \\
\text { destrutivos durante episódios de chuvas intensas e prolongadas, no período de um ciclo } \\
\text { chuvoso. }\end{array}$ \\
$\begin{array}{l}\text { Os condicionantes geológico-geotécnicos predisponentes (declividade, tipo de terreno, etc.) e } \\
\text { o nível de intervenção no setor são de alta potencialidade para o desenvolvimento de } \\
\text { processos de escorregamentos e solapamentos. } \\
\text { As evidências de instabilidade (trincas no solo, degraus de abatimento em taludes, trincas em } \\
\text { moradias ou em muros de contenção, árvores ou postes inclinados, cicatrizes de } \\
\text { escorregamento, feições erosivas, proximidade da moradia em relação ao córrego, etc. ) são } \\
\text { expressivas e estão presentes em grande número e/ou magnitude. } \\
\text { É a condição mais crítica.Mantidas as condições existentes, é muito provável a ocorrência de } \\
\text { eventos destrutivos durante episódios de chuvas intensas e prolongadas, no período de um } \\
\text { ciclo chuvoso. }\end{array}$ \\
\hline
\end{tabular}

Segundo os resultados do PMRR, a região do Recreio São Jorge e Novo Recreio - áreas que ocupam parte da bacia Taquara do Reino - possuíam, no ano de 2004, 598 domicílios em área de risco R3 e R4, sendo classificada como a primeira colocada na lista de prioridade de intervenção do município.

Além da classificação em níveis de risco, o PMRR ainda sugeriu algumas formas de intervenção para as áreas de risco mapeadas, conforme tabela 4:

Tabela 4. Tipos de intervenção para as áreas de risco mapeadas pelo PMRR

\begin{tabular}{|c|l|}
\hline TIPO DE INTERVENÇÃO & \multicolumn{1}{c|}{ DESCRIÇÃO } \\
\hline $\begin{array}{c}\text { SERVIÇOS DE LIMPEZA } \\
\text { E RECUPERAÇÃO }\end{array}$ & $\begin{array}{l}\text { Serviços de limpeza de entulho, lixo, etc. Recuperação e/ou } \\
\text { limpeza de sistemas de drenagem, esgotos e acessos. Também } \\
\text { incluem obras de limpeza de canais de drenagem. Correspondem } \\
\text { a serviços manuais e/ou utilizando maquinário de pequeno porte. }\end{array}$ \\
\hline \multicolumn{2}{|c|}{$\begin{array}{l}\text { Implantação de sistema de drenagem superficial (canaletas, } \\
\text { rápidos, caixas de transição, escadas d'água, etc.). Implantação de } \\
\text { proteção superficial vegetal (gramíneas) em taludes com solo } \\
\text { exposto. Eventual execução de acessos para pedestres (calçadas, } \\
\text { PROTEÇÃO VEGETAL (GRAMÍNEAS) } \\
\text { E DESMdarias, etc.) integrados ao sistema de drenagem. Proteção } \\
\text { vegetal de margens de canais de drenagem. Desmonte de blocos } \\
\text { rochosos e matacões. Predomínio de serviços manuais e/ou com } \\
\text { maquinário de pequeno porte. }\end{array}$} \\
MATACÕES
\end{tabular}




\begin{tabular}{|c|c|}
\hline $\begin{array}{l}\text { OBRAS DE DRENAGEM } \\
\text { DE SUBSUPERFÍCIE }\end{array}$ & $\begin{array}{l}\text { Execução de sistema de drenagem de subsuperfície (trincheiras } \\
\text { drenantes, DHP, poços de rebaixamento, etc.). Correspondem } \\
\text { a serviços parcial ou totalmente mecanizados. }\end{array}$ \\
\hline $\begin{array}{l}\text { ESTRUTURAS DE CONTENÇÃO } \\
\text { LOCALIZADAS OU LINEARES }\end{array}$ & $\begin{array}{l}\text { Implantação de estruturas de contenção localizadas, como } \\
\text { chumbadores, tirantes, microestacas e muros de contenção } \\
\text { passivos de pequeno porte }\left(h_{\max }=5 \mathrm{~m} \text { e } I_{\max }=10 \mathrm{~m}\right) \text {. Obras de } \\
\text { contenção e proteção de margens de canais (gabiões, muros } \\
\text { de concreto, etc.). Correspondem a serviços parcial ou } \\
\text { totalmente mecanizados. }\end{array}$ \\
\hline $\begin{array}{l}\text { OBRAS DE TERRAPLENAGEM } \\
\text { DE MÉDIO A GRANDE PORTE }\end{array}$ & $\begin{array}{l}\text { Execução de serviços de terraplenagem. Execução combinada } \\
\text { de obras de drenagem superficial e proteção vegetal (obras } \\
\text { complementares aos serviços de terraplenagem). Obras de } \\
\text { desvio e canalização de córregos. Predomínio de serviços } \\
\text { mecanizados. }\end{array}$ \\
\hline $\begin{array}{c}\text { ESTRUTURAS DE CONTENÇÃO DE MÉDIO } \\
\text { A GRANDE PORTE }\end{array}$ & $\begin{array}{l}\text { Implantação de estruturas de contenção de médio a grande porte } \\
\text { ( } \mathrm{m}>5 \mathrm{~m} \text { e }>10 \mathrm{~m} \text { ), envolvendo obras de contenção passivas e } \\
\text { ativas (muros de gravidade, cortinas, etc.). Poderão envolver } \\
\text { serviços complementares de terraplenagem. Predomínio de } \\
\text { serviços mecanizados. }\end{array}$ \\
\hline REMOÇÃO DE MORADIAS & $\begin{array}{l}\text { As remoções poderão ser definitivas ou não (para implantação de } \\
\text { uma obra, por exemplo). Priorizar eventuais relocações dentro da } \\
\text { própria área ocupada, em local seguro. }\end{array}$ \\
\hline
\end{tabular}

A partir da publicação do PMRR e das obras necessárias à adequação da ocupação urbana dentro das normatizações previstas na lei, a Prefeitura de Guarulhos publicou o Plano Local de Habitação de Interesse Social - PLHIS, no ano de 2011. De acordo com PLHIS, o Plano Diretor não delimitou as áreas das ZEIS ou encaminhou sua regulamentação para leis específicas como previa e, embora tenha citado que o parcelamento de solo deveria obedecer à legislação federal, estadual e municipal, ao mesmo tempo determinou que se criassem leis específicas que determinassem as diretrizes para este processo, o que em parte foi realizado através da Lei de Zoneamento de 2007, no que diz respeito à ZPDS.

Entretanto, no caso da ZEIS-L do Recreio São Jorge, nenhuma lei específica foi criada até o presente momento devido a esta área estar ainda sob processo de regularização fundiária formalizada por processos já existentes e anteriores à criação das leis de zoneamento, sendo admitido pela própria prefeitura, através do PLHIS, que esta região sofre dificuldades com "a compilação de dados mais aproximados da realidade de ocupação dessas áreas como: quantidade e dimensão dos lotes, número 
de domicílios, infraestrutura instalada, ocupação em área de risco, dentre outros." (PMG, 2011).

Dessa maneira, o estudo delimitou as áreas de intervenção em polígonos, os quais correspondem às áreas oficiais dos bairros. No caso da área de estudo, a bacia Taquara do Reino está inserida no bairro do Cabuçu, sendo esta região denominada de Polígono 18 pelo PLHIS. De acordo com o documento, foram identificados dentro desta área um total de 11.047 lotes, dos quais se estimava a necessidade de remoção de 2.520 edificações. Dos 8.527 lotes restantes, todos precisavam de regularização fundiária.

No que diz respeito às favelas, principalmente pelo fato de a microbacia da Taquara do Reino ter boa parte de sua área ocupada por este tipo de construção, foram anotados o total de sete núcleos, somando 700 domicílios sendo necessária a remoção de 237 unidades habitacionais. Há ainda a necessidade de obras de urbanização complexa em 297 unidades.

Além disso, de acordo com o PLHIS, os vazios do polígono 18 localizados sobre o Recreio São Jorge e Bacia Taquara do Reino estão classificados como "não ocupáveis".

Características geomorfológicas da Microbacia Taquara do Reino.

A área de estudo escolhida localiza-se na microbacia Taquara do Reino, pertencente à bacia do Rio Baquirivu-Guaçu, afluente do rio Tietê, sobre a qual estudos prévios já foram realizados por Andrade (2011), Gomes (2008), Oliveira (2005), Sato (2008), Sato et al (2011) e Uzan (2008). Localizada integralmente dentro da Área de Proteção Ambiental Cabuçu-Tanque Grande, os loteamentos ainda estão totalmente inseridos dentro da Zona de Defesa do núcleo Cabuçu do Parque Estadual da Serra da Cantareira. Esta microbacia abriga os loteamentos Recreio São Jorge e Novo Recreio, que pertencem oficialmente ao bairro do Cabuçu, município de Guarulhos.

A microbacia possui a forma de anfiteatro, entendida por Guerra (2008, pg 44) como "pequeno vale cuja bacia de recepção é sensivelmente alargada na encosta da montanha. O anfiteatro tem, por conseguinte, uma forma semicircular ou oval." No caso da microbacia Taquara do Reino, as linhas de crista estão edificadas e 
pavimentadas, abrigando as principais vias de circulação do loteamento. A drenagem se dá no sentido noroeste-sudeste em direção ao rio Baquirivú-Guaçú.

Como é possível observar no Mapa Hipsométrico (Mapa 16), as altitudes da microbacia estão situadas entre os 760 e 890 metros, sendo mais baixas na direção sudeste e mais altas em todo os eu entorno, por se tratar de uma bacia de drenagem em forma de anfiteatro.

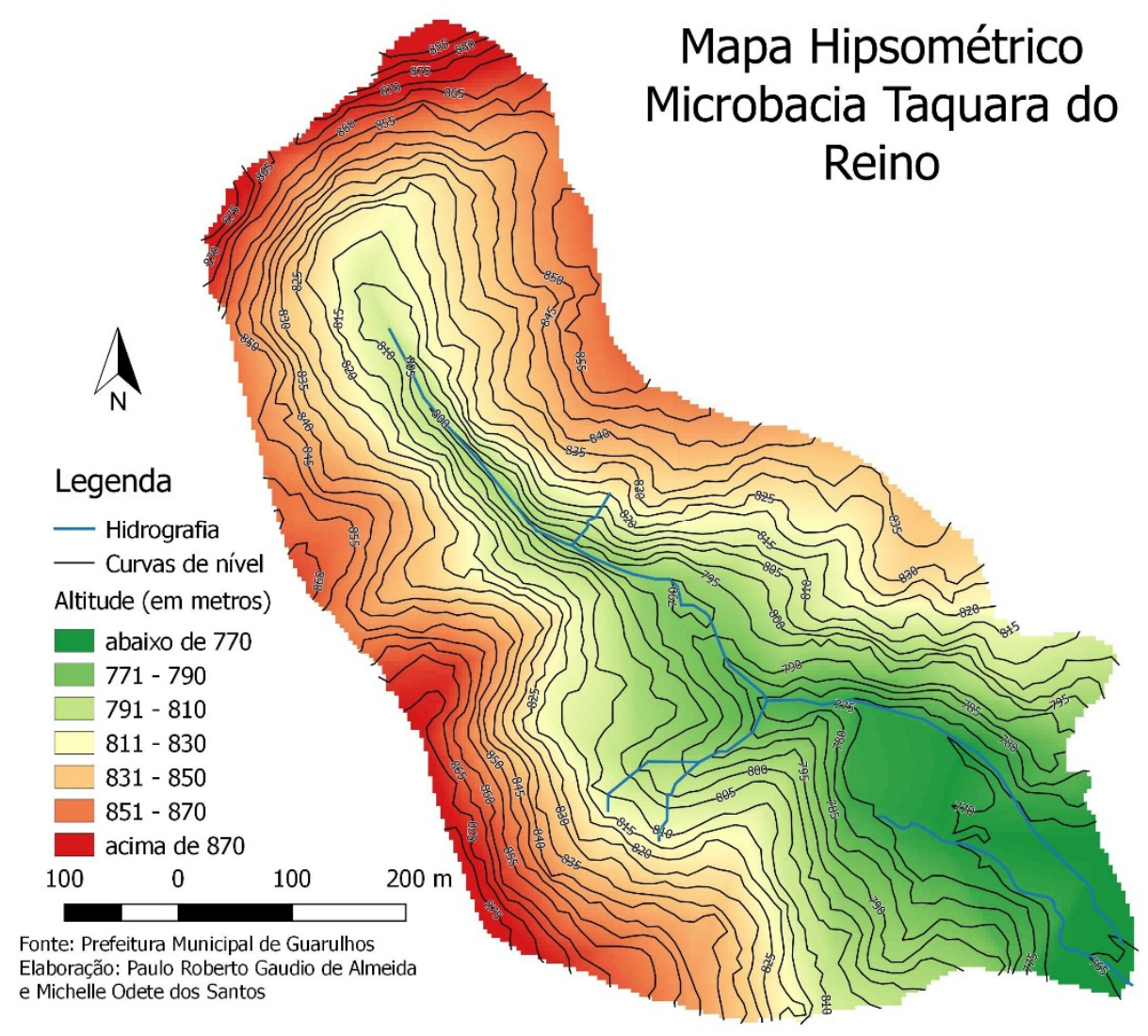

Mapa 16. Mapa Hipsométrico da Microbacia Taquara do Reino

O vale drenado pelo córrego Taquara do Reino é bastante entalhado e profundo, sendo classificado, segundo a matriz dos índices de dissecação do relevo estabelecida por Ross (1991), como uma área de denudação aguçada e grau de entalhamento forte (Da44). Essa configuração de drenagem resultou em vertentes de declividades acentuadas, apresentando a maior parte da área da bacia com declividades classificadas entre forte ondulado (20-45\%) e escarpado (acima de 75\%), segundo a classificação de declividades da Embrapa (1979), conforme mapa clinográfico (Mapa 17) 


\section{Mapa Clinográfico - Microbacia Taquara do Reino}

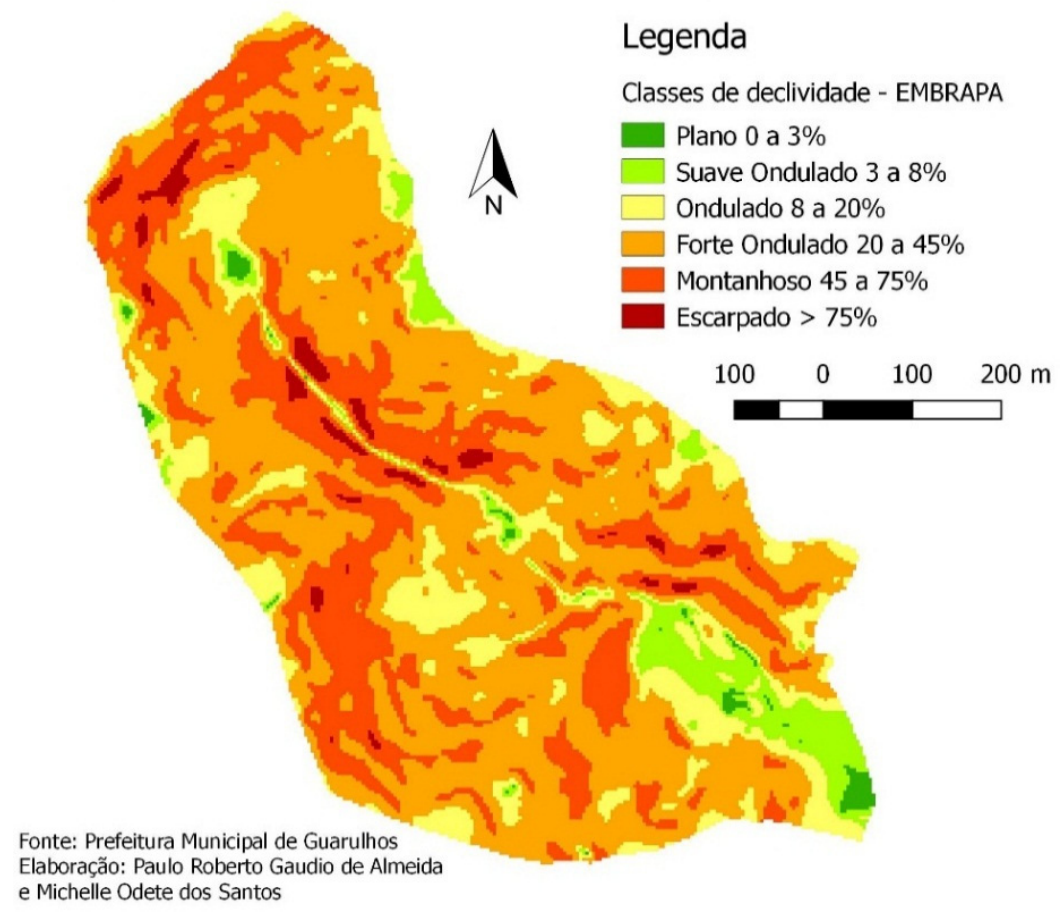

Mapa 17. Mapa Clinográfico Microbacia Taquara do Reino

O mapa de Unidades Geoambientais também demonstra como a maior parte do território da microbacia tem seu relevo classificado em morros baixos e médios abaixo dos 900 metros de altitude

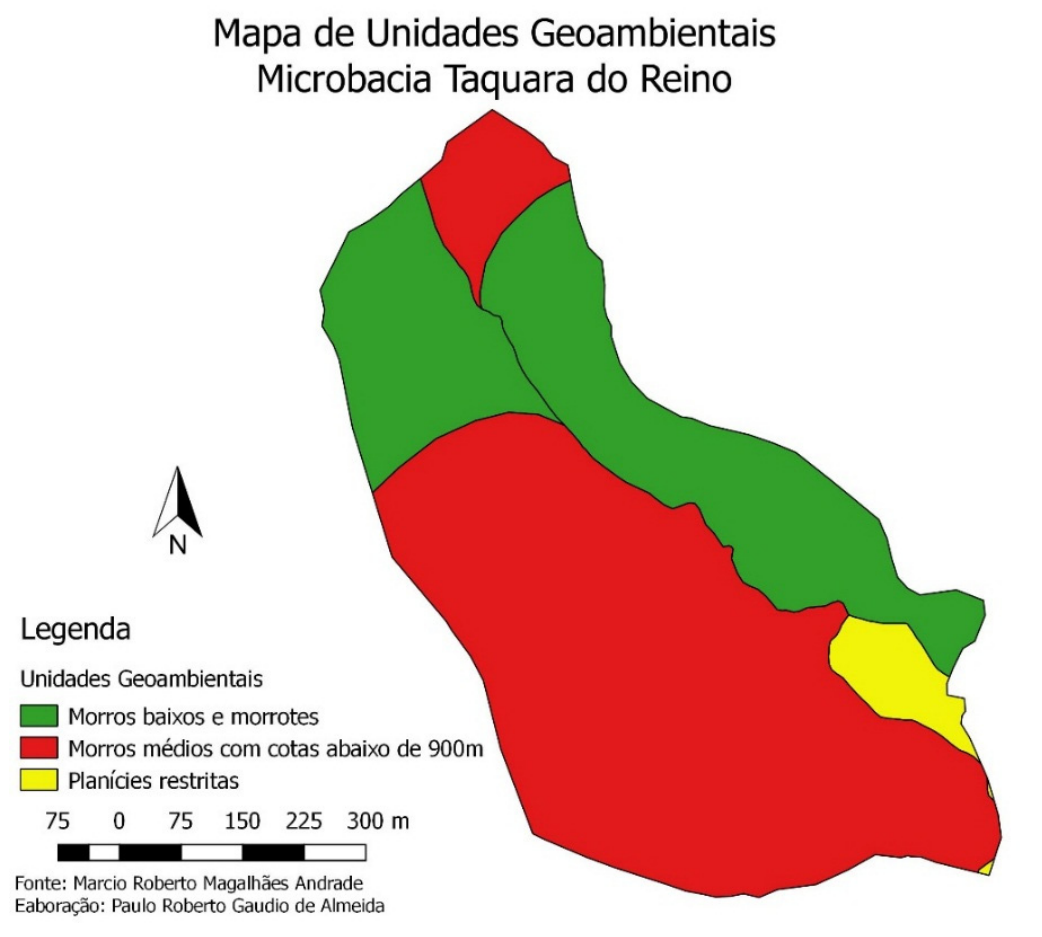

Mapa 18. Mapa de Unidades Geoambientais Microbacia Taquara do Reino 


\section{Características socioeconômicas da microbacia Taquara do Reino}

A microbacia Taquara do Reino está localizada em uma área de 42ha e era originalmente recoberta por vegetação ombrófila de Mata Atlântica. A área abrigava pequenos sítios até meados da década de 1980, porém sua ocupação passou a se intensificar após a realização de loteamentos pela Imobiliária Continental em áreas adjacentes à microbacia no início da década de 1990, conforme demonstra a análise de levantamento aerofotográfico realizada por Sato et al (2011):

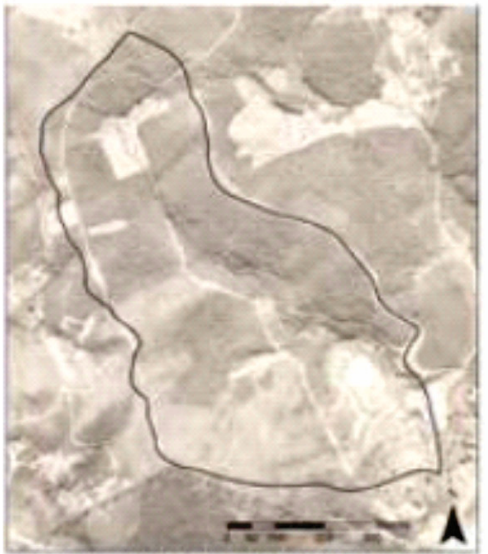

Foto aérea de 1970 (levantamento 1:20.000 - Emplasa)

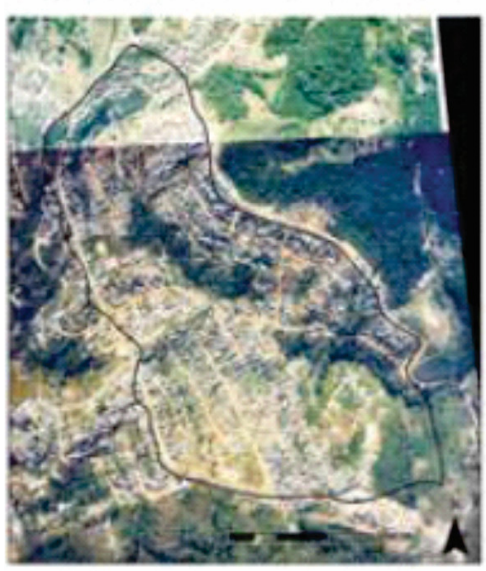

Foto aérea de 2000 (levantamento 1:5.000 - PMG)
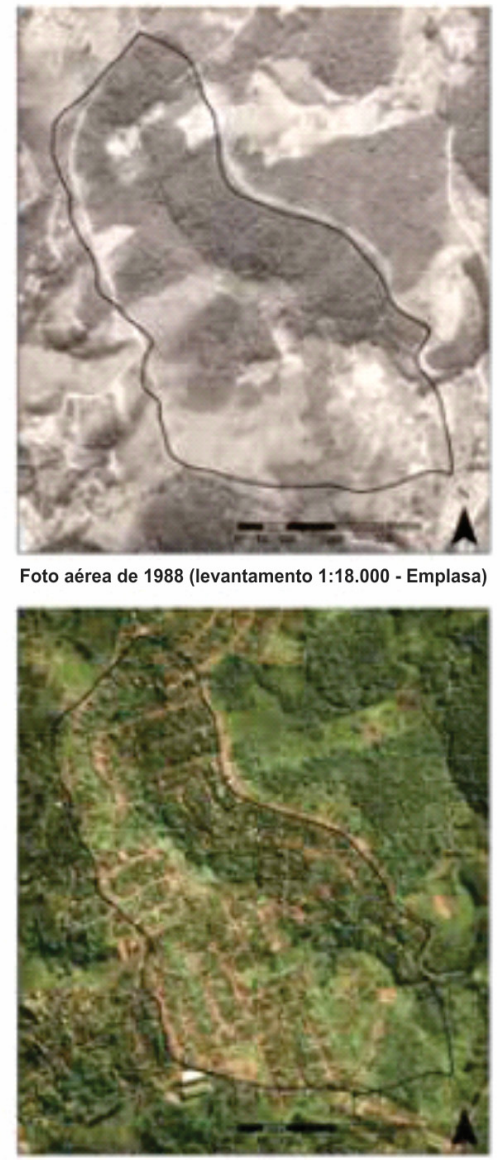

Imagem de Satélite Quickbird de 2004

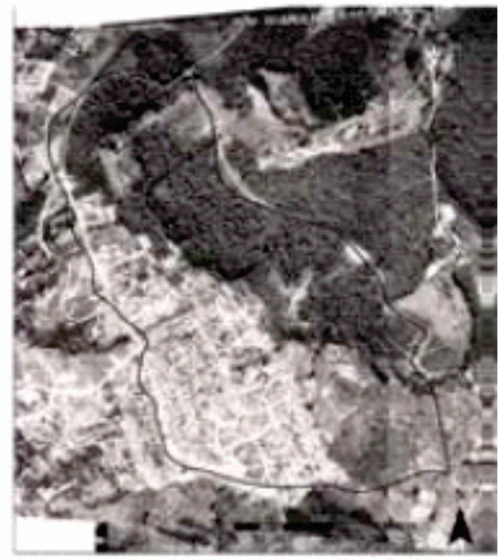

Foto aérea de 1993 (levantamento 1:1.000 - AEROSUL)

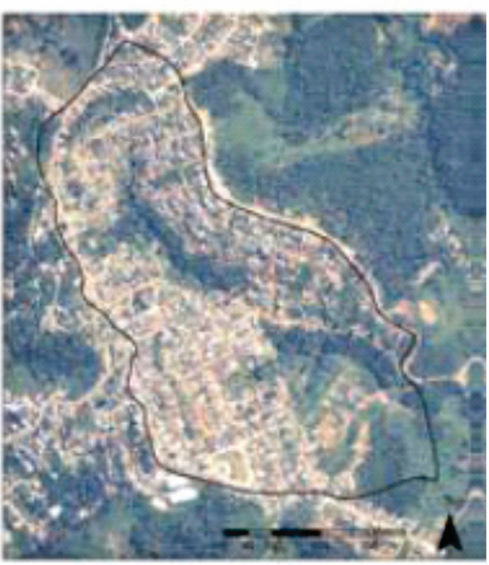

Imagem de Satélite IKONOS de 2007

Imagem 1. Evolução da ocupação da Microbacia Taquara do Reino

FONTE: SATO, 2011, adaptado

Segundo dados coletados no Censo 2010 (IBGE, 2010), a região da microbacia Taquara do Reino possuía mais de 1.950 edificações e uma população que somava mais de 5.500 moradores, o que resulta em uma densidade demográfica média de $13.214 \mathrm{hab} / \mathrm{km}^{2}$, podendo atingir até $22.973 \mathrm{hab} / \mathrm{km}^{2} \mathrm{em}$ alguns setores da margem direita da microbacia, números estes semelhante à de cidades como Daca, com 19.447 hab/km², Teerã, com 11.886 hab/km² e Lagos, com 16.067 hab/km². 
Dados compilados da sinopse dos setores censitários que ocupam a microbacia demonstram que, além do equilíbrio entre os gêneros e do ligeiro estreitamento em sua base, apresentando taxas menores de crescimento e aumento da expectativa de vida, a microbacia ainda apresenta uma população majoritariamente jovem, concentrada entre zero e 30 anos de idade, conforme demonstrado pelo gráfico 3 abaixo:

\section{Pirâmide etária Microbacia Taquara do Reino - Censo 2010}

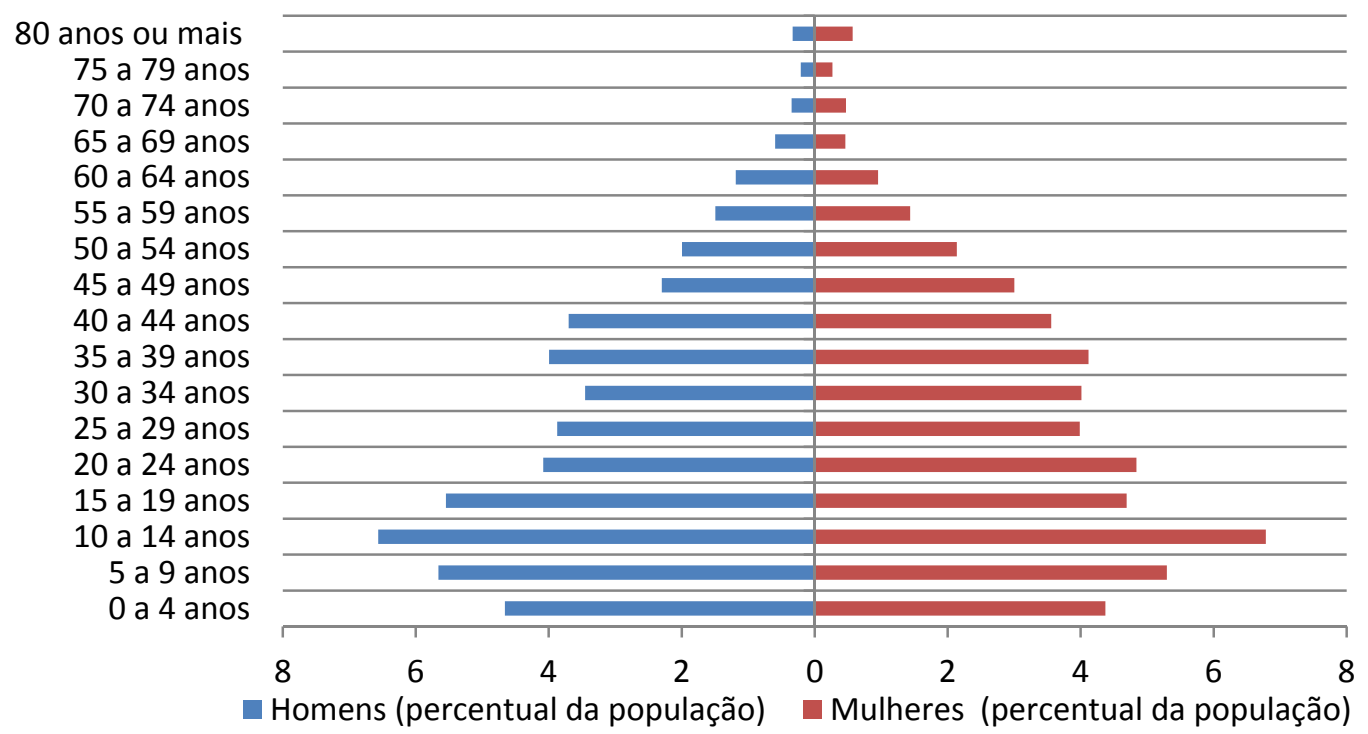

Gráfico 3. Pirâmide etária microbacia Taquara do Reino - Censo 2010

Fonte: Censo 2010, IBGE. Elaboração: Paulo Roberto Gaudio de Almeida.

A região da microbacia conta com três estabelecimentos públicos de ensino, um estabelecimento conveniado de educação básica além de apenas uma Unidade Básica de Saúde. Não há qualquer outro equipamento social na área, nenhuma estrutura de segurança pública, como posto policial ou corpo de bombeiros, existindo apenas uma praça como área de lazer, embora esteja bastante degradada e ocupada por ponto final de diversas linhas de ônibus

Além da precariedade da infraestrutura, apesar de $99 \%$ dos domicílios serem abastecidos com água da rede geral, $25 \%$ dos domicílios não possuíam coleta de esgoto, sendo despejados em rios ou depositados em fossas, o que pode potencializar o risco de escorregamentos com a penetração da água servida no solo das encostas. 


\section{Condições Gerais de Saneamento Básico na Microbacia \\ Taquara do Reino - Censo 2010}

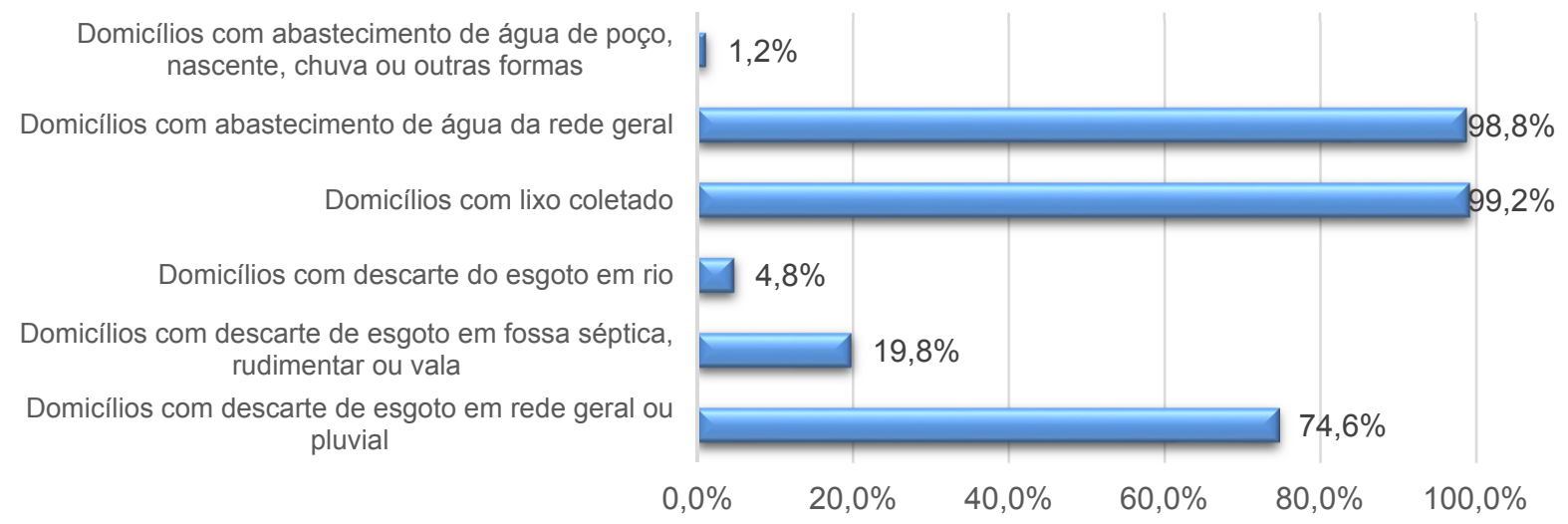

Gráfico 4. Condições Gerais de Saneamento Básico na microbacia Taquara do Reino.

Fonte: Censo 2010, IBGE. Elaboração: Paulo Roberto Gaudio de Almeida

Embora a população residente esteja bem distribuída entre homens e mulheres, há um grande desequilíbrio nesta distribuição quando comparados os responsáveis (segundo o gênero) pelo domicílio em áreas de maior e menor risco aos movimentos de massa.

Foram agrupados os setores da microbacia que possuem maior parte de sua área com declividades entre 30 e 45\% (área de uso restrito, com edificação autorizada mediante estudos técnicos) e acima de $45 \%$ de declividade (zona de proibição de parcelamento do solo), sendo considerados setores de situação geomorfológica crítica, e setores com declividades menores, sendo considerados em situação geomorfológica moderada. Notou-se que nos setores de situação crítica, há o predomínio de responsáveis pelo domicílio do sexo feminino, em uma nítida relação entre fragilidade ambiental e vulnerabilidade social, enquanto nos setores de situação moderada, há o predomínio maior de responsáveis do sexo masculino em uma proporção ainda maior, conforme demonstra o gráfico 5 : 

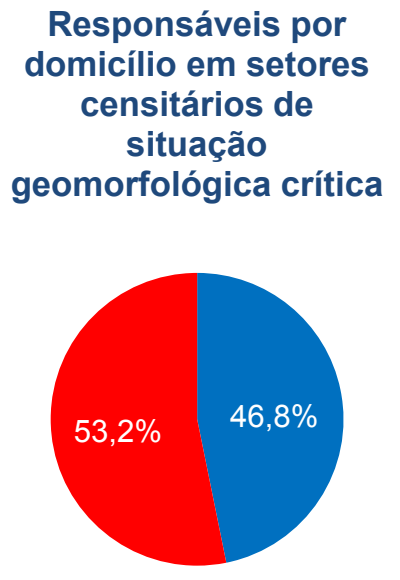

- Homens Mulheres

\author{
Responsáveis por \\ domicílio em setores \\ censitários de \\ situação \\ geomorfológica \\ moderada
}

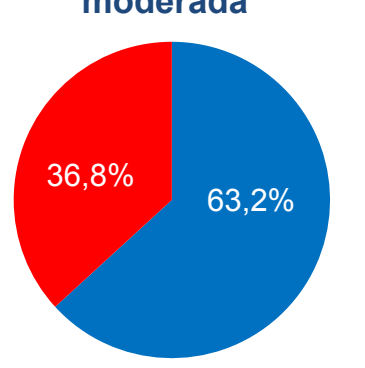

-Homens Mulheres
Total de moradores da Microbacia Taquara do Reino por gênero



-Homens mulheres

Gráfico 5. Gênero dos Responsáveis Por Domicílios Segundo Situação Geomorfológica.

Elaborado com dados do Censo 2010 e carta de declividade.

Nos setores de maior declividade e risco de escorregamento, em média 53\% dos responsáveis pelo domicílio são mulheres (podendo chegar a $70 \%$ nas piores áreas), ao passo que no setor de risco moderado os homens correspondem a $63 \%$ do total de responsáveis.

Para agravar ainda mais essa realidade, no setor de maior risco, $77 \%$ das mulheres responsáveis pelo domicílio não possuíam renda nominal em 2010, ao passo que para os homens, essa realidade é de $39 \%$ para o mesmo local. Além disso, nesse mesmo setor, $29 \%$ dos domicílios tinham renda per capita inferior a $\mathrm{R} \$ 1,00$ por dia.

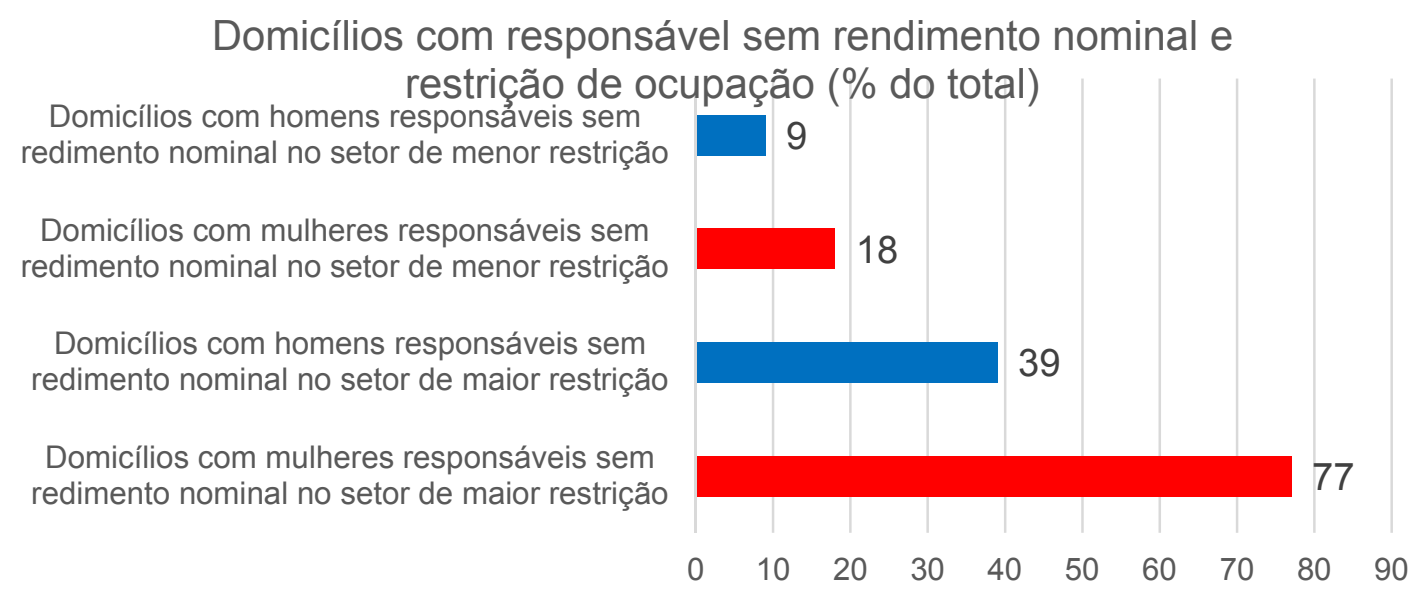

Gráfico 6. Domicílios com responsável sem rendimento nominal e restrição de ocupação. 
Os números referentes à educação também demonstram desigualdade entre as áreas de maior ou menor declividade e entre o gênero dos responsáveis pelo domicílio. Dados demonstram que em qualquer situação, as mulheres responsáveis pelo domicílio possuem alfabetização menor que a dos homens e, curiosamente, as mulheres em setores críticos possuem escolaridade maior do que as mulheres em setores moderados, conforme demonstra o gráfico 7:

Taxa de alfabetização de responsável por domicílio por gênero, de acordo com situação geomorfológica do setor

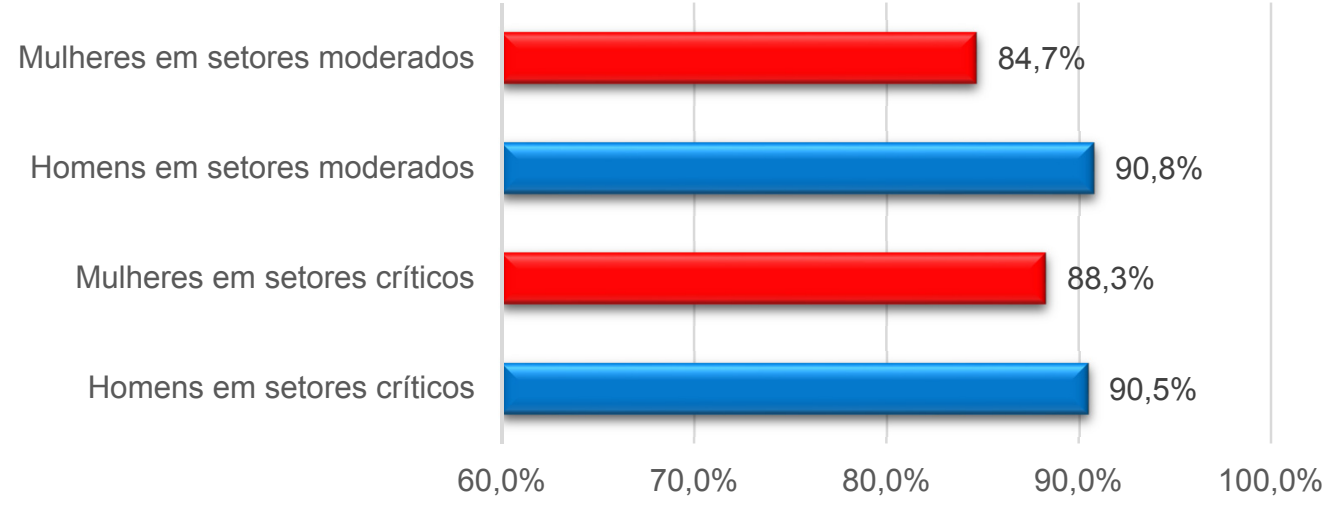

Gráfico 7. Taxa de alfabetização de responsável por domicílio por gênero, de acordo com situação geomorfológica do setor.

Fonte: Censo 2010, IBGE. Elaboração: Paulo Roberto Gaudio de Almeida

Os dados demonstram, portanto, que mesmo em situações de exclusão social e áreas de risco e exclusão da infraestrutura urbana, é possível existir desigualdade e heterogeneidade na condição de vida das pessoas, sendo as mulheres as mais afetadas pela desigualdade social e pelas más condições de habitação e risco.

\section{Usos e restrições na Bacia Taquara do Reino}

Toda a área da Microbacia Taquara do Reino está inserida na Macrozona de Uso Rural-Urbano - MUR-U - estabelecida pelo Plano Diretor do Município de Guarulhos (Lei Municipal 6055/2004), classificada como Zona Especial de Interesse Social - ZEIS-L - e Zona de Proteção e Desenvolvimento Sustentável - ZPDS-2 através da Lei de Uso, Ocupação e Parcelamento do Solo no Município de Guarulhos (Lei Municipal 6253/2007), além de estar enquadrada como Zona de Uso Sustentável e Recuperação Ambiental - ZUSRA - através da Lei de Criação da Área de Proteção Ambiental Cabuçu - Tanque Grande (Lei Municipal 6798/2010). 
Ao se somar todo o conjunto de restrições de zoneamento em MUR-R, ZEISL, ZPDS e ZUSRA, impostas pela legislação municipal sobre este loteamento, bem como às restrições impostas pela legislação federal, resumidamente temos as seguintes regras:

a) Proibição de edificação em faixa de 30 metros a partir dos cursos d'água e 50 metros no entorno de nascentes e olhos d'água;

b) Os lotes devem ter área mínima de $4000 \mathrm{~m}^{2}$ nas áreas de ZPDS-2;

c) Será exigido o licenciamento da SMA e demais órgãos quando houver: cortes ou aterros de mais de 3 metros; movimentação de mais de $1000 \mathrm{~m}^{3}$ de terra; em áreas com declividade superior a 30\%; áreas com processos erosivos; áreas que afetem ou alterem o escoamento das águas nos fundos de vale $\mathrm{e}$ áreas marginais a cursos d'água com até $5 \%$ de declividade;

d) As ações governamentais e as medidas tomadas devem estimular a preservação ambiental e a exploração econômica através de atividades ambientalmente sustentáveis como a agricultura familiar e a agroindústria, além da qualificação das moradias e construção de infraestrutura urbana, devendo possuir plano diretor participativo próprio;

e) Devem ser tomadas medidas mitigadoras e de recuperação ambiental das áreas dentro da APA, podendo coincidir com as ZEIS;

f) Todos os planos de urbanização devem obedecer às restrições e medidas contidas no plano de gestão da APA;

g) Uso restrito acima de $800 \mathrm{~m}$ de altitude dentro da área da APA, de modo a proteger os remanescentes significativos de vegetação, manutenção da biodiversidade e patrimônio histórico e cultural assim como os recursos hídricos;

h) É proibido o parcelamento do solo:

- Em áreas sujeitas à inundação sem antes serem realizadas obras para a resolução do problema;

- Em terrenos de declividade superior a 30\%, salvo com autorização de órgão competente e jamais em declividades superiores a $45 \%$;

- Em terrenos entre $30-45 \%$ de declividade somente perante relatório de viabilidade de técnico responsável, garantindo as exigências de segurança; 
- Em terrenos contíguos a mananciais, recursos hídricos ou vegetação arbórea;

- Ao longo de cursos d'água deve ser respeitada a distância de 15 metros de cada lado a partir da margem, atendendo as restrições de legislação estadual e federal;

- Sem condições geológicas adequadas à construção;

Dessa maneira, podemos comparar o mapa da atual ocupação da microbacia Taquara do Reino com o mapa de zoneamento, elaborado a partir das restrições mencionadas acima.

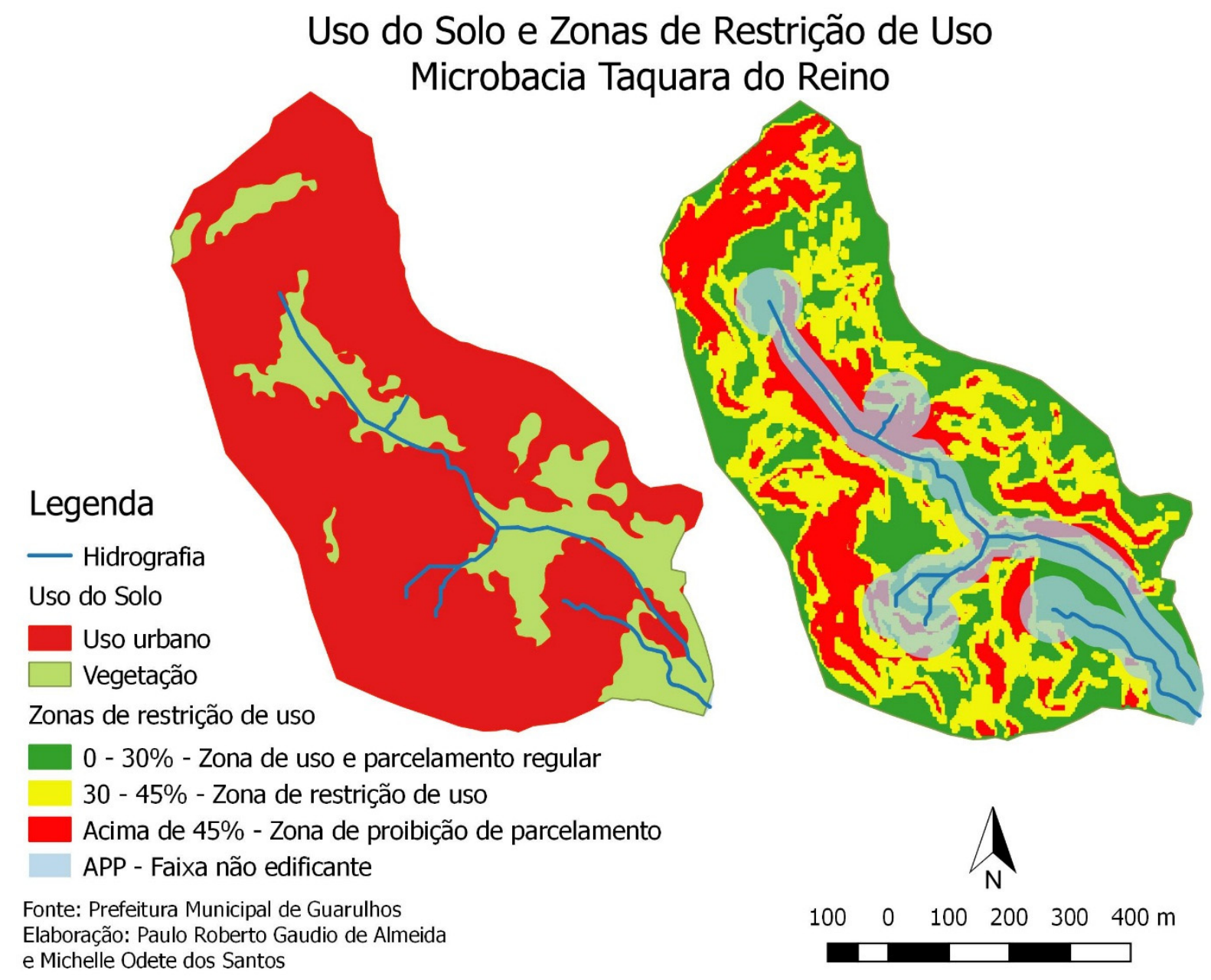

Mapa 19. Uso do Solo e Zonas de Restrição de Uso Microbacia Taquara do Reino

Analisando o mapa 19, pode-se verificar que dos 42 ha de área da microbacia, $34 \%$ possuem declividade entre 30 e 45\%, condição que exige a autorização da prefeitura mediante relatórios e laudos geotécnicos de aptidão para a construção, conforme já citado anteriormente. Outros $28 \%$ da área estão em declividade superior 
a 45\%, correspondendo às zonas de proibição de parcelamento do solo e, consequentemente, de edificação de moradias em lotes pequenos. Além disso, $24,7 \%$ do total da área está na faixa não edificante de entorno de rios e nascentes.

Contudo, nota-se através da comparação entre os mapas, que boa parte das edificações foram fixadas em áreas de restrição parcial ou total, resultando em condições que possibilitam a ocorrência de desastres tanto pela falta de padrões e normatizações adequados à construção nas áreas restritas (cumprindo as normatizações estabelecidas pela prefeitura), como também pela ocupação de áreas não edificáveis e de alto risco de escorregamento. O mapa 20 ilustra essa condição de moradia em zonas de restrição com o uso de ortofotografia da microbacia Taquara do Reino.

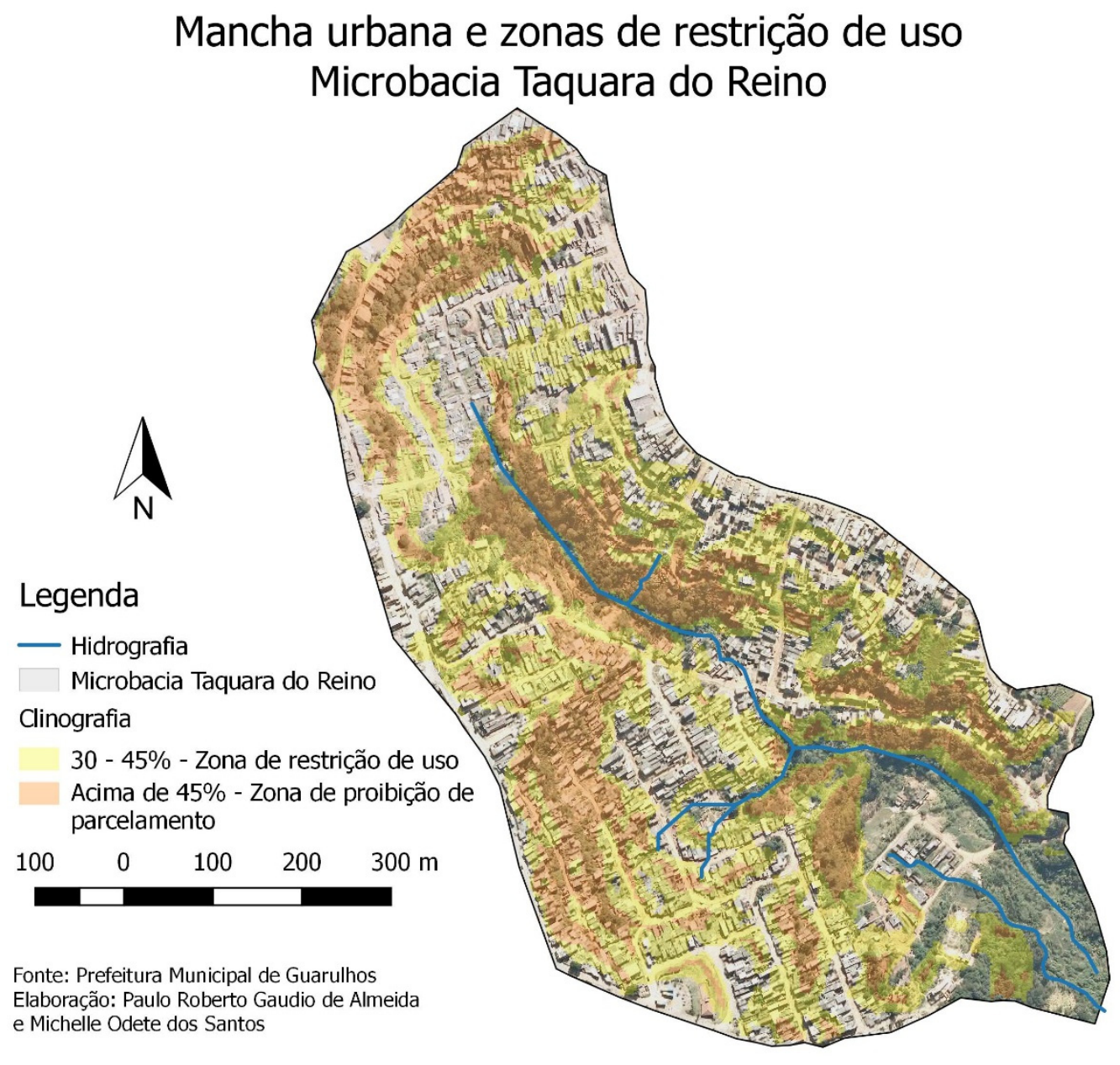

Mapa 20. Mancha urbana e zonas de restrição de uso Microbacia Taquara do Reino 


\section{Trabalho de campo}

No trabalho de campo foram detectadas diversas incompatibilidades com as normas de zoneamento estabelecidas pela prefeitura de Guarulhos e pela legislação federal.

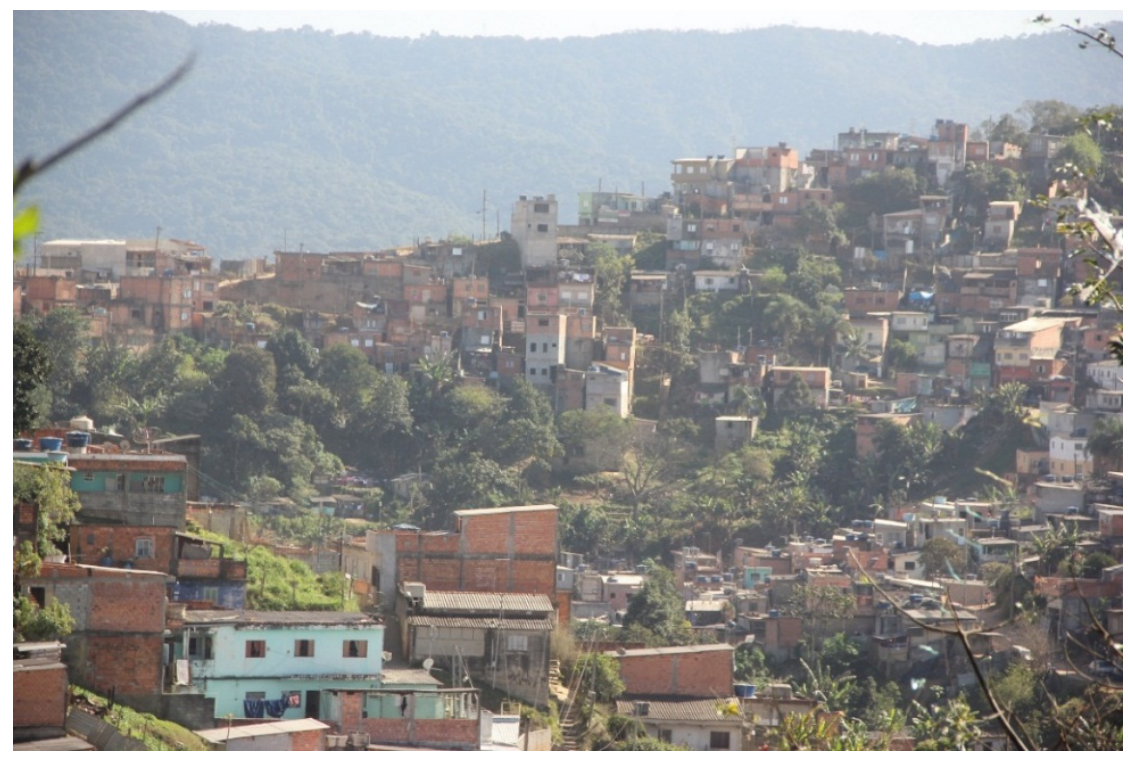

Imagem 2. Ocupação em vertente em anfiteatro. Paulo Roberto Gaudio de Almeida.

$\mathrm{Na}$ imagem 2 acima, é possível observar a ocupação das vertentes do anfiteatro e, consequentemente, das nascentes do córrego Taquara do Reino, na porção norte da microbacia. A legislação prevê a faixa não edificante de 50 metros de raio do ponto considerado como nascente do rio. Conforme já detectado na análise das ortofotografias, foi constatado em campo a ocupação da faixa não edificante. Além do prejuízo à captação de água para os rios, a construção de casas na faixa não edificante pode resultar em alagamentos nas regiões mais baixas da microbacia. 


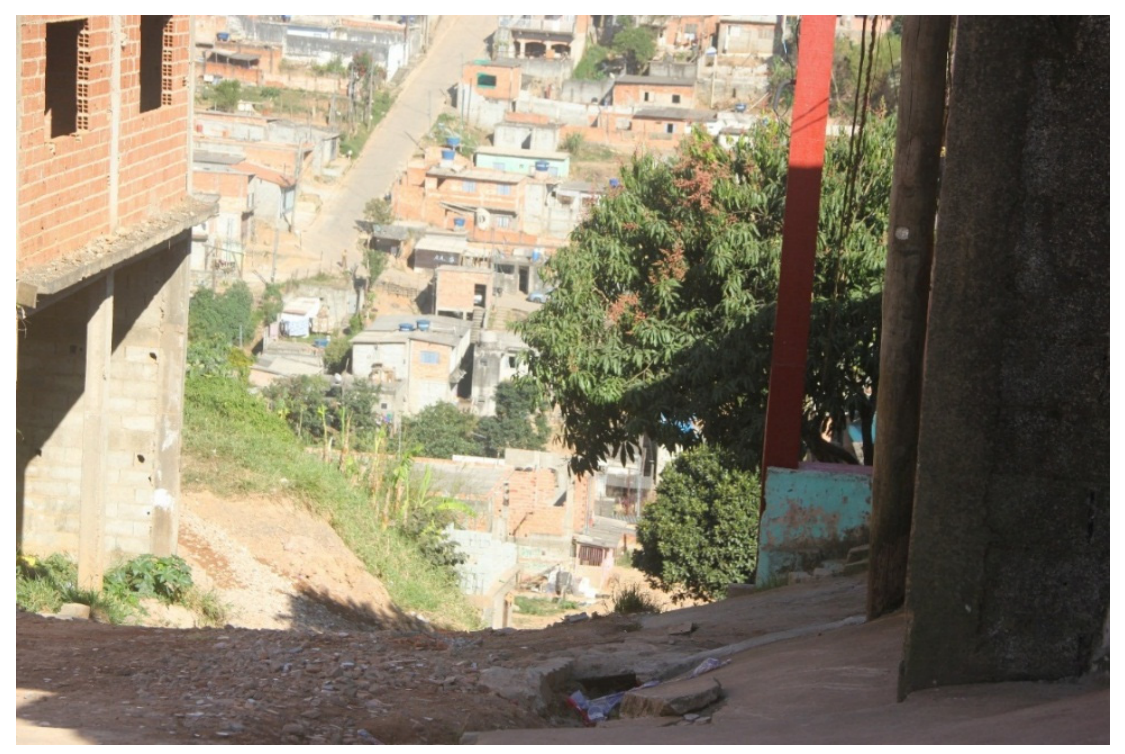

Imagem 3. Ocupação de vertente de alta declividade. Por Paulo Roberto Gaudio de Almeida.

$\mathrm{Na}$ imagem 3 é possível notar a acentuada declividade das vertentes da microbacia. Destaque para o arruamento que se direciona perpendicularmente ao fundo do vale, proporcionando vias bastante íngremes e gerando a possibilidade de fluxos torrenciais superficiais nos períodos de chuvas mais fortes.

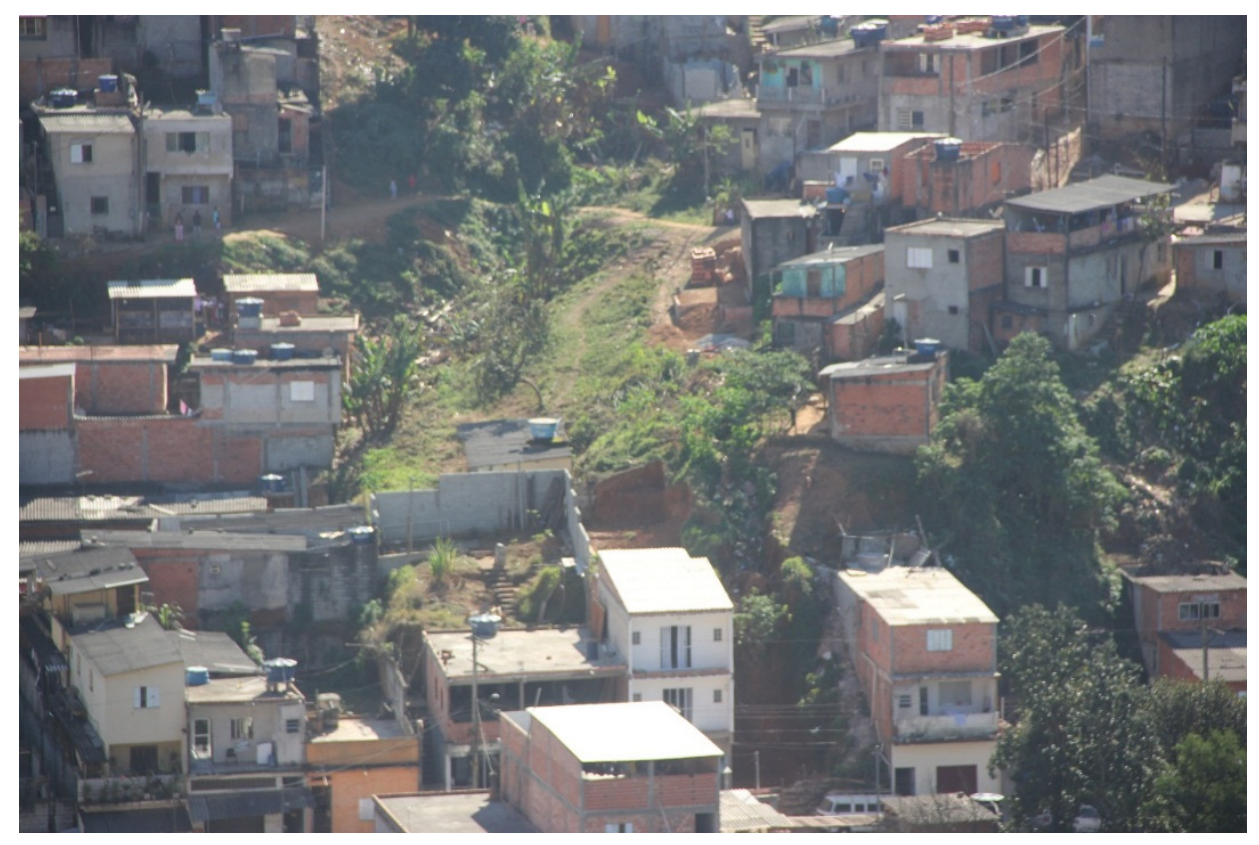

Imagem 4. Casas em risco de colapso. Por Paulo Roberto Gaudio de Almeida.

Foram observados diversos cortes de mais de 3 metros de amplitude vertical em relação à superfície adjacente à construção, realizados nas autoconstruções. Cortes verticais em encostas podem desestabilizar os materiais da vertente e provocar deslizamentos. 


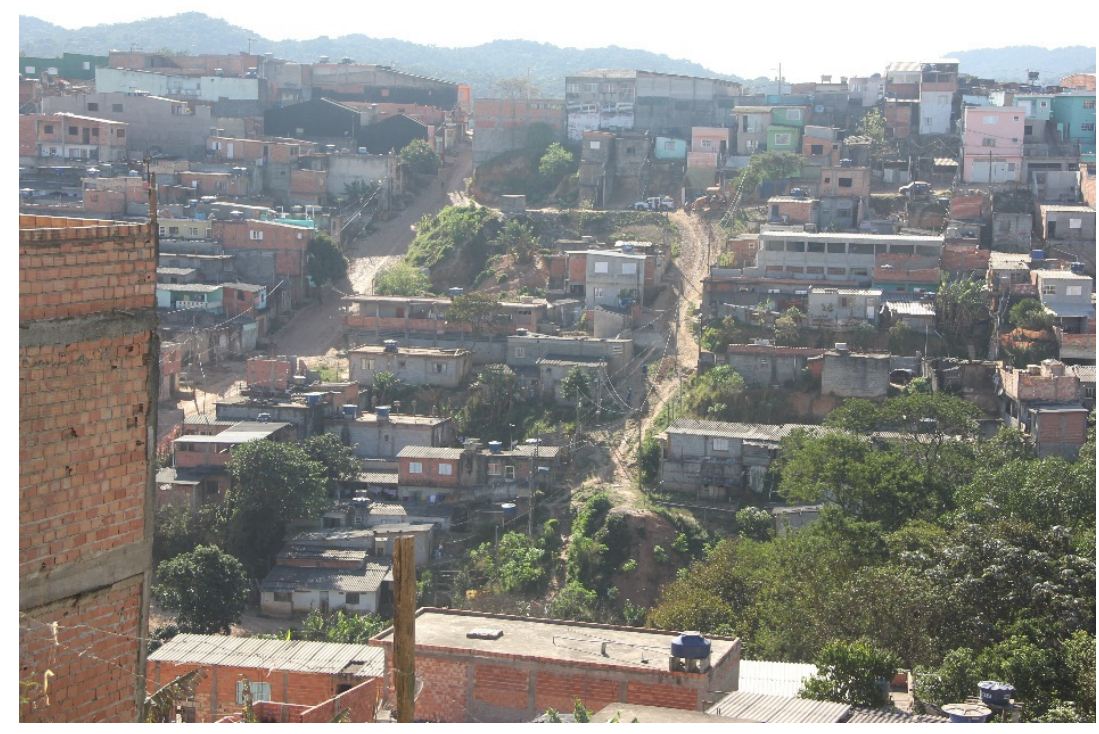

Imagem 5. Ruas perpendiculares ao talvegue do vale na microbacia Taquara do Reino. Por Paulo Roberto Gaudio de Almeida.

Foram encontradas diversas situações de construções em risco de colapso, como as demonstradas nas imagens 6,7 e 8 :

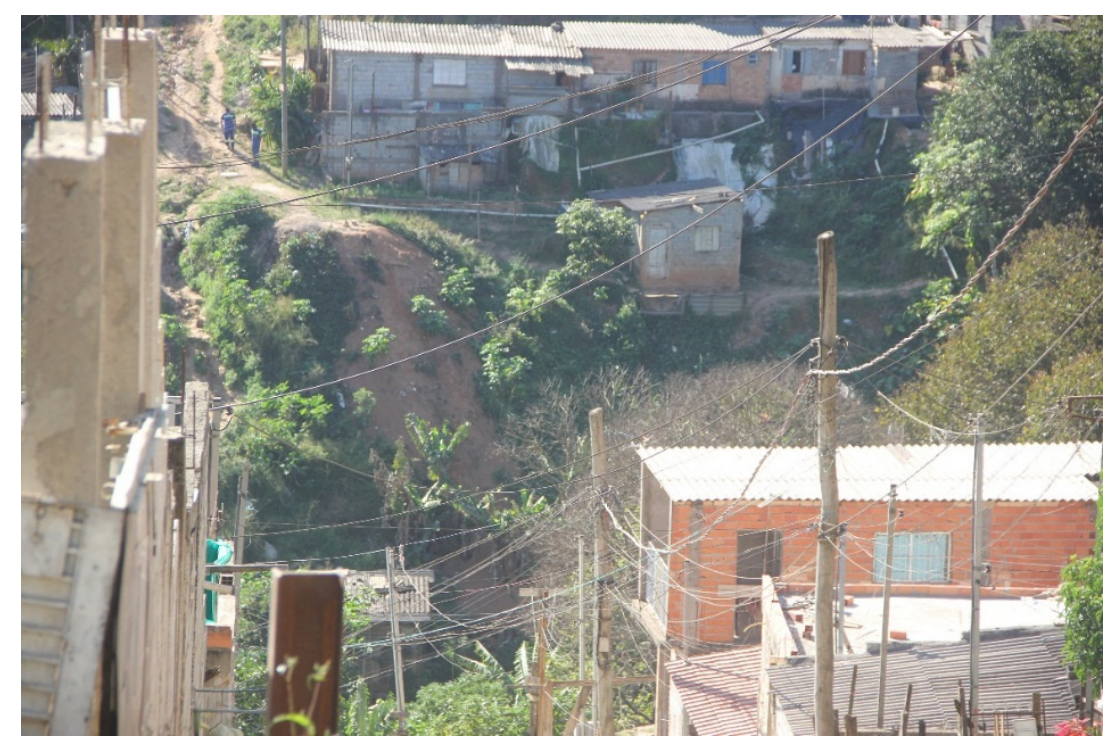

Imagem 6. Casa em risco de colapso na microbacia Taquara do Reino. Por Paulo Roberto Gaudio de Almeida. 


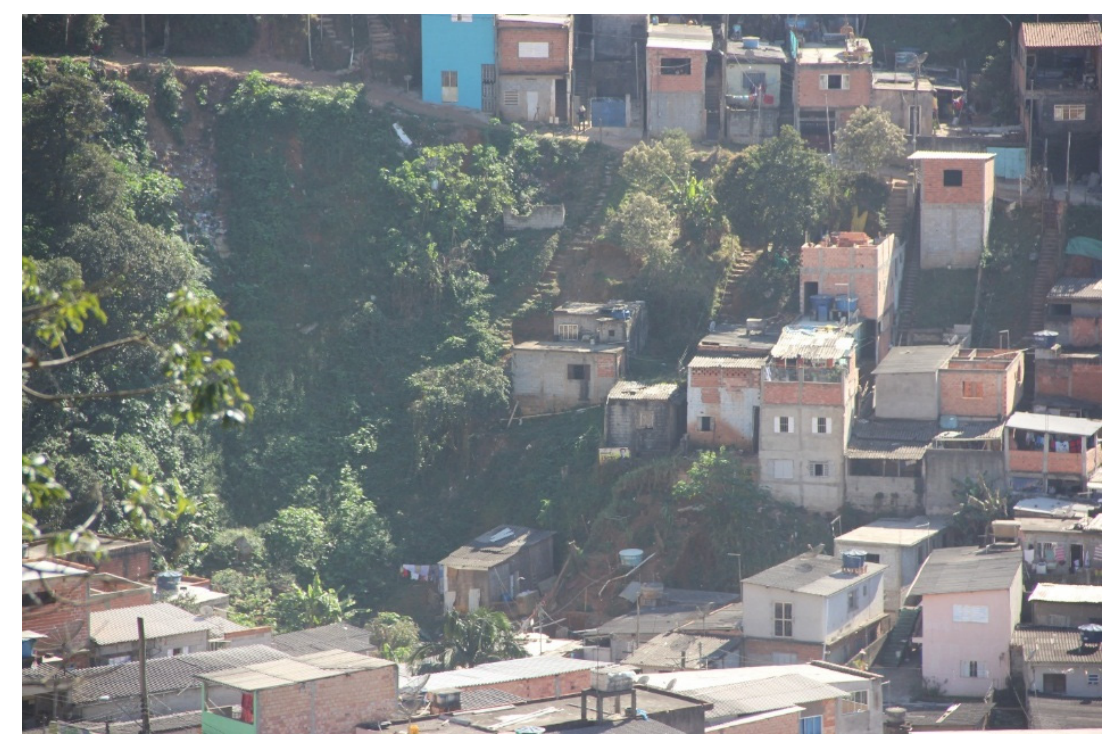

Imagem 7. Rua e casas em risco de colapso na microbacia Taquara do Reino. Por Paulo Roberto Gaudio de Almeida.

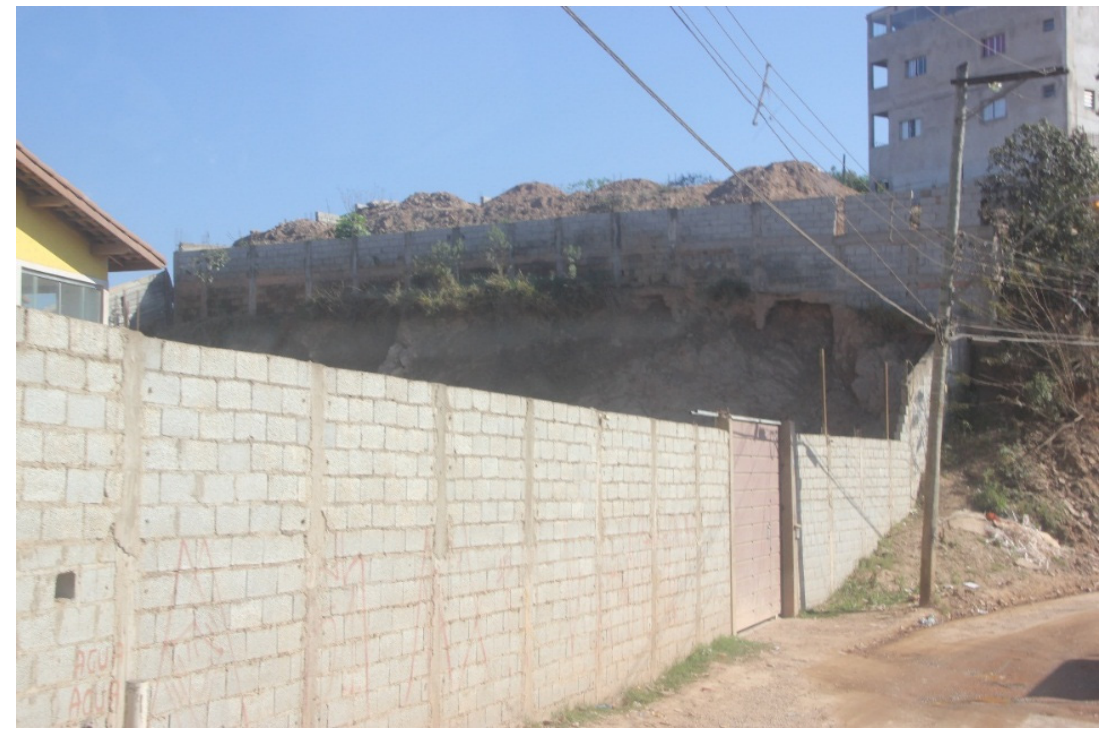

Imagem 8. Muro em risco de colapso na microbacia Taquara do Reino. Por Paulo Roberto Gaudio de Almeida.

O arruamento que circunda a microbacia foi construído na crista dos morros e nos divisores de águas e se encontra, em certas circunstâncias, também à beira de colapso, conforme observado na imagem 7. Em alguns pontos foram localizados pequenos escorregamentos das encostas marginais à via, em cortes verticais realizados nas autoconstruções conforme imagens 9 e 10: 


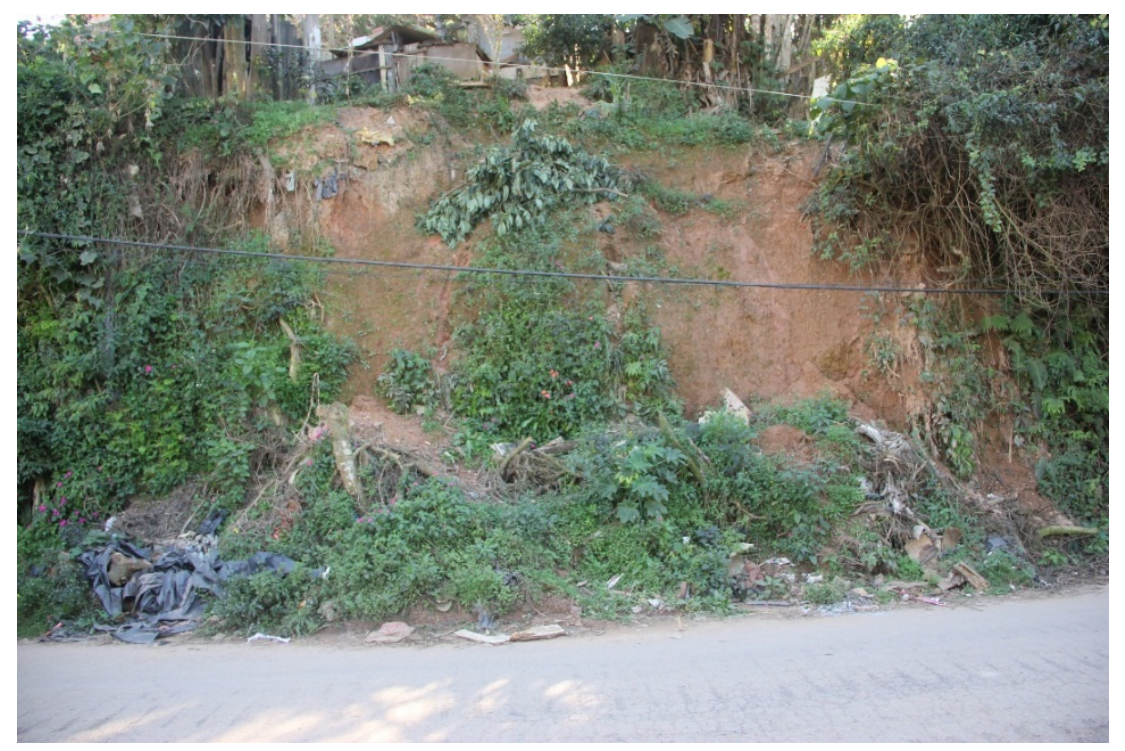

Imagem 9. Escorregamento em vertente da microbacia Taquara do Reino. Por Paulo Roberto Gaudio de Almeida.

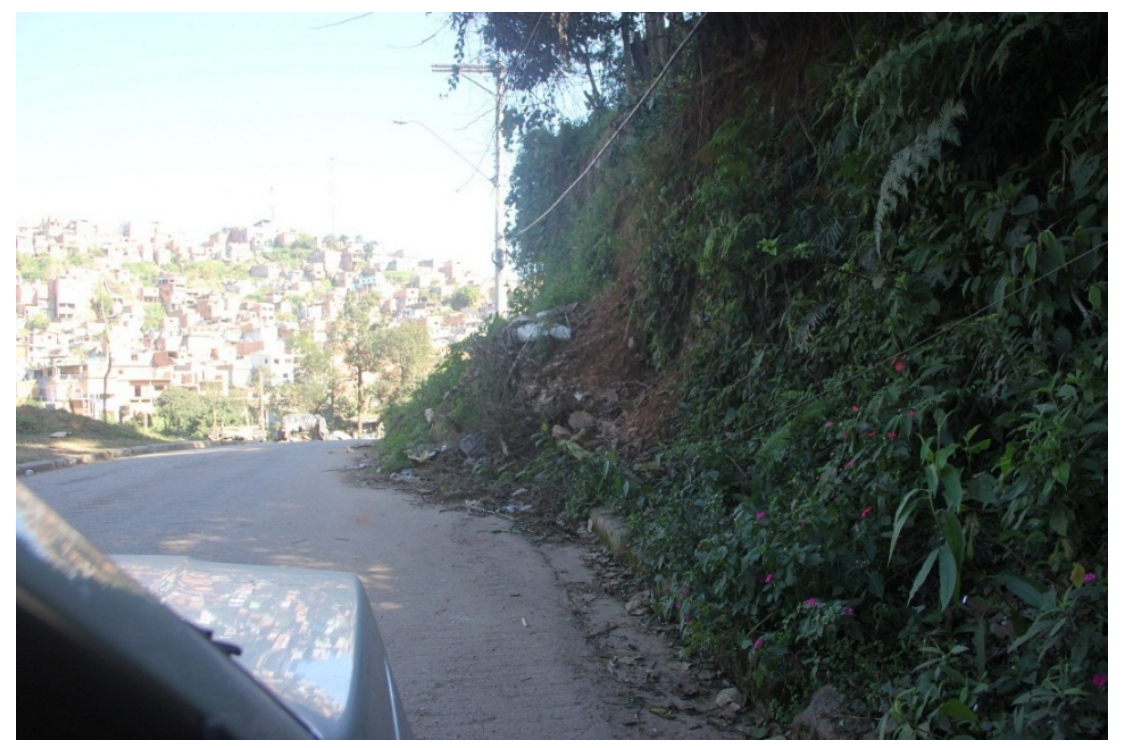

Imagem 10. Escorregamento em vertente da microbacia Taquara do Reino. Por Paulo Roberto Gaudio de Almeida.

Outro grave problema encontrado foi o fato de as vias de circulação terem sido pavimentadas com bloquetes de concreto nas cristas divisoras de águas e asfaltadas nas porções mais baixas da microbacia. É fato notório que vias pavimentadas com materiais permeáveis, em linhas de cumeada, permitem a infiltração da água das chuvas, bem como da água servida no solo da encosta, podendo provocar a desagregação dos materiais, sua instabilidade e seu escorregamento.

Por outro lado, vias em locais mais planos e próximas aos rios, quando pavimentadas com asfalto, dificultarão a penetração de água das chuvas, aumentando assim a circulação superficial, podendo provocar alagamentos. 


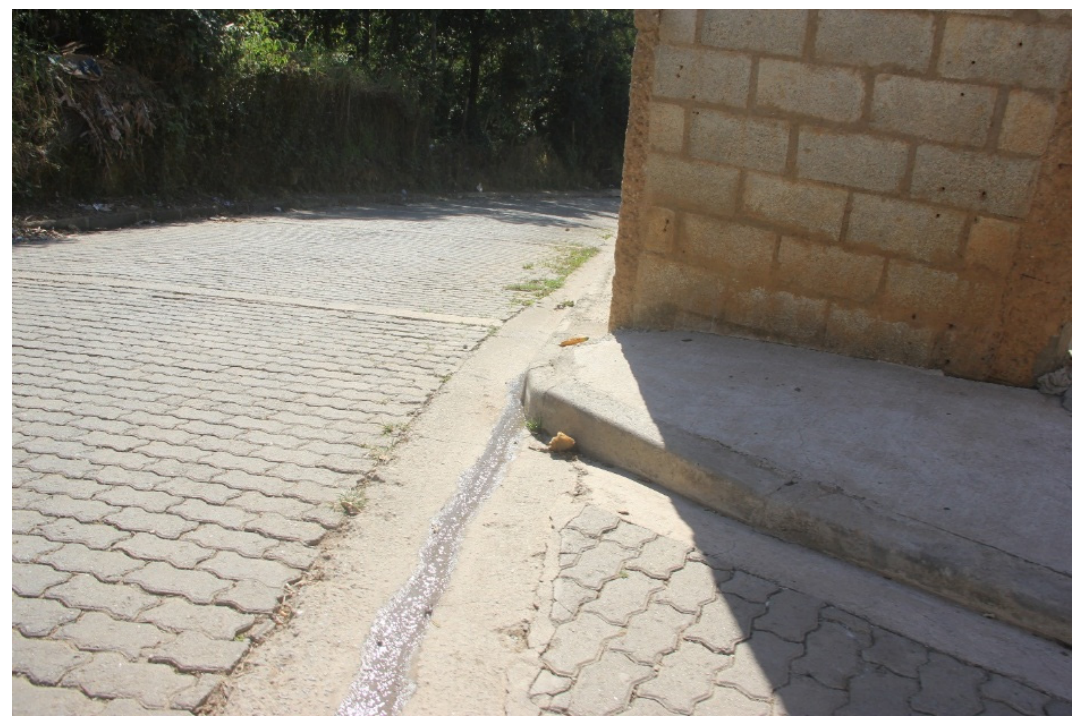

Imagem 11. Rua pavimentada com bloquetes de cimento na microbacia Taquara do Reino. Por Paulo Roberto Gaudio de Almeida.

Além disso, também foi observado o descarte irregular de lixo e entulho ao longo das encostas, conforme mostra a imagem 12:



Imagem 12. Descarte de lixo em encosta na microbacia Taquara do Reino. Por Paulo Roberto Gaudio de Almeida. 


\section{Discussão}

Após a análise da legislação e das condições encontradas na ocupação da área de estudo, torna-se possível fazer diversas observações sobre as práticas do planejamento urbano, a formalização das leis e a realidade das condições de habitação das zonas periféricas das grandes metrópoles.

Em princípio, as leis de zoneamento, sejam elas elaboradas em nível federal, estadual ou municipal, tem como objetivo, em linhas gerais, a preservação dos recursos naturais e seu uso sustentável, a garantia do bem estar da população, o direito à moradia digna, o estímulo ás atividades econômicas e a geração de emprego, a preservação do patrimônio histórico e natural, além de estabelecer um determinado ordenamento do uso e da ocupação do solo. Contudo, nem sempre este objetivo é alcançado ou, por vezes, o planejamento torna-se uma ferramenta de especulação imobiliária para a valorização de determinadas áreas do município.

No que diz respeito às normas de ocupação estabelecidas pela legislação municipal de Guarulhos, é possível notar não apenas uma preocupação com o bem estar social e a preservação ambiental, mas acima de questões burocráticas e normativas, a legislação de zoneamento e ocupação do território tem por base critérios geotécnicos bastante claros, seguindo a própria legislação federal: várzeas podem sofrer inundações e vertentes de maior declividade podem sofrer escorregamentos. A ocupação dessas áreas, ainda que sob critérios técnicos extremamente rigorosos, pode resultar em problemas estruturais ou ainda em tragédias irreparáveis.

Contudo, através da instituição das ZEIS, a legislação passa a autorizar a edificação dentro de áreas que, segundo os critérios técnicos estabelecidos pela própria lei, seriam inapropriadas para a habitação humana. É fato que se tratam, geralmente, de áreas extremamente pobres e carentes de todo o tipo de infraestrutura urbana, como no caso da microbacia Taquara do Reino. Entretanto, a simples regularização fundiária, obras de saneamento e projetos de urbanização (iluminação, calçamento, pavimentação, etc.) não alteram o fato de se tratar de uma região com $34 \%$ de sua área total com declividade entre 30 e $45 \%$, e $28 \%$ em áreas com declividade superior a $45 \%$, além de $24,7 \%$ do total da área estar na faixa não edificante de entorno de rios e nascentes (conforme mapa 20), o que por si só deveriam ser os primeiros critérios a serem respeitados no planejamento ambiental. 
Além do mais, foi constatado em campo que o arruamento existente foi pavimentado parcialmente, sem nenhum tipo de reordenamento de seu traçado com vistas à melhoria do escoamento superficial. Ruas perpendiculares ao talvegue do fundo do vale e também estabelecidas sobre a linha de cumeada foram mantidas. No primeiro caso, próximo ao fundo do vale, as ruas foram pavimentadas com asfalto, impermeabilizando o solo e prejudicando a absorção de água das chuvas. No segundo caso, as ruas que estão nas partes mais altas foram pavimentadas com bloquetes de cimento, permitindo a infiltração de água das chuvas nas porções mais altas das vertentes, o que pode ocasionar a saturação do solo e sua consequente instabilidade, resultando em escorregamento das encostas. Outro fato importante a ser destacado foi a enorme quantidade de ruas ainda sem pavimentação ou drenagem adequadas.

Há ainda que se considerar a qualidade técnica da construção das residências. No estágio em que se encontram instaladas nas encostas, é praticamente impossível se estabelecer qualquer parecer técnico sobre as condições de segurança das fundações e da resistência das habitações ali estabelecidas. Conforme visto nas imagens 5, 6 e 7, existem diversas construções de mais de cinco pavimentos verticais sobre vertentes de mais de $75 \%$ de declividade. O peso dessas construções associado à infiltração da água das chuvas nos períodos mais pluviosos pode levar à instabilidade das encostas. Além disso, há que se considerar também a existência de falhamentos tectônicos na região, os quais sob a mínima movimentação podem provocar a ruptura dos limites de estabilidade e ocasionar deslizamentos.

A criação das ZEIS é um marco no direito à moradia voltado à população mais carente. Contudo, critérios físicos não podem ser abandonados em nome de políticas sociais, visto que, ao final do processo, tais regiões posteriormente "legalizadas" continuam às margens da sociedade devido às suas características físicas de difícil transformação, tais como a elevada altitude, a declividade acentuada e os arruamentos perpendiculares ao talvegue do vale. Essas características dificultam a locomoção dos habitantes no seu cotidiano, bem como o desenvolvimento de atividades econômicas.

Obviamente, não é possível deixar de lado o relacionamento das pessoas com o lugar em que vivem cotidianamente, onde são formados vínculos e enraizamentos, dinâmicas e estruturas econômicas, sociais, culturais e históricas. Porém, uma 
legislação que pretende estabelecer normas que ordenem o uso do espaço de maneira sustentável e priorizem o bem estar e a vida, não poderia apresentar brechas que possibilitem a existência de estruturas como as verificadas em campo.

Outro ponto a ser destacado é a sobreposição de zoneamentos em uma mesma área. Como pôde ser observado anteriormente, um mesmo local possui quatro tipos de zoneamento diferentes, com regras e leis incidentes umas sobre as outras, tornando sua interpretação uma tarefa dificultosa e confusa, visto que os textos das leis são rebuscados e pouco inteligíveis. Trocando em miúdos, a interpretação da lei levaria, em última instância, à impossibilidade de qualquer tipo de edificação na área da microbacia Taquara do Reino, dado o nível de complexidade de seus sistemas naturais e pelo fato de todos eles serem de restrição máxima de uso (área de manancial montanhosa, de vegetação nativa e elevada declividade).

Neste sentido, é necessário que se levante um questionamento acerca das práticas estabelecidas pelo poder público no que diz respeito à criação e aplicação de leis e que pretende ser objeto de estudos futuros: as leis e suas normatizações devem ser adaptadas à realidade ou a realidade deve se adaptar às leis? Até qual ponto uma realidade estabelecida pode ou deve ser adaptada a um novo conjunto de práticas?

No que diz respeito ao planejamento urbano e ambiental, as dúvidas não são diferentes. Embora inúmeras restrições de uso e ocupação do solo sejam discutidas e estabelecidas desde os primeiros planos de zoneamento e urbanização, também é fato notório que as condições de construção dos espaços urbanos e de fiscalização do poder público sempre foram precárias (quando não foram negligentes), gerando uma quantidade enorme de espaços periféricos completamente irregulares ao longo de nossa história. Seja do ponto de vista fundiário, seja do ponto de vista geotécnico, boa parte da periferia das grandes metrópoles brasileiras sofre com diversos problemas legais e estruturais, demonstrando no mínimo, uma falha ou de planejamento ou de execução de suas regras.

Dessa maneira, torna-se importante levantar outro questionamento sobre as práticas de planejamento urbano e ambiental, principalmente no caso da geomorfologia ambiental: estariam os profissionais do planejamento e o poder público praticando o planejamento ambiental ou a remediação ambiental? É desnecessário salientar que qualquer planejamento é melhor que nenhum planejamento, mas 
também é nítido o descompasso entre as regras de ocupação do espaço e a realidade da urbanização brasileira.

Constata-se, assim, a necessidade de estudos mais aprofundados acerca dos processos e critérios técnicos utilizados para a elaboração não apenas da legislação ambiental, mas também de todo o planejamento urbano e ambiental. Contudo, devese cobrar do poder público o respeito à legislação e os estudos executados por órgãos competentes, uma vez que o Estado é responsável tanto pelo parcelamento do solo quanto pelas políticas de consolidação e regulamentação de assentamentos, muitas vezes conflitantes com a realidade das autoconstruções.

\section{Considerações Finais}

A análise constatou que embora existam diversas normatizações de uso e ocupação do solo estabelecidas pelo planejamento urbano e ambiental através de variadas leis para áreas com risco de movimento de massa, a microbacia Taquara do Reino terminou por ser enquadrada pela Prefeitura Municipal de Guarulhos como Zona Especial de Interesse Social, permitindo a ocupação para finalidades habitacionais de uma área considerada imprópria para tal propósito pelas leis e diretrizes de ordenamento urbano estabelecidas pelo próprio poder público.

Dessa forma, o mesmo poder que institui as leis restritivas ao uso da terra é também o poder que permite exceções em seu uso, colocando em risco a população que habita áreas impróprias à fixação humana. 


\section{Bibliografia}

ABREU, A. A. Análise geomorfológica: reflexão e aplicação. Tese de livre-docência, São Paulo, 1982

AB'SABER, A.N. Bases Conceituais e Papel do Conhecimento na Previsão de Impactos. In: MÜLER, Clarita, Plantenberg e Azis AB' Saber (ORGS). Avaliação de Impactos. 1994. p. 27 - 50.

AB'SABER, A.N. Um conceito de Geomorfologia serviço das pesquisas sobre o Quartenário. Instituito de Geografia, São Paulo, 1969

AB'SABER, A. N.; MULLER- PlANTEMBERG, C. Previsão de Impactos: o estudo de impactos ambientais no leste, oeste e sul: experiências no Brasil, na Rússia e na Alemanha. 2. ed. São Paulo: USP, 2006. 571 p.

ADEODATO, M. T. P. C. A razão e os limites das Políticas Nacionais de desenvolvimento urbano: uma análise comparativa das proposições de 1975 e 2004. Tese de doutorado, São Paulo, 2010

ANDRADE, M. R. M. Planejamento ambiental da APA Cabuçu-Tanque Grande Guarulhos-SP. Tese de doutorado, São Paulo, 2009

ARAUJO, G. H. S. Gestão Ambiental de área degradadas/ Gustavo Henrique de Sousa Araujo, Josimar Ribeiro de Almeida, Antonio José Teixeira Guerra. - $11^{\text {a }}$ ed. Rio de Janeiro: Betrand Brasil, 2014.

BAITELLO, J.B. et al. Estrutura fitossociológica da vegetação arbórea da Serra da Cantareira (SP) - Núcleo Pinheirinho. Rev. Inst. Flor., v. 5, n. 2, p.133-161, 1993.

BERTRAND, G. Paisagem e geografia física global - esboço metodológico. Caderno de Ciências da Terra - Instituto de Geografia - USP, 1972. 13: 1-27,

BITAR, O. Y. (Coord.). Cartas de suscetibilidade a movimentos gravitacionais de massa e inundações: 1:25.000 (livro eletrônico): nota técnica explicativa, São Paulo: IPT - Instituto de Pesquisas Tecnológicas do Estado de São Paulo; Brasília, DF: CPRM - Serviço Geológico do Brasil, 2014 
BONETT, J. N. Planejamento urbano e formas ideológicas no Brasil. O caso de São Paulo. Dissertação de mestrado, São Paulo, 2014

BONFIM, P. R. A. A Ostentação Estatística (um projeto geopolítico para o território nacional: Estado e planejamento no período pós-64). Tese de doutorado, São Paulo, 2007.

BRASIL. Constituição da República Federativa do Brasil. Brasília. 1967.

. Constituição da República Federativa do Brasil. Brasília. 1988.

. Estatuto da cidade. Guia para implementação pelos municípios e cidadãos.

Brasília, 2001

. Lei $\mathrm{n}^{\circ} 10.257$, de 10 de julho de 2001. Estatuto da Cidade. Legislação

Federal.

Disponível

em:

http://www.planalto.gov.br/ccivil 03/leis/leis 2001/l10257.htm Acesso em: out. 2014

. Lei $\mathrm{n}^{\circ} 11$, de 22 de dezembro de 2006. Dispõe sobre a utilização e proteção da vegetação nativa do Bioma Mata Atlântica, e dá outras providências. Legislação Federal. Disponível em: www.planalto.gov.br/ccivil 03/ ato20042006/2006/lei/l11428.htm Acesso em: maio 2016 . Lei n ${ }^{0}$ 12.608, de 10 de abril de 2012. Política Nacional de Proteção e Defesa

Civil - PNPDEC. Legislação Federal. Disponível em:
http://www.planalto.gov.br/ccivil 03/ Ato2011-2014/2012/Lei/L12608.htm Acesso em: out. 2014

. Manual de desastres naturais. Volume I, Brasília, 2003

BUSTAMANTE, T.G.C. Impactos da chuva na ocorrência de deslizamentos de terra e inundações no Estado de São Paulo. Dissertação de mestrado, INPE, São José dos Campos, 2010

CARVALHO, C. S.; GALVÃO, T (ORGS.). Prevenção de riscos de deslizamentos em encostas: guia para elaboração de política municipais. Ministério das Cidades, Brasília, 2006 
CARVALHO, C. S.; MACEDO, E. S.; OGURA, A. T.(Orgs). Mapeamento de Riscos em Encostas e Margem de Rios. Ministério das Cidades, Instituto de Pesquisas Tecnológicas - IPT, Brasília, 2007.

CASSETI, V. Elementos de Geomorfologia. Editora da UFG, Goiânia, 1994

CASSETI, V. Geomorfologia. Livro Digital. Disponível em http://www.funape.org.br/geomorfologial. Acesso em: jan. 2015

CASTRO, A. L. C. Manual De Desastres. Desastres Naturais. v.1, Brasília, 2003

COlANGELO, A. C. Carta de feições mínimas. In: XIV Congresso Brasileiro de Cartografia, 1989, Gramado. Anais do XIV Congresso Brasileiro de Cartografia, 1989. v. 2. p. $375-380$.

COLANGELO, A. C. O modelo de feições mínimas ou das unidades elementares de relevo. Revista do Departamento de Geografia (USP), São Paulo, v. 10, p. 29-40, 1996

COSTA, G. M. Planejamento urbano: conceitos, princípios e perspectivas. $5^{\circ}$ CONGRESSO BRASILEIRO DE GEÓGRAFOS, Anais... São Paulo: Associação de Geógrafos do Brasil,1994, p.519-528

CRISTOFOLETTI, A. Geomorfologia. Edgard Blücher, São Paulo, 1980

CRUDEN, D. M. \& VARNES, D. J. (1996). Landslides Types and Processes. In: Turner A.K. \& Schuster R.L. (Eds.) Landslides: Investigation and Mitigation. Transportation Research Board Special Report 247. National Academy Press, WA, 36-75.

CUNHA, S. B.; GUERRA, A. J. T. Geomorfologia e Meio Ambiente. Orgs. Ed. Bertrand Brasil, 394p. Rio de Janeiro: Bertrand Brasil, 1996. 394p.

DAVIS, W. M. The geographical cycle. Geogr. Journ. London, v.14, n.5, 1899, p. 481504

DEÁK, C.; SCHIFFER, S. (Org,) O processo de urbanização no Brasil. Edusp/Fapesp, São Paulo, 1999.

FILHO, A. T. Imagens de pitoresca confusão: a cidade colonial na América Portuguesa. REVISTA USP, n.57, São Paulo, março/maio 2003 p. 50-67 
FLORENZANO, T. Geomorfologia - Conceitos e tecnologias atuais. Oficina de textos, São Paulo, 2008

GUERRA, A. J. T.; MARÇAL, M. S. Geomorfologia Ambiental. 1. ed. Rio de Janeiro: Bertrand, 2006. v. 1. 192p.

GUERRA, A. J. T.; CUNHA, S. B. (Org.) Avaliação e perícia ambiental. 1. ed. RIO DE JANEIRO: BERTRAND BRASIL, 1999. v. 1. $261 \mathrm{p}$.

GUERRA, A. T., 1924-1968. Novo dicionário geológico-geomorfológico / Antônio Teixeira Guerra e Antônio José Teixeira Guerra - $6^{\mathrm{a}}$ ed. - Rio de Janeiro: Bertrand Brasil, 2008

INSTITUTO BRASILEIRO DE GEOGRAFIA ESTATÍTICA. Anuário estatístico do Brasil, v.71, Rio de Janeiro, 2011

INSTITUTO BRASILEIRO DE GEOGRAFIA ESTATÍTICA. Resultados do Censo 2010. Disponível em http://censo2010.ibge.gov.br/resultados. Acesso em: nov. 2014. INSTITUTO DE PESQUISAS TECNOLÓGICAS. Plano de Desenvolvimento Regional dos Mananciais do Subcomitê AltoTietê-Cabeceiras: Plano de Desenvolvimento e Proteção Ambiental - PDPA - e assessoria para elaboração das Leis Específicas. Relatório Técnico 131 578-205 20 de janeiro de 2014.

KLINK, H.J. Geoecologia e Regionalização Natural. São Paulo, Ed. IG-USP, 1981

KOHLSDORF, M. E. Ensaio sobre o pensamento urbanístico. Brasília, 1996.

KOZCIAK, S.- Análise determinística da estabilidade de vertentes na bacia do Rio Marumbi - Serra do Mar - Paraná. Tese de Doutorado, Curitiba, 2005

LOMBARDO, M. A. Ilhas de calor na metrópoles: o exemplo de São Paulo. São Paulo: Hucitec, 1985. 244p.

MACHADO, C.R.L. Trecho leste do rodoanel metropolitano de São Paulo: aplicação e comparação de metodologias de análise ambiental. In Rev. Geogr. Acadêmica v.6, n. 1 xiii, 2012 p. 25-37 
MARCELINO, E.V.; NUNES, L.H.; KOBIYAMA, M. Banco de dados de desastres naturais: Análise de dados globais e regionais. Caminhos de Geografia Uberlândia v. 6, n. 19,2006 p. $130-149$

MARTONNE, E. Tratado de Geografia Física. Juventud, Barcelona, 1964

MAZZEI, K. et al. Parecer Técnico Rodoanel Mario Covas - Trecho Norte. 2011.

MINISTÉRIO DAS CIDADES. Política nacional de desenvolvimento urbano. Brasil, 2004.

MINISTÉRIO DO INTERIOR. II Plano Nacional de Desenvolvimento; programa de ação do governo na área do desenvolvimento. Secretaria Geral.1975-79. Brasília, 1975.

MTE-RAIS. Desenvolvimento econômico. In: Prefeitura Municipal de Guarulhos PMG.

Disponível

em:

http://www.guarulhos.sp.gov.br/index.php?option=com content\&view=article\&id=99\& $\underline{\text { Itemid=1318. }}$. Acesso em: jan. 2015

MONTEIRO, C.A.F. A dinâmica climática e as chuvas do estado de São Paulo: estudo geográfico sob forma de atlas. São Paulo: IGEOG, 1973.

MOREIRA, C. V. R.; PIRES NETO, A. G. Clima e relevo. In: OlIVEIRA, A. M.; BRITO, S. N. A. Geologia de engenharia. São Paulo: ABGE, 1998. p. 89-99.

NIMER, E. Climatologia do Brasil. 2.ed. Rio de Janeiro: Fundação IBGE, 1989. 421p.

OLIVEIRA, F. A. O Estado e o urbano no Brasil. Espaço e Debates, n.6, São Paulo: NERU, 1982, p. 36

PREFEITURA MUNICIPAL DE GUARULHOS - PMG. LEI N 6.055. O Plano Diretor De Desenvolvimento Urbano, Econômico E Social Do Município De Guarulhos E Dá Outras Providências. Câmara Municipal, Guarulhos, 2004.

. LEI No 6.253. Dispõe sobre o Uso, a Ocupação e o Parcelamento do Solo no Município de Guarulhos e dá providências correlatas. Câmara Municipal, Guarulhos, 2007. 
. LEI N 6798. Dispõe sobre a criação da área de proteção ambiental cabuçu-tanque grande e dá providências correlatas. Câmara Municipal, Guarulhos, 2010.

. LEI No 7.355. Dispõe sobre medidas voltadas à Regularização Fundiária no Município de Guarulhos, revoga a Lei $n^{\circ}$ 6.804, de 15/02/2011, e dá outras providências. Câmara Municipal, Guarulhos, 2014.

- Plano Diretor de Drenagem - Diretrizes, Orientações e Propostas. Guarulhos, 2008.

. Plano Estratégico Municipal para Assentamentos Subnormais - PEMAS. Secretaria de Habitação da Prefeitura Municipal de Guarulhos, 2004.

. Plano Municipal de Água e Esgoto. Guarulhos, 2011.

- Plano Municipal de Habitação de Interesse Social para Guarulhos PLHIS. Guarulhos, 2011.

QUEIROZ NETO, J.P. Análise estrutural da cobertura pedológica: Uma experiência de ensino e pesquisa. Revista do Departamento de Geografia, 15, 2002, p. 77-90

RODRIGUES, C.; MOROZ, I. C. A importância do fator antrópico na redefinição de processos geomorfológicos e riscos associados em áreas urbanizadas do meio tropical úmido. Exemplos $\mathrm{Na}$ Grande São Paulo. In: Antonio José Teixeira Guerra;Maria do Carmo Oliveira Jorge. (Org.). Processos Erosivos e Recuperação de Áreas Degradadas. $1^{\mathrm{a}}$ ed. São Paulo: Oficina de Textos, 2013, p. 01-192.

ROSA e BINDONE. Plano Municipal de Redução de Riscos. Guarulhos, 2004

ROSS, J. L. S. Análise Empírica da Fragilidade Dos Ambientes Naturais e Antropizados. Laboratório de Geomorfologia, Depto. de Geografia, FFLCH/USP, São Paulo, 1993

- Geomorfologia, Ambiente e Planejamento. Editora Contexto, São

Paulo, 1990 
. O registro cartográfico dos fatos geomórficos e a questão da taxonomia do relevo. Revista do Departamento de Geografia, FFLCH-USP, Sâo Paulo, v.6, 1992, p. $17-29$

SATO, S. E.; OlIVEIRA, A. M. S.; SAWAYA, S. B.; HERLING, T. B. R.; MORETTI, R. S.; GOMES, G. L. C. C. Estudo de urbanização em áreas de risco a escorregamentos nos loteamentos do Recreio São Jorge e Novo Recreio, região do Cabuçu, Guarulhos (SP), Brasil. Paisagem Ambiente: ensaios n. 29. São Paulo, 2011, p. 57 - 82

SCHÜRMANN, B. Urbanização Colonial na América Latina: Planejamento Urbano versus desleixo e Caos. Em Textos de História, no. 7, Revista do Programa de Pós Graduação em História, Universidade de Brasília, 1999.

SEADE. Perfil da Região Metropolitana de São Paulo. Disponível em. Acesso em: jan. 2015.

SEPE, P. M.; TAKIYA, H. Atlas Ambiental do município de São Paulo: o verde, o território, o ser humano. Diagnóstico e bases para a definição de políticas públicas para áreas verdes no município de São Paulo. São Paulo, SVMA, 2004, 257 p.

SIQUEIRA, R. M. B; \& Henry-Silva, G. G. A bacia hidrográfica como unidade de estudo e o funcionamento dos ecossistemas fluviais. Boletim da Associação Brasileira de Limnologia - 39(2). 2011

SOTCHAVA, V. B. O estudo de geossistemas. Instituto de Geografia. USP, São Paulo: Ed. Lunar, 1977.

TARIFA, J. R., ARMANI, G. Os climas "Naturais". In: TARIFA, José Roberto, AZEVEDO, Tarik Rezende de. Os climas na cidade de São Paulo. São Paulo: Próreitoria de cultura e extensão universitário, 2001, 199p.

TRICART, J. Ecodinâmica. Rio de Janeiro: IBGE: Supren. 1977

TRICART, J. Paysage et ecologie. Rev. Geomorph. Dynam, XXVIII (1):81-95, Paris, 1979.

VARGAS, R. R.; SAAD, A. R.; DALMAS, F. B.; ROSA, A.; ARRUDA, R. O. M.; MESQUITA, M. V. \& ANDRADE, M. R. M. Water Quality Assessment in the Córrego Taquara do Reino Hydrographic Basin, Guarulhos Municipality (São Paulo State - 
Brazil): Effects of Environmental Degradation. Anuário do Instituto de Geociências UFRJ ISSN 0101-9759 e-ISSN 1982-3908 - Vol. 38 - 2 / 2015 p. 137-144

VARNES, D. J. Slope movement types and processes. In: SCHUSTER \& KRIZEK. Landslides analysis and control. National Academy of Sciences, Washington, 1978, p. 11-33

ZÊZERE, J.L. Dinâmica de vertentes e riscos geomorfológicos. Centro de estudos Geográficos, Relatório n 41, Lisboa, 2005 
Anexo 1. Zona especial de proteção e desenvolvimento sustentável ZPDS - 2




